
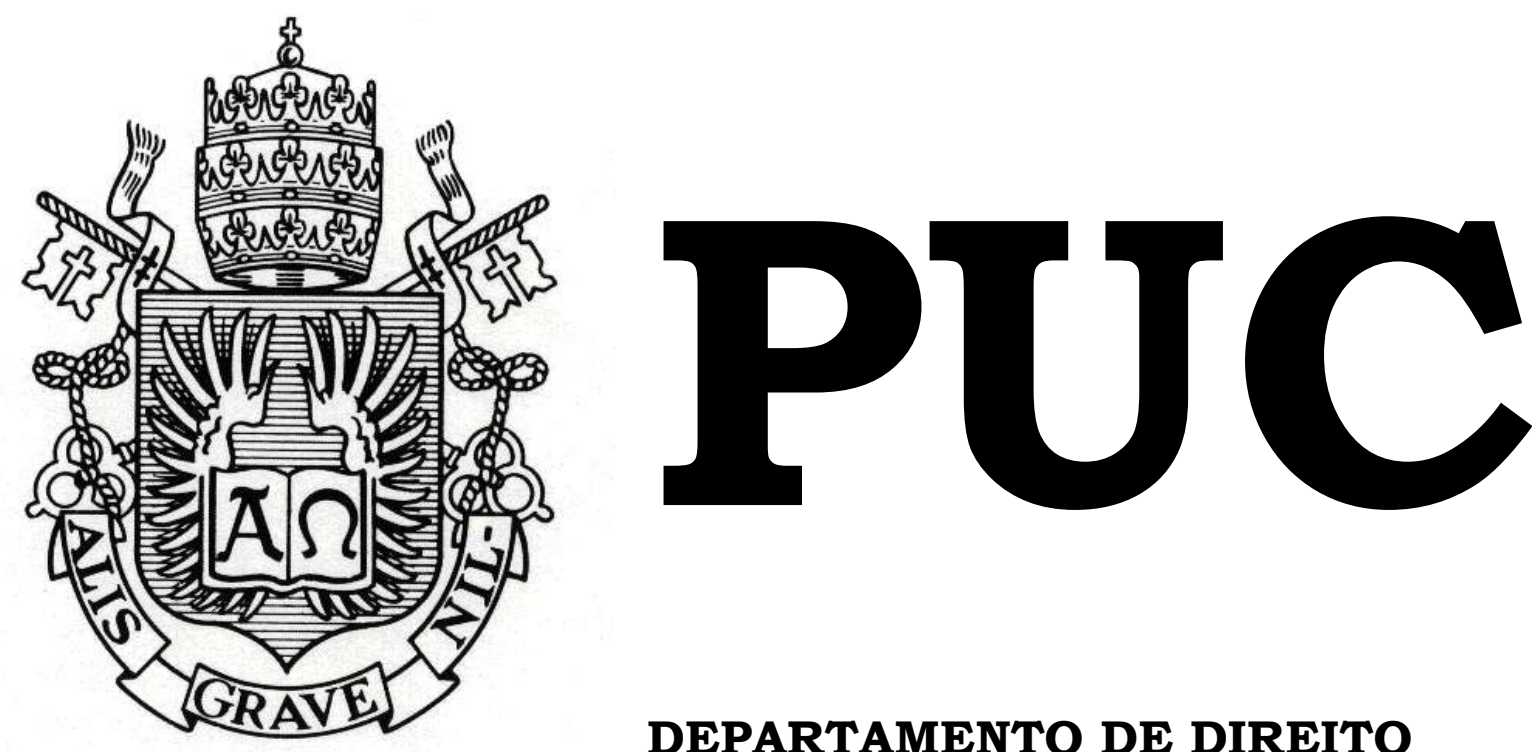

DEPARTAMENTO DE DIREITO

REGULAÇÃO DA MÍdIA E LIBERDADE DE EXPRESSÃO: UMA ANÁLISE DA EXPERIÊNCIA ALEMÃ E AUSTRALIANA

por

CAROLINA MONTEIRO DE CASTRO SILVEIRA

ORIENTADOR: FÁBIO CARVALHO LEITE

2016.2

PONTIFÍCIA UNIVERSIDADE CATÓLICA DO RIO DE JANEIRO

RUA MARQUÊS DE SÃO VICENTE, 225 - CEP 22453-900

RIO DE JANEIRO - BRASIL 


\section{REGULAÇÃO DA MÍDIA E LIBERDADE DE EXPRESSÃO: UMA ANÁLISE DA EXPERIÊNCIA ALEMÃ E AUSTRALIANA}

por

CAROLINA MONTEIRO DE CASTRO SILVEIRA

Monografia apresentada ao

Departamento de Direito da Pontificia Universidade Católica do Rio de Janeiro (PUC-Rio) para a obtenção do Título de Bacharel em Direito.

Orientador(a): Fábio Carvalho Leite 


\section{Agradecimentos}

Agradeço ao meu orientador Prof. Fábio Carvalho Leite pelo incentivo e presteza no auxílio às atividades, pelos anos de PIBIC, pelas reuniões, pelos conselhos e correções que muito me fizeram crescer e aprender. Os seus ensinamentos foram fundamentais na elaboração deste trabalho.

Agradeço aos demais professores da PUC-Rio, que foram corresponsáveis por todo o aprimoramento intelectual que a faculdade de direito proporcionou. $\mathrm{O}$ corpo docente possibilitou muitas visões além dos livros, muitas inspirações e reflexões que tornaram a graduação completa.

À PUC-Rio, que proporcionou estrutura e profissionais fantásticos, sem os quais a graduação não teria sido tão excepcional. Intercâmbios, experiências e prêmios que a PUC-Rio me concedeu e que formaram o que sou hoje. Agradeço também à Vice-Reitoria Comunitária pela bolsa de estudos, que possibilitou que eu me formasse nesta instituição de ensino excelente.

À Patrícia Spínola e Thiago Spínola, que forneceram o endereço na Austrália, sem o qual jamais poderíamos ter realizado o experimento com a autoridade reguladora da mídia australiana.

Por fim, aos amigos e familiares que sempre me apoiaram nesses cinco bons anos de faculdade de direito e os tornaram mais leves e divertidos. 
Resumo: A Austrália e a Alemanha são países que reconhecem o papel da mídia de promotor e garantidor da livre formação de opinião, bem como possuem em seus ordenamentos jurídicos meios que promovem a pluralidade de informações e de perspectivas. O presente estudo buscou investigar o funcionamento do sistema regulatório midiático australiano e alemão na prática, a partir de análise de decisões das suas autoridades reguladoras, seus tribunais administrativos e do próprio judiciário no que tange às interferências estatais na programação das emissoras comerciais do país, tendo como objetivo analisar como os referidos países lidam com a regulação da radiodifusão e a garantia da liberdade de expressão.

Palavras-chave: Regulação da mídia. Radiodifusão. Liberdade de Expressão. Austrália. Alemanha. Autoridade reguladora da mídia. Emissoras comerciais. Programação. Interferência estatal. Controle de conteúdo. Regulação conteudística. 


\section{Sumário}

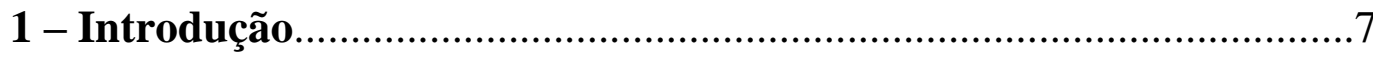

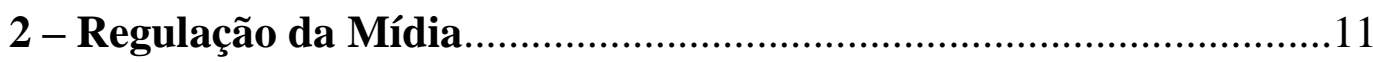

2.1 - Aspectos econômicos e democráticos da regulação da mídia.....15

(A) Regulação econômica da mídia.................................................15

(B) Propósitos econômicos da regulação da radiodifusão...............19

(C) Propósitos democráticos da regulação da radiodifusão..............20

3 - Legislação aplicável à regulação da radiodifusão na Alemanha e na

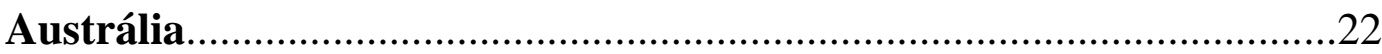

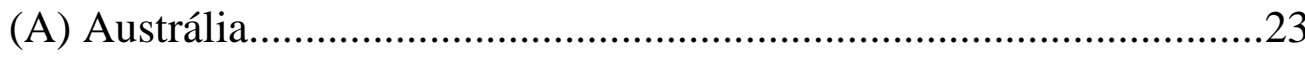

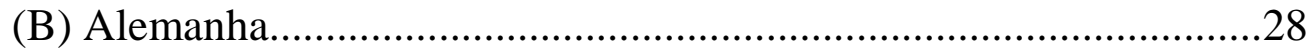

4 - Autoridades reguladoras da mídia.....................................................32

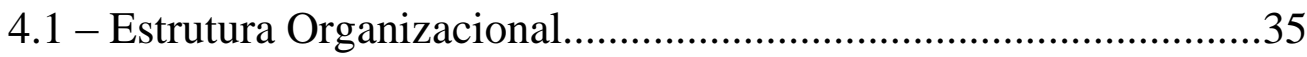

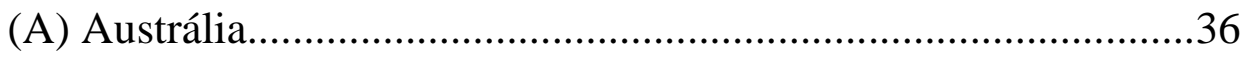

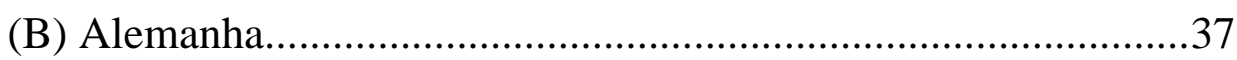

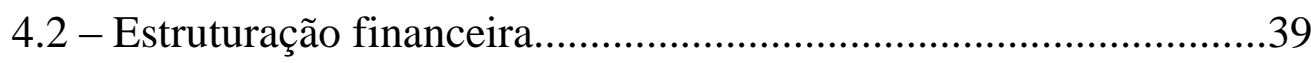

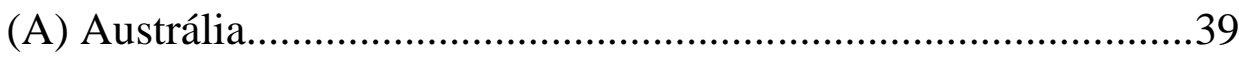

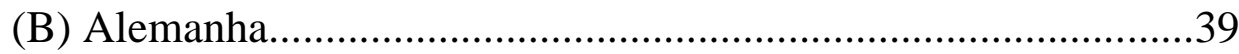

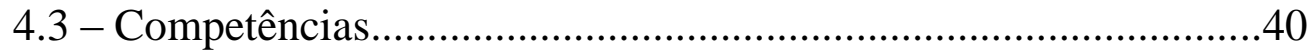

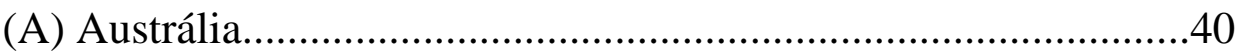

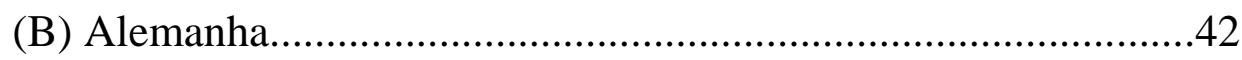

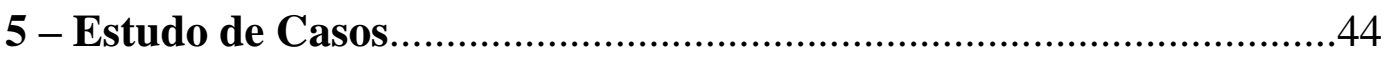

5.1 - Panorama Geral dos casos..........................................................

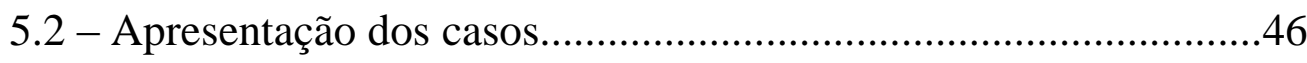

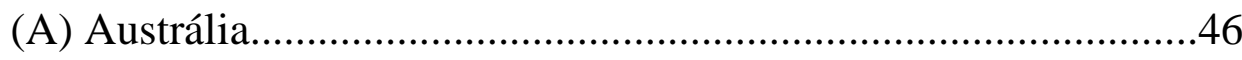

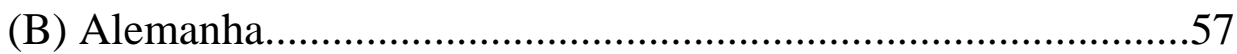


6 - Descrição dos experimentos realizados..............................................64

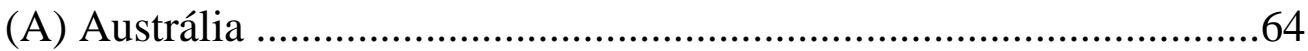

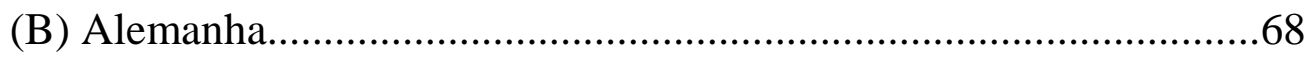

7 - Conclusão

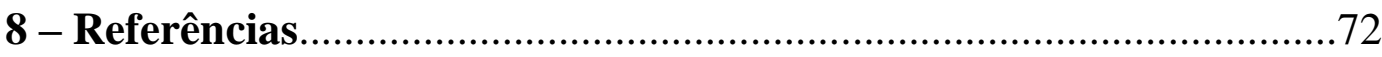

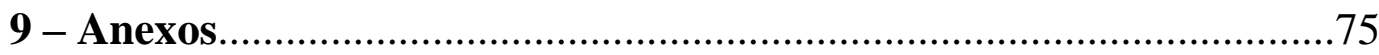

Anexo I - Tabela de Casos Austrália.....................................................75

Anexo II - Tabela de casos Alemanha..................................................... 85

Anexo III - Reclamação à emissora - Austrália......................................88

Anexo IV - Resposta da emissora - Austrália......................................89

Anexo V - Resposta da ACMA.........................................................91

Anexo VI - Troca de e-mails - Alemanha..........................................92 


\section{Lista de tabelas e abreviações}

Tabela 1 - Mudanças na legislação australiana ..................................... 28

Tabela 2 - Regras sobre denúncias à ACMA ...................................... 41

Imagem 1 - Estrutura organizacional da ACMA ................................. 37

Imagem 2 - Estrutura organizacional da Medienanstalten ..................... 39

ACMA - Australian Communications and Media Authority

BSA - Broadcasting Services Act 1992

CSA - Commonwealth Broadcasting Association

FCC - Federal Communications Commission

FSK - Freiwillige Selbstkontrolle der Filmirtschaft

KEK - Kommission zur Ermittlung der Konzentration im Medienbereich

KJM - Kommission Jugendmedienschutz

MABB - Medienanstalt Berlin Brandenburg

UNESCO - Organização das Nações Unidas para Educação, Ciência e Cultura.

ZAC - Kommission fuer Zulassung und Aufsicht 


\section{1 - Introdução}

A ideia de regulação dos meios de comunicação no Brasil, após a promulgação da Constituição de 1988, sempre enfrentou dificuldades e resistência, sendo possível a identificação de alguns obstáculos, quais sejam (i) a experiência histórica de censura no período que antecedeu a promulgação da Constituição de 1988; (ii) o interesse na manutenção do status quo pelos que dele se beneficiam, seja porque conduzem a programação nos meios de comunicação, seja porque com ela se identificam (ideologicamente); (iii) a defesa da liberdade de expressão como um princípio que necessariamente exclui o controle ou a regulação estatal; e (iv) o receio em relação ao controle por conta da indefinição e imprecisão dos limites à liberdade de expressão ${ }^{1}$.

É evidente que a regulação dos meios de comunicação, principalmente quando se trata de uma regulação conteudística, gera debates no mundo todo. Todavia, assumindo como premissa que a democracia se enraíza em ambientes dotados de diversidade de ideias, diálogo e diferenças regionais, inúmeros países democráticos demonstram uma preocupação geral em garantir o direito fundamental à liberdade de expressão e especificar os limites ao exercício de tal direito, procurando um equilíbrio entre o seu exercício e o fomento de sistemas midiáticos mais plurais.

No Brasil, entretanto, pudemos observar, no âmbito dos estudos em desenvolvimento no Núcleo de Estudos Constitucionais da PUC-Rio, que o debate sobre limites à liberdade de expressão é muito raso e, apenas a menção ao tema da regulação da mídia gera uma ideia de censura, de restrição à liberdade de imprensa, ideias estas muitas vezes embasadas em argumentos pouco sofisticados.

Resolvemos, então, investigar como o referido tema é tratado em outros países do mundo. Importante mencionar que o objetivo do presente

\footnotetext{
${ }^{1}$ LEITE, F. C. . Regulação dos meios de comunicação e o desafio do controle de conteúdo: dificuldades no Brasil e algumas contribuições da Alemanha. In: Bello, E.; Ribeiro, S.M.. (Org.). Democracia e meios de comunicação: pluralismo, liberdade de expressão e informação. 1ed.Rio de Janeiro: Lumen Juris, 2016.
} 
trabalho não é realizar uma comparação de sistemas regulatórios da mídia ao redor do mundo, mas de investigar os sistemas alemão e australiano, para fins de introduzir, no debate jurídico e social nacional, o assunto, uma vez que, hoje, pouco se debate acerca da regulamentação da mídia no Brasil, principalmente no que tange à radiodifusão.

Reconhecendo o potencial transformador da indústria da radiodifusão e o pouco espaço no debate jurídico e social nacional dedicado ao debate de sua regulamentação, apesar da expansão das discussões sobre o tema no exterior, o presente trabalho visa auxiliar na introdução deste assunto no país, fornecendo subsídios para que outros juristas e personagens da sociedade civil possam produzir seus próprios trabalhos acerca do tema.

Para a realização do presente trabalho, em primeiro lugar, delineamos um panorama geral, identificando os países os quais possuíam autoridades reguladoras da radiodifusão. Neste caso, o procedimento inicial foi a procura de entidades de regulação midiática através dos portais online dos próprios organismos, bem como a análise de artigos e pesquisas realizadas sobre o tema da regulação da mídia. O resultado foi a informação de que existem autoridades reguladoras da mídia em 49 países, distribuídos dispersamente ao redor do mundo.

Posteriormente, identificamos as principais características e iniciamos o estudo de casos gerais envolvendo as autoridades reguladoras de países membros da União Europeia, quando decidimos iniciar a primeira pesquisa acerca da Alemanha. Após esse primeiro estudo, buscamos analisar casos de países fora da União Europeia.

A escolha da Austrália e da Alemanha para darmos continuidade ao trabalho investigativo se deu, dentre outros fatores: (i) similaridades com o Brasil quanto à forma de governo e forma de Estado (república federativa); (ii) a Austrália passou recentemente por uma revisão completa em seu cenário regulatório no que tange à radiodifusão, tendo inúmeros debates recentes acerca do tema; (iii) a Alemanha é considerada líder mundial no tema da regulação midiática e é considerada um país de imprensa livre, de 
acordo com o índice do "Reporters Without Borders Press Freedom", assim como a Austrália; (iv) a Alemanha há 30 anos debate sobre o tema tendo, inclusive, oito decisões históricas da Suprema Corte acerca do melhor sistema que deveria ser adotado para regulação da radiodifusão do país; (v) a Austrália é considerada um dos países com maior concentração dos meios de comunicação, de forma similar ao oligopólio brasileiro; (vi) assim como no Brasil, Austrália e Alemanha asseguram a liberdade de expressão e a liberdade de imprensa em sua Lei Maior; (vii) Alemanha e Austrália possuem regras obrigacionais acerca de medidas positivas para assegurar pluralismo e independência da radiodifusão; e (viii) habilidades para conduzir a pesquisa (por exemplo, barreiras da linguagem e disponibilidade de material).

Em seguida à escolha dos países (Austrália e Alemanha), optamos por analisar os casos que envolvessem especificamente emissoras privadas de radiodifusão, uma vez que as emissoras públicas possuem um sistema de regulação mais particular, com mais imposições estatais acerca da programação. Além disso, o Brasil não possui um sistema diversificado e desenvolvido de emissoras públicas como a Austrália e a Alemanha, motivo pelo qual nos limitamos à investigação dos casos abarcando emissoras comerciais.

Iniciaremos o presente trabalho com uma análise geral da regulação da mídia, apresentando seus aspectos econômicos e democráticos. Importante mencionar que não pretendemos, entretanto, discutir detalhadamente a ideia da regulação da radiodifusão, eis que assumimos como premissa que algum grau de regulação é essencial numa sociedade democrática. A simples constatação de que formas de regulação são adotadas em diversos países democráticos já seria bastante sugestiva.

\footnotetext{
2 O índice do "Reporters Without Borders Press Freedom" pode ser acessado em http://en.rsf.org/press-freedom-index-2011-2015,1043.html e fornece um ranking mundial anualmente, baseado em critérios como o controle e propriedade dos instrumentos da mídia; censura e auto-regulação dos meios de comunicação; pluralidade de informações; e violência e tortura com jornalistas.
} 
Posteriormente, apresentaremos um panorama geral do sistema regulatório de radiodifusão da Austrália e da Alemanha, com a finalidade de proporcionar ao leitor uma visão de como cada um desses países lida com a regulação da mídia, bem como suas principais regras.

Pretendemos ainda expor sucintamente a transformação legislativa do setor pela qual a Austrália está passando neste momento, principalmente no que tange às regras concernentes à concentração dos meios de comunicação. Entender as características fundamentais do sistema regulatório de cada país será essencial para uma análise mais profunda dos casos que serão apresentados mais adiante.

Após abordamos as legislações de ambos os países, realizaremos um estudo sucinto acerca das autoridades reguladoras da mídia em ambos os países, explicitando as estruturas organizacionais e financeiras de cada uma delas, bem como suas competências no âmbito dos respectivos sistemas regulatórios. Neste capítulo, procuraremos expor o conceito do termo autoridade reguladora da mídia, além de explicitar sua importância para o desenvolvimento de uma indústria de radiodifusão plural e democrática.

Posteriormente, apresentaremos os casos estudados em ambos os países envolvendo regulação conteudística da radiodifusão. Acreditamos ser de imensa importância, para um entendimento mais profundo acerca do sistema regulatório de cada país, analisar não só a legislação pertinente, mas como cada país lida com as situações concretas, até para sabermos qual é a interpretação dada à legislação aplicável. Além disso, com o estudo de casos, pudemos ainda analisar quais temas são mais frequentes, quais tipos de argumentos são apresentados pelas autoridades reguladoras, se há parâmetros gerais estabelecidos nas decisões (ou se tudo é decidido casuisticamente), se há consenso quanto às decisões tomadas administrativamente (ou se inúmeras revisões judiciais são pleiteadas).

Para a análise de casos, apresentaremos inicialmente um panorama geral com a indicação dos dados encontrados, quais sejam, número de casos 
investigados, principais matérias, número de decisões que consideraram que houve violação da lei, número de casos que chegaram à esfera judicial. Posteriormente, exporemos de forma detalhada quatro casos da Alemanha e cinco casos da Austrália, indicando ainda os argumentos utilizados nas decisões dos referidos casos.

Finalmente, o último capítulo trata do experimento que resolvemos fazer, tanto na Alemanha, quanto na Austrália. Com o intuito de testarmos as autoridades reguladoras de ambos os países e entendermos realmente como uma investigação funciona na prática, isto é, como pode o telespectador realizar a reclamação, quanto tempo demora para uma resposta, e se as emissoras se envolvem no processo e dialogam, resolvemos assistir aos programas de televisão de ambos os países e enviar nossas próprias reclamações para experimentarmos como realmente funciona o sistema de cada país.

Os experimentos foram realizados no âmbito do grupo de pesquisa sobre o tema regulação dos meios de comunicação - e que integra as pesquisas em desenvolvimento no Núcleo de Estudos Constitucionais da PUC-Rio. No caso da Alemanha, o experimento foi desenvolvido em parceria com a acadêmica Renata Leal (bolsista de iniciação científica da PUC-Rio).

Como mencionamos, o debate no Brasil acerca da regulação da radiodifusão ainda é muito raso, diferente dos países investigados, os quais possuem um debate sobre o tema em grau mais elevado de sofisticação. Pretendemos, portanto, contribuir com a experiência alemã e australiana, para fins de elevar o nível e aumentar o espaço para o debate em nosso país.

\section{2 - Regulação da Mídia}

O mundo foi literalmente capturado pelo rádio e pela televisão, poderosos meios de comunicação dotados de tremendo potencial de 
informar, entreter e educar. A radiodifusão impacta profundamente a forma de viver e pensar de cada um de nós, com reflexos na cultura, na educação, nas ideias e na formação pessoal dos indivíduos, constituindo uma importante parte de nossas vidas, de tal forma que, é difícil dizer se constitui um luxo ou uma necessidade. No Brasil, a título de exemplo, de acordo com os dados fornecidos pelo Instituto Brasileiro de Geografia e Estatística - IBGE, 93,7\% dos domicílios possuem aparelhos de televisão e $81,4 \%$ aparelhos de rádio ${ }^{3}$.

Na medida em que a relação com os meios de comunicação se intensifica e a produção em massa torna-se evidente, surge a preocupação geral de garantir uma mídia livre, independente, plural e diversificada, preocupação esta que passa a se fixar como o ideal a ser alcançado para que o direito à liberdade de buscar, difundir e receber informações possa ser realizado em sua plenitude.

Por outro lado, ao mesmo tempo que a mídia constitui um importante meio de transmitir informações, educar e democratizar, começam a surgir questionamentos direcionados ao potencial que o setor de radiodifusão tem em criar condições manipulativas e gerar tendências nas preferências e opiniões da população sobre determinado tema, momento em que a questão começa a envolver outros temas, como o da liberdade de expressão.

Em relação às liberdades e aos direitos fundamentais em geral, pode-se dizer que, até o final do século XX, o Estado era tido como o principal adversário das garantias constitucionais. A partir do momento em que a mídia influi diretamente na vida dos particulares, as restrições promovidas pelo Estado na capacidade discursiva dos indivíduos continuam sendo vistas como um risco, mas a teoria constitucional começa a reconhecer que o desrespeito aos direitos fundamentais podese dar não apenas pela ação estatal, mas também pelos atores do setor

\footnotetext{
${ }^{3}$ Informação disponível em <ibge.gov.br> acesso em 21.06.2015.
} 
privado, os quais interferem de forma ilegítima sobre a liberdade constitucionalmente garantida aos indivíduos.

Neste sentido, entes privados começam também a ser vistos como potenciais violadores de direitos fundamentais e o legislador passa a ter a tarefa de criar mecanismos dirigidos à proteção desses direitos. Nas palavras de Alexandre Sankievicz:

Para a democracia coparticipativa, a liberdade, corretamente entendida, consiste não apenas na garantia da livre escolha, mas na possibilidade de o indivíduo ter suas próprias crenças e preferências, formadas a partir de condições apropriadas [...] constitui a possibilidade de formar suas preferências ou mesmo mudá-las após ser exposto a um número suficiente de informações e diferentes opiniões sobre um mesmo tema. Não é assegurada a liberdade de expressão se as preferências das pessoas são manipuladas. ${ }^{4}$

Diante deste cenário, países começaram a introduzir em seus ordenamentos jurídicos a garantia do direito fundamental à pluralidade de informações, para fins de assegurar a livre formação de opinião. A Convenção Europeia sobre Televisão Transfronteiras dispõe: "a emissora deve garantir que os noticiários apresentem os fatos e eventos de forma justa, e que incentive a livre formação de opinião." 5 Já o Código de Ética de Emissoras Canadenses assegura que "a principal finalidade da disseminação de notícias em uma democracia é permitir que as pessoas saibam o que está acontecendo, e que entendam os eventos de modo a tirar suas próprias conclusões". ${ }^{6}$ Além disso, os países desenvolveram um sistema regulatório a fim de regulamentar a radiodifusão, através da presença de leis e autoridades reguladoras independentes para aplicá-las.

As agências reguladoras criadas com expertise em setores específicos não são uma novidade, sendo interessante mencionar que a primeira agência reguladora específica da qual se tem conhecimento é a

\footnotetext{
${ }^{4}$ SANKIEVICZ, Alexandre. Liberdade de Expressão e Pluralismo - Perspectivas de Regulação. São Paulo: Saraiva, 2011, p. 40.

5 Artigo 7.3 da Convenção Europeia sobre Televisão Transfronteiras, disponível em $\langle$ http://www.book.coe.int/conv/en/ui/frm/fl32-e.htm>.

${ }^{6}$ Cláusula 5 do Código, disponível em < http://www.cbsc.ca/english/codes/cabethics.
} 
Insterstate Commerce Commission, criada nos Estados Unidos em 1887. Alguns anos depois, inúmeras agências reguladoras foram criadas, entre as quais se encontra a Federal Communications Commission (FCC), responsável pela regulação das comunicações dos Estados Unidos da América nos dias atuais.

A preocupação de grande parte das sociedades atuais é a construção de um ambiente regulatório que equilibre atividade econômica e atividade estatal, fomentando sistemas midiáticos mais livres e diversificados.

Então, por que deve a radiodifusão ser regulamentada? É o que pretendemos abordar neste capítulo, analisando os objetivos econômicos e democráticos da regulação.

Antes de adentrarmos ao tema, cabe, porém, fazer uma breve introdução das formas de regulação do setor de radiodifusão mais comuns nos diferentes países do mundo.

A regulação, no sentido original da palavra, normalmente refere-se a um processo arbitrário sob o domínio do Estado, geralmente centrada em um órgão regulador (que pode ser mais ou menos independente) e este órgão toma decisões através de um corpo especializado naquela determinada matéria, devido a sua especificidade. Tal conceito tradicional diz respeito a regulação estatal propriamente dita. Basicamente, há outras duas formas de regulação adotadas, quais sejam: (i) auto-regulação; e (ii) co-regulação.

Como o próprio nome já diz, a auto-regulação é o meio pelo qual o próprio setor se regula, através de códigos de prática e de ética. Podem ser criados conselhos e comissões, as quais os membros - as emissoras de radiodifusão - se obrigariam a seguir padrões de conduta, sob pena de multa ou demais consequências previstas. Na Suécia, por exemplo, há um sistema de auto-regulação voluntária da mídia - mas 
que se equilibra sobre o alicerce de um sólido conjunto de normas de conduta, e leva em conta a voz do público. Não há uma legislação específica para regular a imprensa: o que rege o sistema é um robusto código de ética. ${ }^{?}$

O sistema de co-regulação envolve o Estado, as autoridades reguladoras independentes, a indústria, comissões e conselhos de autoregulação e grupos da sociedade civil. É um sistema que busca descentralizar a regulação estatal criando mecanismos de co-gestão e negociação entre governo e indústria acerca das regras para aquele setor. A co-regulação é uma forma de regulamentação que vem crescendo ao redor do mundo e é cada vez mais utilizada em diferentes países e, como observaremos mais adiante, é adotada hoje na Austrália.

\subsection{Aspectos Econômicos e Democráticos da Regulação da Mídia}

\section{(A) Regulação econômica da mídia}

A regulação econômica da mídia aborda primordialmente o controle da concentração da radiodifusão (como oligopólios e monopólios), ideal para estimular a diversidade de programação. Outra questão tratada pela regulação econômica da mídia é a regionalização da produção. No Brasil, por exemplo, grandes emissoras possuem concessões apenas para alguns municípios, mas se organizam em redes pelo Brasil por meio de outras emissoras, afiliadas, as quais, embora sejam emissoras regionais, acabam transmitindo toda a programação das grandes emissoras das quais são afiliadas.

Por um lado, uma estrutura regulatória financiada diretamente pelo Estado, com um monopólio dos meios de comunicação por parte do Estado, seria extremamente perigosa para a pluralidade de opinião e

7 WALlin, Claudia. "Como a mídia é regulada na Suécia”. Disponível em http://www.diariodocentrodomundo.com.br/como-a-midia-e-regulada-na-suecia/. Acesso em 03/06/2016. 
liberdade de expressão, na medida em que propiciaria uma concentração política em detrimento das possibilidades de críticas dos órgãos públicos governantes, que controlariam a radiodifusão de forma que nem toda informação fosse transmitida. Neste cenário, seria difícil distinguir a esfera do livre pensamento daquela imposta pelo direcionamento estatal ${ }^{8}$. Por tal motivo, o mercado é visto como maior assegurador da liberdade de expressão, na medida em que se ampara em princípios essencialmente ligados à finalidade das liberdades comunicativas, como a autonomia individual, a voluntariedade, a livre circulação de ideias e a descentralização.

Por outro lado, é evidente que há falhas também no sistema financiado pela iniciativa privada, que igualmente pode propiciar a concentração da informação. Um sistema que tão somente depende da dinâmica do mercado para o acesso à radiodifusão apresenta igualmente problemas para a efetivação da democracia coparticipativa, e é nesse ponto que se faz necessária a regulação econômica da mídia, para fins de propiciar a pluralidade de informação e, consequentemente, a livre formação de opinião.

Há três tipos de concentração da radiodifusão: horizontal, vertical e diagonal. A primeira refere-se ao oligopólio ou monopólio produzido dentro de uma área industrial e, para medir esse nível de concentração horizontal são utilizados dois grandes modelos, quais sejam (i) índice de audiência ou porcentagem de espectadores de determinado canal de rádio ou televisão (como veremos mais a frente, a legislação alemã utiliza tal método e entende que um canal possui posição dominante capaz de influenciar a opinião pública de forma excessiva quando atinge $30 \%$ de audiência durante um ano); e (ii) número de concessionárias no mercado da mídia (há países que

\footnotetext{
${ }^{8}$ SANKIEVICZ, Alexandre. Liberdade de Expressão e Pluralismo - Perspectivas de Regulação. São Paulo: Saraiva, 2011, p. 67.
} 
proíbem que uma determinada empresa possua mais que certo número de concessões).

Já a concentração vertical diz respeito à integração das diferentes fases de produção e distribuição, eliminando o trabalho de produtores independentes. Há uma clara premissa de que não adianta multiplicar o número dos proprietários de televisão e rádio se somente poucas empresas se encarregam da produção e distribuição de conteúdo.

Por fim, a concentração diagonal, também denominada propriedade cruzada, é aquela em que há propriedade de diferentes tipos de mídia (jornais, televisão, revistas) por parte de um mesmo grupo.

Em diversos países democráticos há métodos para prevenir e controlar a concentração dos meios de comunicação, com regras específicas tanto no setor de radiodifusão como no setor midiático como um todo. Frisa-se que no Brasil há apenas limitação quanto à outorga de radiodifusão por empresa, não havendo regras específicas sobre propriedade cruzada ou limites para o percentual máximo de audiência.

Dentre tais métodos de prevenção da concentração da mídia, pode-se citar a limitação do número de estações de rádio ou televisão de que pode uma empresa ou um grupo ser proprietário, limitação no percentual de audiência de uma determinada emissora e proibição da propriedade cruzada.

A título de exemplo, a legislação alemã, como acima mencionado, estabelece um limite máximo de $30 \%$ de audiência no período de um ano para uma emissora. Caso a emissora ultrapasse tal limite, serão negociados com a autoridade reguladora específica para a 
concentração da mídia ${ }^{9}$, meios para que a emissora retorne ao limite máximo permitido de audiência, como, por exemplo, a empresa poderá desistir de sua participação em empresas de radiodifusão até que a quota de audiência atinja o limite permitido.

O sistema francês adota um modelo mais complexo, mesclando regras de limitação à propriedade com limitação de audiência. A lei francesa limita o número de ações que um indivíduo ou empresa pode ser titular em diferentes canais de televisão nacionais, de modo que uma pessoa ou empresa não pode possuir mais de $49 \%$ do capital ou direitos de voto de um canal de televisão cuja audiência média anual é maior do que $8 \%$ da audiência total de serviços de televisão ${ }^{10}$. A legislação francesa estipula ainda que nenhuma pessoa ou entidade jurídica pode possuir mais de uma licença nacional para televisão terrestre ${ }^{11}$.

A legislação norte-americana impede que as estações de rádio ou televisão de um único proprietário alcancem mais de 39\% da rede nacional de televisão ${ }^{12}$, além de proibir fusões entre as chamadas "Top Quatro" emissoras (ABC, NBC, CBS, FOX). No Japão, os proprietários de meios de comunicação têm permissão para possuir uma única estação de televisão.

No que tange à regulação da mídia na Austrália, a legislação estabelece que cada capital estatal deve possuir, ao menos, cinco emissoras que não pertençam ao mesmo grupo econômico e em relação às zonas rurais o referido número diminui para quatro. No entanto, a

\footnotetext{
${ }^{9}$ KEK - Kommission zur Ermittlung der Konzentration im Medienbereich

${ }^{10}$ Art. 39, I "Une même personne physique ou morale agissant seule ou de concert ne peut détenir, directement ou indirectement, plus de $49 \%$ du capital ou des droits de vote d'une société titulaire d'une autorisation relative à un service national de télévision diffusé par voie hertzienne terrestre dont l'audience moyenne annuelle par un réseau de communications électroniques au sens $d u 2^{\circ}$ de l'article L. 32 du code des postes et des communications électroniques, tant en mode analogique qu'en mode numérique, dépasse $8 \%$ de l'audience totale des services de télévision".

${ }^{11} \mathrm{Art}, 41$. "Nul ne peut être titulaire de deux autorisations relatives chacune à un service national de télévision diffusé par voie hertzienne terrestre. Cette disposition ne s'applique pas aux services diffusés en télévision mobile personnelle.". (Loi n 86-1067 du 30 septembre 1986 relative à la liberté de communication)

${ }^{12}$ National Television Ownership Limit
} 
regulação australiana é alvo de críticas no que tange à limitação da propriedade cruzada, uma vez que a legislação autoriza que uma única empresa de meios de comunicação possa ser proprietária de uma estação de televisão, duas estações de rádio e um jornal no mesmo mercado geográfico. Apesar de haver limites, há muitas críticas de que tais limites não seriam suficientes para assegurar a pluralidade na Austrália, país com uma das maiores concentrações de mídia do mundo.

Como se pode perceber, democracias do mundo todo possuem regras referentes à regulação econômica da mídia, muito porque se entende que deve ser assegurada a diversidade de perspectivas e de programação para a formação livre de opinião, características importantes para um setor de radiodifusão mais democrático.

\section{(B) Propósitos econômicos da regulação da radiodifusão}

As finalidades econômicas da regulação da radiodifusão são muitas e vão além da garantia à ampla concorrência e do controle da concentração da mídia já abordado acima, tendo outros aspectos relevantes, como os indicados abaixo.

i) Aplicação de tratados internacionais: por exemplo, os membros da União Europeia estão vinculados por uma diretiva (Televisão sem fronteiras) que permite a livre circulação dos serviços de radiodifusão, desde que todos eles cumpram os mesmos padrões mínimos básicos de regulação de conteúdo;

ii) Apoio dos setores produtivos nacionais: muitos países definem cotas para a quantidade de produção original (que é a programação feita no interior do país ou dentro de uma zona de comércio) e também cotas para produções realizadas por produtores independentes.

iii) Meio de equilibrar o investimento estrangeiro com a promoção das indústrias nacionais: uma decisão-chave que muitas nações precisam tomar é se devem ou não permitir 
investidores estrangeiros na indústria nacional de radiodifusão. A liberalização do investimento estrangeiro sem acordos recíprocos pode levar a muita controvérsia interna e debate.

iv) Promoção de novas tecnologias: por exemplo, estabelecendo incentivos na legislação para as emissoras investirem na tecnologia digital, o que pode resultar em trabalho inovador e pioneiro neste campo.

v) Limitação da publicidade: a limitação pode ocasionar um aumento no preço do tempo de publicidade.

\section{(C) Propósitos democráticos da regulação da radiodifusão}

É importante para as sociedades democráticas a existência de uma ampla gama de meios independentes e autônomos de comunicação, capazes de refletir a diversidade de ideias e opiniões.

Uma das questões fundamentais para os legisladores é determinar o equilíbrio entre os direitos potencialmente conflitantes das emissoras, da sociedade representada pelo Estado e dos indivíduos. Os principais fatores relacionados aos fins democráticos da radiodifusão e que costumam ser considerados na inclusão das legislações pertinentes estão indicados abaixo.

i) O direito de resposta e regras de equidade: dado o poder da radiodifusão, é geralmente considerada adequada para as empresas do setor, a obrigação do oferecimento de um direito imediato de resposta a qualquer pessoa ou organização que tenha sido tratada de forma injusta em um programa. Pedidos de desculpas também costumam ser abordados por algumas legislações.

ii) Notícias precisas e imparciais: algumas legislações exigem a imparcialidade e exatidão das notícias transmitidas, 
dado o poder de persuasão do setor da radiodifusão. Alguns países, por exemplo, os membros da União Europeia, exigem a imparcialidade no que tange a programas de notícias. Este não é o caso em outros como, por exemplo, nos EUA, onde o viés editorial da emissora pode filtrar determinadas informações.

iii) Obrigações gerais de imparcialidade: em muitos países é considerado aceitável um grau de perspectiva editorial para afetar a programação geral da emissora, quando se trata de notícias. No entanto, no Reino Unido, todas as notícias e outros programas que tratem de questões controversas devem ser imparciais, o que não significa que os pontos de vista e opiniões não podem ser exibidos, mas que cabe à emissora garantir que os pontos de vista opostos sejam ouvidos.

iv) Imperativos culturais: alguns governos estão cada vez mais preocupados com os efeitos da globalização na cultura local, muitas vezes citando a propagação da televisão norteamericana como causa de uma perda de identidade local. Alguns países, portanto, procuraram impor linguagem e quotas de produção originais na sua transmissão (por exemplo, Canadá e França têm ambos os requisitos estabelecidos para a programação de língua francesa). Isto pode ter a vantagem adicional de estimular a produção local, mas cuidados devem ser tomados para que não sejam fixadas cotas artificialmente elevadas e que não podem realisticamente ser satisfeitas (por exemplo, a Croácia tem procurado definir uma cota de produção original de $50 \%$, só que o país não tem praticamente nenhum setor de produção de televisão nacional).

v) Regras que impedem a discriminação: garantia de que os programas não transmitam material discriminatório - incluindo os pontos de vista dos entrevistados ou convidados do programa - por exemplo, por motivos de raça, nacionalidade, religião ou sexo. 
vi) Regras especiais sobre a radiodifusão religiosa: a religião é outra área sensível e que exige regras especiais para garantir que o respeito seja dado a todas as crenças religiosas e para coibir qualquer tipo de intolerância religiosa.

vii) Regulação independente: para garantir a liberdade dos meios de comunicação e, ao mesmo tempo, o equilíbrio entre a liberdade e outros direitos e interesses legítimos. Talvez o mais importante meio para assegurar a democracia coparticipativa na radiodifusão seja a criação de entidades reguladoras independentes para o setor. Mesmo em pequenas jurisdições, onde a única emissora é financiada pelo Estado e os orçamentos são limitados, uma entidade independente do Estado é fundamental para preservar o direito à liberdade de expressão.

Desta forma, a regulação da radiodifusão apresenta um papel fundamental para garantir todos os objetivos acima expostos (econômicos e democráticos) e, principalmente, para assegurar a liberdade de expressão, a livre formação de opinião e a pluralidade de informações. A seguir, analisaremos mais especificamente a legislação aplicável à regulação da radiodifusão na Alemanha e na Austrália.

\section{3 - Legislação aplicável à regulação da radiodifusão na Alemanha e na Austrália}

No presente capítulo, pretendemos apresentar um panorama geral do sistema regulatório de radiodifusão da Austrália e da Alemanha, com a finalidade de proporcionar ao leitor uma visão de como cada um desses países lida com a regulação da mídia, bem como suas principais regras.

Pretendemos ainda expor sucintamente a transformação legislativa do setor pela qual a Austrália está passando neste momento, principalmente no que tange às regras concernentes à concentração dos meios de comunicação. 
Entender as características fundamentais do sistema regulatório de cada país será essencial para uma análise mais profunda dos casos que serão apresentados mais adiante.

\section{A) Austrália}

O sistema regulatório da radiodifusão existente na Austrália é baseado na co-regulação, isto é, envolve tanto o Estado, quanto as autoridades reguladoras independentes, a indústria, as comissões, os conselhos de auto-regulação e grupos da sociedade civil. É um sistema que busca descentralizar a regulação estatal, criando mecanismos de co-gestão e negociação entre governo e indústria acerca das regras para aquele setor.

Inicialmente cumpre esclarecer que a regulação da mídia na Austrália gira em torno de 4 (quatro) leis principais, quais sejam, o Broadcasting Services Act 1992, o Telecommunications Act 1997, o Telecommunications (Consumer Protection and Service Standards) Act 1999 e o Radiocommunications Act 1992, sendo importante enfatizar que, como mencionamos acima, a legislação australiana no que concerne à radiodifusão está passando atualmente por uma reforma, a qual será abordada neste capítulo.

Dentre os mecanismos de co-gestão criados, é fundamental mencionar que as principais regras consoantes à regulação de conteúdo no âmbito da radiodifusão na Austrália são estabelecidas pelos Códigos de Práticas, os quais são conjuntos de regras que regulam e orientam o que pode ser transmitido pelas emissoras. Os códigos são desenvolvidos por grupos da indústria de televisão e rádio e também podem abranger outras questões como, por exemplo, o tratamento de denúncias. Eles são revistos regularmente e registrados pela Australian Communications and Media Authority ("ACMA"), autoridade reguladora australiana, a qual será vista mais detalhadamente no próximo capítulo.

Reclamações e denúncias sobre o cumprimento de um Código de Prática devem ser enviadas primeiramente à emissora e serão encaminhadas para a autoridade reguladora caso não haja resposta em 60 (sessenta) dias 
ou caso a resposta não seja satisfatória. Neste sentido, sempre que a questão envolver uma regulação de conteúdo, deve haver um primeiro diálogo entre o telespectador e a emissora, antes de qualquer envolvimento da autoridade reguladora.

O atual Código de Prática da Indústria da Televisão Comercial foi registrado na ACMA em novembro de 2015 e entrou em vigor em $01 / 12 / 2015^{13}$, abrangendo matérias como propaganda e classificação etária, imparcialiade e privacidade em programas de caráter jornalístico, discriminação em razão da idade, cor, sexo, origem étnica, deficiência, raça, religião ou orientação sexual.

No capítulo da exposição e análise dos casos, veremos de forma mais detalhadas as regras estabelecidas pelos códigos de prática, além de podermos compreender como são tais regras aplicadas na prática. No entanto, cabe neste momento citar algumas regras existentes, como as aplicáveis a programas de caráter jornaístico.

Nessas espécies de programas, deverá a emissora: (a) apresentar os elementos de fato com precisão e garantir a diversidade de pontos de vista, de forma que não haja informações deturpardas ${ }^{14}$; (b) ter sensibilidade em transmitir imagens ou entrevistas com parentes em luto ou pessoas que tenham testemunhado ou sobrevivido a um incidente traumático; (c) não transmitir notícias sobre suicídio ou tentativa de suicídio a menos que haja uma razão de interesse público para fazê-lo, e excluir qualquer detalhe do método usado, não incluindo imagens ${ }^{15}$; (d) distinguir claramente a apresentação do fato ocorrido de comentários, opiniões e análises ${ }^{16}$.

Além dos Códigos de Prática e do Broadcasting Services Act 1992 (BSA) (responsável por regular competências da ACMA e questões de

\footnotetext{
13 Commercial Television Industry Code of Practice. Disponível em: http://www.acma.gov.au/ /media/Broadcasting\%20Investigations/Regulation/pdf/Commercial_Te levision_Industry_Code_of_Practice_2015\%20pdf.PDF < Acesso em 28/09/2016.

${ }^{14}$ Commercial Television Industry Code of Practice. Cláusula 3.3.1. Nesse caso, se em até 30 dias da reclamação dirigida à emissora ou à autoridade reguladora for corrigida a informação, não será considerado que houve violação da cláusula 3.3.1.

${ }^{15}$ Commercial Television Industry Code of Practice. Cláusula 3.2.1.

${ }^{16}$ Commercial Television Industry Code of Practice. Cláusula 3.4.1.
} 
licenciamento), a Austrália conta com os chamados standards. Um standard é uma norma de observância obrigatória determinada pela ACMA para aplicar a um determinado setor, onde não existe um código sobre o assunto ou códigos existentes não estão fornecendo garantias comunitárias apropriadas. Por exemplo, quotas de produção de conteúdo australiano e programas infantis na televisão comercial são regulados por essas normas. As emissora têm como condição de sua licença a conformidade com os standards. Reclamações e denúncias sobre o cumprimento dessas normas podem ser feitas diretamente a ACMA, sem necessidade de contatar primeiro a emissora.

Dentre esses standards existentes, é importante citar algumas regras do Children's Television Standards, cujo objetivo é garantir que as crianças tenham acesso a uma variedade de programas de televisão de qualidade, com conteúdos feitos especificamente para esse público infantil, bem como proteger as crianças contra possíveis efeitos nocivos da televisão. O standard estabelece que, a cada ano, as emissoras de televisão devem transmitir: (i) 260 horas de programa designados para menores de 14 anos de idade (programas com classificação C); e (ii) 130 horas para crianças pré-escolares (programas com classificação $P$ ).

A legislação estabelece ainda que programas classificados como $\mathrm{C}$ e $\mathrm{P}$ devem ser projetados especificamente para atender às necessidades e interesses das crianças. A referida norma também é responsável por regulamentar a publicidade infantil, sendo que a publicidade é vedada durante programas dirigidos ao público pré-escolar (classificados pela ACMA como "p") e, podendo-se ainda citar regras como (a) "Nenhuma publicidade pode levar uma criança a acreditar que vencerá ou será superior a outra". (b) "Nenhuma publicidade pode levar uma criança a acreditar que cada pessoa que compra um produto ou serviço para uma criança é mais generosa do que outra".

Além dos códigos de prática e standards, a regulação da radiodifusão na Austrália conta com outra importante ferramenta: a condição de licença das emissoras, que pode aplicar-se a todos os licenciados ou licenciados 
específicos, de acordo com o estabelecido pelo BSA. Por exemplo, emissoras de rádio e televisão estão sujeitas a uma condição de licença proibindo-as de anúncios de difusão de tabaco. De tempos em tempos, a ACMA pode impor uma condição de licença adicional em um licenciado especial, para resolver um problema de compliance.

Como mencionamos, a legislação australiana concernente à regulação da radiodifusão na Austrália passa por uma transformação, principalmente sob a justificativa de que as referidas leis foram elaboradas durante uma era em que o cenário da mídia era dominado por jornais impressos, rádio e televisões comerciais.

Os avanços tecnológicos ao longo dos últimos anos permitem agora que os conteúdos digitais possam ser acessados instantaneamente em qualquer lugar do mundo, por meio de computadores, smartphones ou smart TVs. Essas novas opções mudaram a forma de consumir mídia na Austrália e intensificaram a concorrência entre os meios de comunicação.

Com as reformas, o governo australiano irá revogar duas regras de concentração midiática na Lei de Serviços de Radiodifusão relacionadas à audiência e concentração de mercado, quais sejam: (i) uma pessoa, por si só ou como diretora de uma ou mais companhias não pode exercer o controle de uma emissora de televisão comercial cuja área de licenciamento tenha uma população que exceda $75 \%$ da população da Austrália; e (ii) uma pessoa ou grupo pode apenas controlar 2 (duas) das plataformas de mídia (televisão comercial, rádio comercial, jornais associados)

Além disso, o Governo procura introduzir mudanças que irão proteger a produção de conteúdo de televisão local e regional, bem como o incentivo para que o conteúdo local seja filmado na própria área. Faz parte do pacote ainda outras regras relacionadas à diversidade de programação.

Atualmente, o Governo utiliza um sistema de pontos para assegurar que as comunidades regionais tenham acesso ao conteúdo local, como os noticiários. As regiões de Queensland, Northern New South Wales, Southern New South Wales, Victoria e Tasmania estão sujeitas a obrigações de conteúdo local em que as emissoras devem produzir pelo menos 720 
pontos de conteúdo local por períodos de seis semanas (cada minuto vale um ponto).

Para responder às preocupações de que mudanças nas regras de concentração da mídia poderiam reduzir a quantidade de conteúdo local, a reforma aumentará a quantidade necessária de pontos de conteúdo local para 900, no mesmo período (seis semanas). Estes requisitos serão aplicáveis quando uma mudança no controle de um grupo econômico resultar na situação em que na área de licenciamento do referido grupo a população seja superior a $75 \%$ da população australiana.

Haverá mudanças também nas obrigações de emissoras de televisão que abrangem mercados menores, incluindo Darwin, Mildura, Griffith e Broken Hill, que atualmente não têm obrigações de transmissão de conteúdo local. Com a emenda na legislação, as emissoras deverão prover pelo menos 360 pontos (minutos) de conteúdo local.

Ademais, a reforma incentivará uma "filmagem local" da programação das emissoras, uma vez que a emissora adquirirá três pontos por cada minuto de conteúdo local que seja filmado na área local. O país acredita que a nova estrutura de pontos irá fortalecer a interação entre o conteúdo local e as comunidades locais.

Simplificamos abaixo as mudanças trazidas pela emenda à legislação australiana:

\begin{tabular}{|c|c|c|}
\hline \multicolumn{3}{|c|}{ Principais mudanças na legislação australiana } \\
\hline Regra & Como é hoje & Como ficará \\
\hline $\begin{array}{l}\text { Audiência ( } 75 \\
\text { per cent rule) }\end{array}$ & $\begin{array}{l}\text { Uma pessoa, por si só ou } \\
\text { como diretora de uma ou } \\
\text { mais companhias não terá } \\
\text { condições de exercer o } \\
\text { controle de uma emissora de } \\
\text { televisão comercial cuja } \\
\text { área de licenciamento tenha } \\
\text { uma população que exceda } \\
75 \% \text { da população da }\end{array}$ & $\begin{array}{l}\text { Não há mais limitação, mas } \\
\text { quando uma empresa ou } \\
\text { grupo econômico controlar } \\
\text { emissora cuja licença abranja } \\
\text { área com população igual ou } \\
\text { superior a } 75 \% \text { da população } \\
\text { australiana, deverá produzir } \\
\text { ao menos 900 pontos } \\
\text { (minutos) de conteúdo local a }\end{array}$ \\
\hline
\end{tabular}




\begin{tabular}{|c|c|c|}
\hline \multicolumn{3}{|c|}{ Principais mudanças na legislação australiana } \\
\hline Regra & Como é hoje & Como ficará \\
\hline & Austrália. & cada seis semanas. \\
\hline $\begin{array}{l}\text { Concentração } \\
\text { de mercado } \\
\text { (Two out of } \\
\text { three rule ) }\end{array}$ & $\begin{array}{l}\text { Uma pessoa ou grupo pode } \\
\text { apenas controlar } 2 \text { (duas) } \\
\text { das plataformas de mídia } \\
\text { (televisão comercial, rádio } \\
\text { comercial, jornais } \\
\text { associados) }\end{array}$ & $\begin{array}{l}\text { A regra será revogada e não } \\
\text { haverá tal limitação. }\end{array}$ \\
\hline $\begin{array}{l}\text { Concentração } \\
\text { de Mercado } \\
\text { (one to a } \\
\text { market rule) }\end{array}$ & $\begin{array}{l}\text { Uma pessoa, por si só ou } \\
\text { como diretora de uma ou } \\
\text { mais companhias não } \\
\text { poderá controlar mais de } \\
\text { uma emissora de televisão } \\
\text { na mesma área de } \\
\text { licenciamento. }\end{array}$ & A regra permanecerá idêntica. \\
\hline $\begin{array}{l}\text { Concentração } \\
\text { de Mercado }\end{array}$ & $\begin{array}{l}\text { Uma pessoa, por si só ou } \\
\text { como diretora de uma ou } \\
\text { mais companhias não } \\
\text { poderá controlar mais de } \\
\text { duas emissoras de rádio na } \\
\text { mesma área } \\
\text { licenciamento. }\end{array}$ & A regra permanecerá idêntica. \\
\hline $\begin{array}{l}\text { Pluralidade de } \\
\text { informação } \\
\text { (Five/four rule) }\end{array}$ & $\begin{array}{l}\text { São necessárias pelo menos } \\
5 \quad \text { (cinco) } \\
\text { independentes de mídia em } \\
\text { áreas } 4 \text { metropolitanas } \\
\text { (capitais dos estados) e } 4 \\
\text { (quatro) em regiões } \\
\text { menores. }\end{array}$ & A regra permanecerá idêntica. \\
\hline
\end{tabular}

Tabela 1: mudanças na legislação australiana.

\section{B) Alemanha}

O exemplo alemão é particularmente interessante, devido à sua ênfase na representação comunitária. Ao invés de focar na imparcialidade, o modelo alemão busca equilibrar os diferentes interesses da comunidade permitindo que diversos grupos (como igrejas, sindicatos, etc.) indiquem representantes para trabalhar no monitoramento das autoridades reguladoras 
regionais. Os membros das autoridades, desta forma, possuem interesses diferenciados e tal diversidade contribui para a imparcialidade das decisões e a independência da instituição como um todo. Ao contrário dos mecanismos reguladores que pretendem se isolar de qualquer viés, o modelo alemão internaliza as tendências de diferentes grupos sociais. O modelo buscou reconhecer o papel da mídia de promotor e garantidor da livre formação de opinião, através da criação em seu sistema legal de meios que promovessem a pluralidade de informações e perspectivas.

O debate acerca do tema no país conta com oito decisões históricas da Suprema Corte, as quais auxiliaram a moldar o sistema regulatório do setor e discutiram a legitimidade da restrição da liberdade de expressão das emissoras em face da garantia do direito fundamental dos telespectadores à liberdade de formação de suas próprias preferências e opiniões, desenvolvendo suas próprias conclusões a partir do universo de informações apresentadas.

A Alemanha, antes da década de 80, possuía um sistema de radiodifusão de monopólio de emissoras públicas e, apenas nesta década, por meio de uma decisão da Suprema Corte, foram introduzidos canais comerciais, momento em que o sistema passou a ser denominado um sistema dual de radiodifusão (marcado pela presença significativa de emissoras públicas e privadas). A Suprema Corte em si tem sido um importante ator no cenário regulatório alemão no que diz respeito ao setor da radiodifusão, tendo suas decisões funcionado muitas vezes como um parâmetro, estabelecendo princípios gerais que foram utilizados pelos estados alemães no exercício do poder legislativo em torno do tema. São 8 (oito) decisões da Suprema Corte alemã chamadas de "First TV Ruling", "Second TV ruling" e assim por diante. ${ }^{17}$

17 As decisões foram traduzidas pela Universidade do Texas e estão disponíveis em: www.law.utexas.edu/transnational/foreign-law-translations/german/case.php?id=641. 
Seguindo os parâmetros deixados pela Suprema Corte e tendo como base o art. $5^{\circ}$ (1) e (2) da Constituição Alemã ${ }^{18}$, os estados promulgaram o "Interstate Broadcasting Treaty" (Rundfunkstaatsvertrag) ${ }^{19}$, que funciona como uma lei federal, a qual deve ser observada pelos estados ao editarem suas leis estaduais acerca da radiodifusão. Dentre os principais pontos, pode-se citar:

(i) processo de licenciamento: há diferenças entre as legislações estaduais, mas a maioria dos estados estabelecem quotas de produções regionais, isto é, parte do conteúdo da programação deve ser produzida no respectivo estado. Emissoras estrangeiras não precisam de licença no caso de retransmissão via cabo, desde que o programa observe as regras da Convenção Europeia de Televisão Transfronteiras (1989). O “Interstate Broadcasting Treaty" dispõe que os canais devem apresentar significativas proporções de sua programação originárias de regiões de língua alemã e da Europa como um todo e, dispõe ainda que, com exceção de igrejas e universidades, a licença não será concedida a pessoas de direito público e partidos políticos;

(ii) pluralidade de opiniões: as emissoras comerciais devem assegurar pluralidade de opiniões e deve ser assegurada a oportunidade de grupos minoritários expressarem seus pontos de vista. Neste sentido, as emissoras são obrigadas a assegurar um tempo de sua programação à terceiras partes independentes que possam contribuir para a pluralidade da programação, em especial nas áreas de cultura, informação e educação. As emissoras devem reservar 260 minutos por semana de sua programação às terceiras partes, dentre os quais 75 minutos devem ser transmitidos entre 19 horas e $23 \mathrm{~h} 30$.

(iii) propaganda: transmissões de programas religiosos e programas infantis não podem ser interrompidas por propagandas. $\mathrm{O}$ tratado

\footnotetext{
${ }^{18}$ Estabelece o dispositivo: "Everyone shall have the right to freely express and disseminate ones opinion in form of speech, writing and pictures, and to freely inform oneself by using generally accessible sources. Freedom of press and freedom of reporting by means of broadcast and by using film are guaranteed. There shall be no censorship".

${ }^{19}$ A versão antiga está disponível em < http:/www.iuscomp.org/gla/statutes/RuStaV.htm > e a atual versão em alemão em <http://attorney.bei.t-online.de/060021.htm〉.
} 
estabelece que, de forma geral, o tempo dedicado à propaganda não pode ultrapassar $20 \%$ da transmissão diária da emissora e, além disso, estabelece tempos máximos específicos para determinados programas. Por fim, as propagandas não podem ser vinculadas a nenhuma programação de conteúdo editorial, de forma que devem ser anunciadas de forma distinta e separada da programação da emissora. Então, o início da propaganda deve ser indicado por meios visuais, geralmente incluindo a palavra "Werbung" (publicidade).

(iv) direito de resposta: é assegurado o direito de resposta à pessoa ou instituição que se sentiu ofendida com programação de determinada emissora. A resposta deve ser transmitida sem inserções, pelo mesmo tempo do programa que deu origem ao direito e está limitada aos seguintes fatores: (a) a parte afetada deve ter um interesse legítimo na resposta; (b) deve estar restrita a informações de fato e não deve conter acusações.

Além desses pontos, é importante salientar que a Alemanha dá uma atenção especial no que tange à proteção dos direitos das crianças. Neste sentido, há lei própria voltada para o setor, qual seja o "Protection of Young Persons Act", e o "Interstate Treaty on Protection of Minors in the Media" bem como autoridades reguladoras específicas. Há a Freiwillige Selbstkontrolle der Filmirtschaft (FSK), o órgão de auto-regulação que acompanha a classificação etária da programação das emissoras, bem como o horário dos programas a serem transmitidos e a Kommission Jugendmedienschutz (KJM), a autoridade reguladora estatal, cuja formação se deu por uma união de todas as autoridades reguladoras estatais, as quais entenderam necessária a presença de um órgão que analisasse especificamente questões envolvendo os direitos das crianças. Tanto o órgão regulador estatal quanto o de autorregulação devem cooperar e funcionar em harmonia. Na medida em que o FSK encontra um problema na programação de determinada emissora, o órgão encaminha a situação para a KJM analisar e decidir qual medida será tomada. Em contrapartida, quando a FSK autoriza o conteúdo de determinada programação por 
entendê-lo adequado, a KJM só poderá adotar posição contrária à referida decisão se demonstrar que a FSK agiu contrariamente à lei, isto é, que a transmissão do programa viola dispositivo legal.

\section{4 - Autoridades Reguladoras da Mídia}

No presente capítulo, pretendemos conceituar o termo autoridade reguladora da mídia, além de explicitar sua importância para o desenvolvimento de uma indústria de radiodifusão plural e democrática. Faremos ainda um panorama geral das autoridades reguladoras da mídia na Alemanha e na Austrália e, por fim, mostraremos as especificidades dessas autoridades em cada um desses países.

Em sentido amplo, autoridade reguladora (denominada no Brasil de agência reguladora) é qualquer órgão da Administração Pública Direta ou entidade da Administração Pública Indireta com função de regular a matéria específica que lhe está afeta ${ }^{20}$, sendo as autoridades reguladoras da mídia, portanto, responsáveis pela regulação da mídia.

De acordo com o "Guia para a regulação da Radiodifusão", publicado pela UNESCO em parceria com a Commonwealth Broadcasting Association - $C S A^{21}$, a prática mais democrática e aceita ao redor do mundo para o desenvolvimento de uma indústria de radiodifusão independente é a criação de um sistema regulador também independente com a finalidade de licenciar e fiscalizar tal indústria.

Como já mencionamos, o desenvolvimento da democracia requer a disponibilidade de uma variedade de fontes de informação e de opinião para que a população possa tomar decisões informadas e para que possam formar livremente suas opiniões individuais. Hoje ainda, em todo mundo, televisão e rádio representam uma das principais fontes de notícias e informações e,

\footnotetext{
${ }^{20}$ DI PIETRO, Maria Sylvia. Direito Administrativo.15.ed. São Paulo: Atlas, 2003, p. 402.

${ }^{21}$ SALOMON, Eve. Guidelines for Broadcasting Regulation. 2. ed. Londres: Commonwealth Broadcasting Association, 2008.
} 
para fomentar o debate, é necessário que haja uma pluralidade de prestadores de serviços que permitam aos ouvintes uma ampla gama de fontes de notícias e informações.

Ora, se o governo é responsável pela determinação das licenças desses prestadores de serviços, bem como pela fiscalização, esses integrantes da indústria tendem abertamente a apoiar o governo, o que poderia em certo grau comprometer a livre formação de opinião da população. É nesse sentido que se torna fundamental a presença de um sistema regulador independente, tanto de setores econômicos, quanto políticos, para deixar o setor mais democrático e plural.

Ao iniciarmos a investigação do tema do presente trabalho, identificamos autoridades reguladoras da mídia em 49 países, distribuídas de forma dispersa ao redor do mundo, sendo Austrália e Alemanha federações que integram a referida lista, isto é, ambos os países possuem suas autoridades reguladoras da mídia.

Para entendermos, então, o sistema regulatório dos dois países, é fundamental que compreendamos o funcionamento de suas agências reguladoras, suas estruturas organizacionais e financeiras, suas competências e o processo decisório de cada uma delas, eis que tais peculiaridades influenciam diretamente no modo como esses países lidam com a regulação de conteúdo no setor da radiodifusão.

Inicialmente, antes de falarmos especificamente de cada autoridade reguladora, importante mencionar que há determinadas características consideradas fundamentais para a garantia de um sistema regulatório independente.

Dentre tais características $^{22}$, podemos citar: (i) nomeação dos membros: é vital que os meios de nomeação sejam claramente estipulados em lei e sejam realizados de forma democrática e transparente, para que a

\footnotetext{
${ }^{22}$ SALOMON, Eve. Guidelines for Broadcasting Regulation. 2. ed. Londres: Commonwealth Broadcasting Association, 2008.
} 
autoridade reguladora seja capaz de funcionar livre de qualquer interferência ou pressão de forças políticas ou econômicas; (ii) competência: as atribuições e competências da autoridade independente devem ser estabelecidas em lei, bem como os meios através dos quais elas serão responsabilizadas; (iii) financiamento: pode ser utilizado como um meio de pressão política (se a autoridade não agir de acordo com os desejos do governo o financiamento pode ser retirado). Os termos de financiamento, portanto, devem ser definidos em lei, e sempre que possível mantidos separados de qualquer potencial interferência política; e (iv) conflito de interesses: os membros da autoridade reguladora devem estar livres de qualquer conflito de interesse pessoal com o setor de radiodifusão. É comum que seja proibido que os membros ou suas famílias tenham interesses financeiros na indústria da radiodifusão ou empresas associadas.

Em linhas gerais, a estrutura do sistema de regulação de radiodifusão na Alemanha é composta por 1 (uma) autoridade reguladora federal (die Medienanstalten) e 14 (catorze) autoridades reguladoras estaduais ${ }^{23}$, com órgãos internos compostos por representantes de grupos sociais e pessoas com expertise no tema (as agências em si lembram o sistema de agências reguladoras no Brasil). As autoridades são responsáveis pela concessão das licenças, supervisão de todos os campos de regulação (proteção dos menores, propaganda, conteúdo da programação) e podem utilizar diferentes instrumentos e sanções, começando pela declaração formal de que houve violação das condições de licenciamento por parte de determinada emissora, até a aplicação de multas ou revogação da licença.

Já o sistema regulatório australiano compreende apenas uma autoridade reguladora, qual seja, Australian Communications and Media Authority ("ACMA"), criada pelo Australian Communications and Media

\footnotetext{
${ }^{23}$ Embora a federação alemã tenha 16 estados, duas agências estaduais abrangem 2 estados cada uma, de modo que as 14 agências cobrem todos os 16 estados-membros da federação.
} 
Authority $A c t^{24}$, a qual funciona como uma agência reguladora federal, independente, sendo parte integrante do portfólio das artes e comunicações.

É responsável pela regulação do sistema de radiodifusão e da internet, sendo o órgão competente para o licenciamento das emissoras, para a regulação de conteúdo da programação e para fiscalizar se as condições de licença das emissoras estão sendo cumpridas e se as transmissões estão de acordo com a legislação pertinente.

\section{2 - Estrutura Organizacional}

\section{A) Austrália}

As atividades do dia-a-dia da ACMA são geridas por uma equipe executiva que inclui o Presidente, o Vice-Presidente (membros de tempo integral), um terceiro membro em tempo integral, quatro gerentes gerais (em tempo parcial) e 11 gerentes executivos. Os gerentes gerais são responsáveis por quatro grandes áreas, quais sejam:

(i) Infraestrutura das Comunicações: responsável pela regulação técnica (controle da qualidade da transmissão); campo operacional, compliance e licenciamento.

(ii) Conteúdo, Consumidor e Cidadão: responsável pela condução das investigações, regulação de conteúdo, diversidade, quotas regionais e acessibilidade (esse último está relacionado a regulação de conteúdo cibernético, também de responsabilidade dessa autoridade reguladora).

(iii) Corporativo e Pesquisa: responsável pelas finanças, orçamento, receitas, programa de governança, pesquisa e análise e elaboração das normas pertinentes.

(iv) Serviços legais: assessoria jurídica da autoridade reguladora.

\footnotetext{
${ }^{24}$ Disponível em: https://www.legislation.gov.au/Details/C2005A00044>Acesso em 03.10.16.
} 
De acordo com o art. 20 do Australian Communications and Media Authority Act, cada membro deve ser nomeado pelo Governador Geral por meio de instrumento escrito. Importante ressaltar que membros de meio período (tempo parcial) podem ser nomeados pelo Ministro, desde que aprovada a nomeação pelo conselho da ACMA, devendo tal nomeação ser feita por escrito.

Ainda conforme a norma criadora da ACMA, o período do mandato será definido no termo de nomeação, por escrito, o qual não poderá ser superior a 5 (cinco) anos. Aliás, os membros podem ainda ser nomeados para cumprir novos mandatos, mas a soma dos períodos não poderá ser superior a $10(\mathrm{dez}) \operatorname{anos}^{25}$.

As áreas são ainda divididas em ramos e seções com funções específicas. Informações mais detalhadas estão disponíveis no gráfico abaixo:

\footnotetext{
25 "21 Section: (1) A member holds office for the period specified in his or her instrument of appointment. The period must not exceed 5 years. (2) A person can be appointed as a member more than once. However, a later appointment must not result in the sum of the person's periods of appointment exceeding 10 years". Disponível em: https://www.legislation.gov.au/Details/C2005A00044>Acesso em 30.10.16.
} 


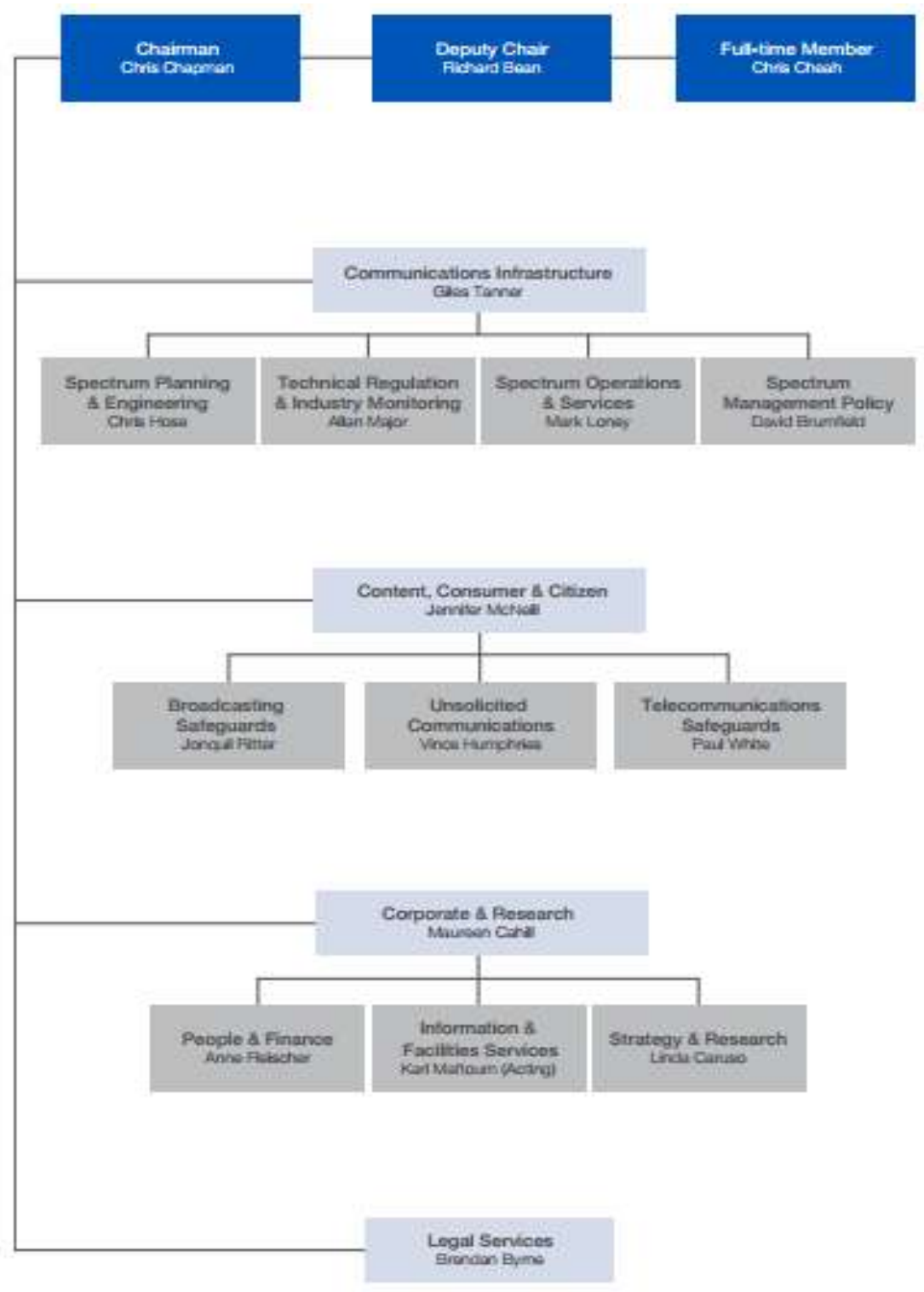

Imagem 1: estrutura organizacional da ACMA.

\section{B) Alemanha}

Como mencionado, a estrutura do sistema de regulação de radiodifusão na Alemanha compreende 1 (uma) autoridade reguladora federal (die Medienanstalten) e 14 (catorze) autoridades reguladoras estaduais. As autoridades reguladoras estaduais têm diferentes estruturas organizacionais, mas suas normas internas devem obedecer às diretrizes gerais estabelecidas pela autoridade reguladora federal. Ater-nos-emos aqui a demonstrar a estrutura organizacional da autoridade federal. 
A Medienanstalten é composta por três comissões especiais, a Comissão de Proteção de Crianças e Adolescentes, responsável pela regulação no âmbito da proteção aos menores (Kommission fuer Jugendmedienschutz - KJM), a Comissão para Licenciamento e supervisão, responsável por conceder as licenças e fiscalizar a indústria (Kommission fuer Zulassung und Aufsicht - ZAK) e a Comissão para Concentração da Mídia, responsável pela fiscalização e controle das operações de fusão, incorporação ou quaisquer outras que afetem a concentração da indústria midiática ("Kommission zur Ermittlung der Konzentration im Medienbereich - KEK").

Além dessas comissões destinadas a assuntos específicos, a autoridade reguladora é composta por um colegiado de diretores, um conselho de tomada de decisões e um conselho técnico responsável por questões técnicas e qualidade da transmissão.

Informações mais detalhadas estão disponíveis na imagem abaixo:

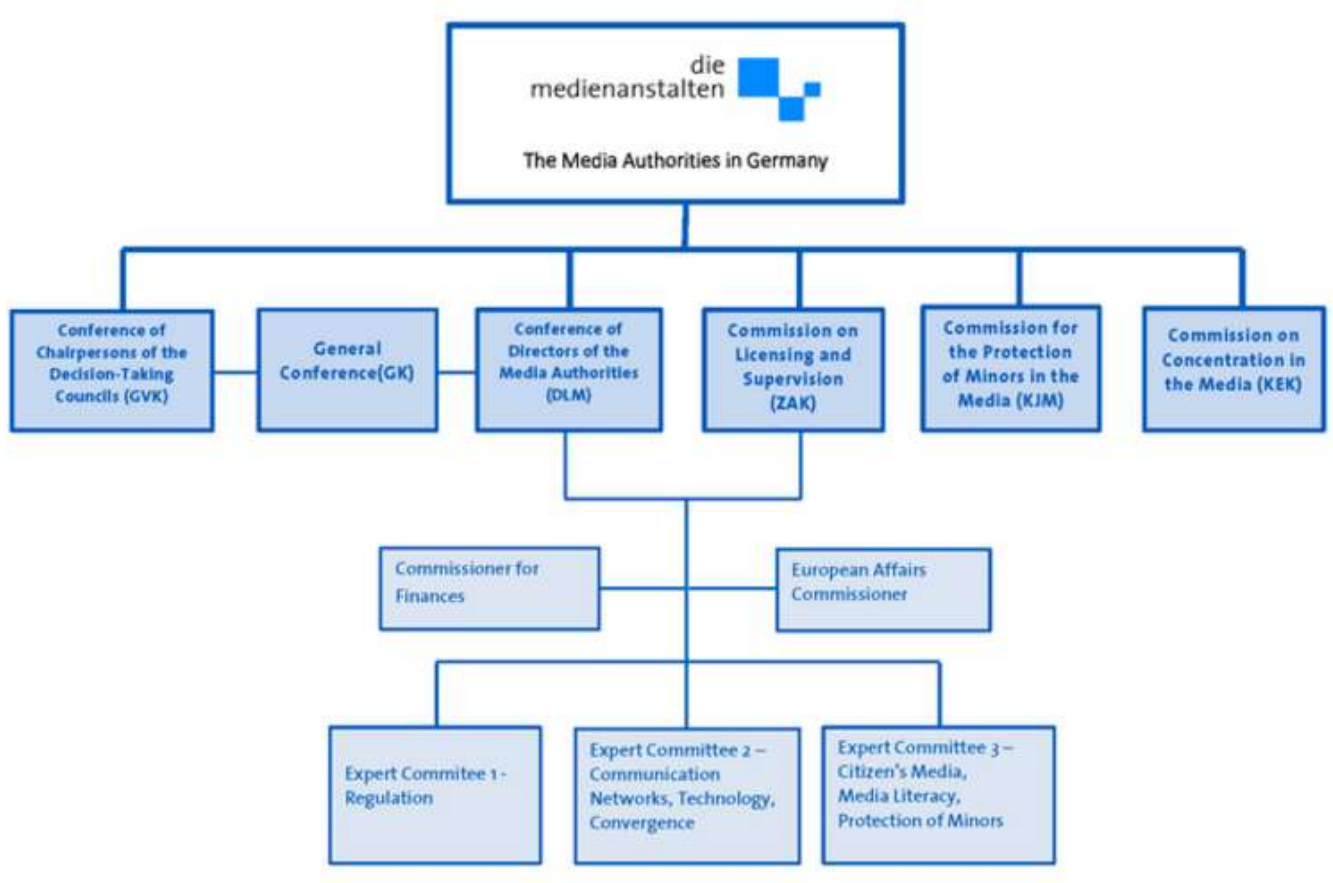




\section{2 - Estruturação Financeira}

\section{A) Austrália}

A ACMA tem competência para recolher os impostos, encargos e taxas de licença estipulados em lei para o setor da radiodifusão. Tais taxas de serviço, entretanto, apesar de propiciarem certa independência financeira à autoridade reguladora, não são suficientes para a sua manutenção.

$\mathrm{Na}$ realidade, a maior parte da receita da ACMA vem de repasses do governo federal australiano, o que pode ser considerado perigoso para a independência financeira da agência.

\section{B) Alemanha}

A Alemanha possui uma taxa de contribuição mensal obrigatória para todos os moradores do país, independentemente de possuírem equipamentos de rádio e televisão. Cada casa é responsável pelo pagamento da contribuição, que em 2013 custava cerca de 18 euros por mês, e, tal contribuição é responsável por financiar as agências reguladoras, bem como as emissoras públicas de radiodifusão. Há possibilidade de requerimento para redução do valor da contribuição para pessoas beneficiárias de auxílio desemprego e àquelas portadoras de necessidades especiais, casos em que a contribuição chega a ser reduzida em 60\%. Ademais, é possível que residências que não possuam aparelhos de televisão e somente de rádio façam o requerimento da chamada "reduced radio-only fee".

Além disso, empresas e instituições também devem pagar uma taxa de contribuição (calculada conforme número de empregados, veículos, e outros fatores dependendo do setor da empresa). Importante mencionar que apesar da contribuição ser em regra mensal, há possibilidades de pagamento trimestral. 
É interessante que a Alemanha possui atualmente um dos maiores orçamentos do mundo para o financiamento de suas emissoras públicas, e a renda anual obtida através das referidas taxas de contribuição é de aproximadamente 7,6 bilhões de euros.

\section{3 - Competências}

\section{A) Austrália}

As competências da ACMA estão especificadas de forma bastante geral no art. $8^{\circ}$ do Australian Communications and Media Authority Act ${ }^{26} \mathrm{e}$ são elas: (i) regular as telecomunicações, concedendo o licenciamento às emissoras mediante o cumprimento de determinados requisitos; (ii) aconselhar e ajudar a indústria de telecomunicações; (iii) informar e aconselhar o ministro em relação à indústria de telecomunicações; (iv) informar e aconselhar o ministro em relação a questões afetando telespectadores; (v) garantir o estabelecimento de padrões internacionais de telecomunicações; (vi) monitorar todas as questões significativas relativas ao licenciamento das emissoras; (vii) disponibilizar ao público informações sobre assuntos relativos ao setor de telecomunicações; (viii) conduzir programas educacionais públicos sobre assuntos relativos ao setor de telecomunicações;

Qualquer indivíduo ou organização pode fazer uma denúncia à ACMA sobre a conformidade de uma emissora australiana com um código de prática, condição de licença ou standard. Dependendo da norma em relação a qual é feita a denúncia, serão diferentes as exigências para a reclamação e as medidas as quais a autoridade reguladora poderá tomar após eventual decisão de descumprimento. Elaboramos a tabela abaixo para facilitar o entendimento acerca do assunto.

\footnotetext{
${ }^{26}$ Disponível em: https://www.legislation.gov.au/Details/C2005A00044>Acesso em 30.10.16.
} 


\begin{tabular}{|c|c|c|}
\hline Norma & Requisitos da denúncia & $\begin{array}{l}\text { Possíveis medidas após decisão de } \\
\text { violação }\end{array}$ \\
\hline \multirow{3}{*}{$\begin{array}{l}\text { Código de } \\
\text { Prática }\end{array}$} & \multirow{3}{*}{$\begin{array}{l}\text { Deve primeiro ser feita } \\
\text { reclamação por escrito à } \\
\text { emissora de radiodifusão. } \\
\text { Se não recebe uma resposta } \\
\text { no prazo de } 60 \text { dias ou não } \\
\text { estiver satisfeito com a } \\
\text { resposta recebida, } \\
\text { apresenta uma queixa junto } \\
\text { a ACMA, fornecendo } \\
\text { cópia da denúncia original } \\
\text { encaminhada à emissora e } \\
\text { cópia da resposta, caso } \\
\text { tenha sido recebida. }\end{array}$} & $\begin{array}{l}\text { ACMA concorda em aceitar } \\
\text { medidas propostas pelas próprias } \\
\text { emissoras, para melhorar a } \\
\text { conformidade com as normas. }\end{array}$ \\
\hline & & $\begin{array}{l}\text { ACMA aceita um compromisso } \\
\text { exequível proposto pela própria } \\
\text { emissora com o fim de garantir o } \\
\text { futuro cumprimento da regra. }\end{array}$ \\
\hline & & $\begin{array}{l}\text { ACMA impõe uma condição de } \\
\text { licença adicional, exigindo o } \\
\text { licenciado a cumpri-la. (não } \\
\text { aplicável às emissoras púbicas). }\end{array}$ \\
\hline \multirow{7}{*}{ Standard } & \multirow{7}{*}{$\begin{array}{l}\text { A denúncia pode ser feita } \\
\text { diretamente à ACMA. }\end{array}$} & $\begin{array}{l}\text { Concorda em aceitar medidas } \\
\text { propostas pela emissora. }\end{array}$ \\
\hline & & $\begin{array}{l}\text { Aceita um compromisso exequível } \\
\text { proposto pela própria emissora com } \\
\text { o fim de garantir o futuro } \\
\text { cumprimento da regra. }\end{array}$ \\
\hline & & $\begin{array}{l}\text { Suspende a licença por um período } \\
\text { determinado. }\end{array}$ \\
\hline & & Cancela a licença. \\
\hline & & $\begin{array}{l}\text { Prossegue com uma penalidade civil } \\
\text { na Justiça Federal. }\end{array}$ \\
\hline & & $\begin{array}{l}\text { Remete a questão ao Diretor do } \\
\text { Ministério Público. }\end{array}$ \\
\hline & & $\begin{array}{l}\text { Altera ou revoga uma condição de } \\
\text { licença, ou impõe uma condição de } \\
\text { licença adicional. }\end{array}$ \\
\hline $\begin{array}{l}\text { Condição } \\
\text { de Licença }\end{array}$ & $\begin{array}{l}\text { A denúncia pode ser feita } \\
\text { diretamente à ACMA. }\end{array}$ & $\begin{array}{l}\text { Mesmas medidas de violação à } \\
\text { Standard. }\end{array}$ \\
\hline \multirow{4}{*}{$\begin{array}{l}\text { Condição } \\
\text { de Licença } \\
\text { Adicional }\end{array}$} & \multirow{4}{*}{$\begin{array}{l}\text { A denúncia pode ser feita } \\
\text { diretamente à ACMA. }\end{array}$} & $\begin{array}{l}\text { Concorda em aceitar medidas } \\
\text { propostas pela emissora. }\end{array}$ \\
\hline & & $\begin{array}{l}\text { Aceita um compromisso exequível } \\
\text { proposto pela própria emissora com } \\
\text { o fim de garantir o futuro } \\
\text { cumprimento da regra. }\end{array}$ \\
\hline & & $\begin{array}{l}\text { Suspende a licença por um período } \\
\text { determinado. }\end{array}$ \\
\hline & & Cancela a licença. \\
\hline
\end{tabular}

Tabela 2: Regras sobre denúncias à ACMA 
Os diferentes requisitos das denúncias, bem como as diferentes possíveis medidas tomadas pela ACMA em caso de violação das regras do sistema de radiodifusão, demonstram a característica da co-regulação. A própria criação dos Códigos de Prática, elaborados pelos setores da indústria, enfatizam a forma de regulamentação adotada pelo país.

É importante mencionar que a ACMA pode decidir investigar um assunto de ofício e estas investigações podem ser iniciadas a qualquer momento. O elemento-chave para a ACMA exercer o seu poder de investigar qualquer assunto é o interesse público. Se a autoridade entender que ele está presente, iniciará seus trabalhos investigativos acerca do tema, sendo certo que tem discricionariedade nessa decisão. Inclusive, os casos que encontramos questionando judicialmente a decisão da autoridade em iniciar determinada investigação foram julgados improcedentes, havendo hoje uma decisão da Suprema Corte australiana acerca da discricionariedade da ACMA quanto à decisão sobre iniciar ou não uma investigação.

Ao receber uma reclamação válida, a ACMA considera o(s) assunto(s) levantado(s) na denúncia e, em seguida, informa o denunciante se a questão será investigada. Caso decida investigar, informará a emissora da denúncia e da investigação, requerendo comentários da emissora e podendo requerer a cópia da transmissão a ser analisada. Na decisão da autoridade sobre a programação, será levada em consideração a legislação pertinente (incluindo códigos de prática e standards), as orientações da ACMA (é comum vermos nas decisões citações de precedentes já decididos pela autoridade reguladora) e orientações jurisprudenciais sobre a questão (caso haja revisão judicial).

\section{B) Alemanha}

Na Alemanha, as autoridades reguladoras estaduais são responsáveis pela concessão de licença às emissoras de radiodifusão estaduais, enquanto 
a autoridade reguladora federal tem competência para o licenciamento de emissoras de caráter nacional. Às autoridades reguladoras estatais é garantida uma série de instrumentos sancionadores para o caso de violação, por parte das emissoras, das normas aplicáveis.

Em primeiro lugar, a autoridade emite uma notificação formal declarando que houve uma violação de determinada norma ou condição de licença e impõe uma obrigação de fazer ou não fazer para a emissora, com a finalidade de prevenir violações futuras.

Se novamente violações são cometidas pela emissora no mesmo sentido da notificação formal, há outros remédios pelos quais pode se valer a autoridade reguladora, que vão desde a imposição de multas até a revogação da licença.

Todavia, importante mencionar que o sistema regulatório alemão enfrenta alguns problemas relacionados à aplicação efetiva da regra. Para contornar tal situação, as autoridades reguladoras da mídia estaduais têm estabelecido alguns instrumentos informais de regulação, através de uma cooperação com as próprias emissoras de radiodifusão, promovendo uma sensibilização dos telespectadores, estimulando-os a adotar uma postura mais participativa, bem como encorajando-os a denunciar situações que entendam ser contrárias as normas vigentes.

As comissões da autoridade reguladora envolvidas com a proteção de menores têm ainda competência para retirar determinados programas do ar ou bloquear conteúdos, se ficar decidido, após investigação, que a emissora violou regras referentes à proteção de crianças e adolescentes. Tais comissões também possuem competência para aplicar multa às emissoras, sendo certo que, nesse âmbito, deve ser preservada a primazia da autorregulação que, como já mencionado, é promovida pela Freiwillige Selbstkontrolle der Filmirtschaft (FSK). 


\section{5 - Estudo de Casos}

\section{1 - Panorama geral dos casos}

Em relação à Austrália, identificamos 129 casos envolvendo regulação conteudística da programação das emissoras comerciais que operam no sistema de radiodifusão australiano, no período de 2013 a 2015. Todos os casos estão publicados na plataforma online da ACMA. ${ }^{27}$ Dentre os casos listados, apenas 12,4\% apresentaram decisão desfavorável para as emissoras e consideraram que houve violação à lei. Cabe salientar que a maioria das decisões que entenderam ter havido violação são referentes à qualidade de captação das imagens, não envolvendo o conteúdo em si da programação.

Além disso, notamos outros temas frequentes nas decisões envolvendo regulação de conteúdo, quais sejam, veracidade das alegações, imparcialidade/diversidade de perspectivas, programas inapropriados para classificação e discurso ofensivo ou discriminatório. As referidas informações podem ser visualizadas nos gráficos abaixo.
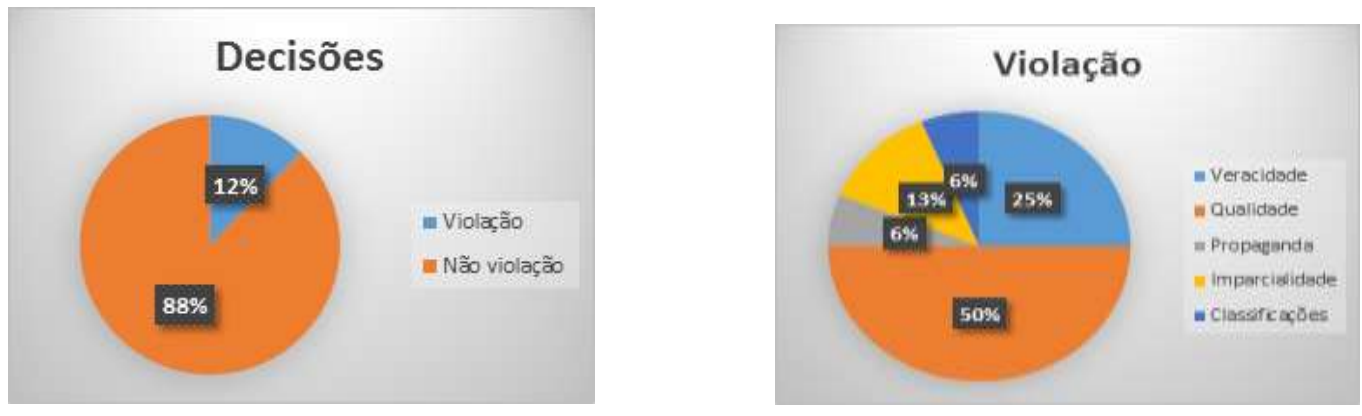

No Anexo I ao presente trabalho, listamos todos os casos, retirados os que envolviam má qualidade da transmissão. Optamos por expor a seguir, mais detalhadamente, cinco casos: quatro envolvendo a violação do art. $1.9 .6^{28}$ do Código de Prática das Emissoras de Televisão Comerciais e um relacionado a questão de imparcialidade no âmbito de noticiários.

\footnotetext{
27 Disponível em: http://www.acma.gov.au/theACMA/ACMAi/Investigation-reports < Acesso em 20/07/2016

28 “1.9. A licensee may not broadcast a program, program promotion, station identification or community service announcement which is likely, in all the circumstances, to: [...] 1.9.6 provoke or perpetuate
} 
No que tange à Alemanha, listamos os casos a partir da base de dados disponível no Merlin observatory ${ }^{29}$, que listou 20 casos envolvendo a regulação de conteúdo do sistema de radiodifusão na Alemanha no âmbito das emissoras comerciais entre os anos de 2000 a 2014, e foram analisados a partir do teor disponível nos endereços eletrônicos da autoridade reguladora federal alemã (die Medienanstalten), das autoridades reguladoras estaduais de radiodifusão e do Tribunal Constitucional Alemão (Bundesverfassungsgericht) .

Dos 20 casos listados, 4 não passaram pela esfera administrativa e foram levados diretamente ao Poder Judiciário. Os outros 16 casos foram decididos pela autoridade e, em seguida, pelo tribunal administrativo, sendo que 3 desses casos foram levados depois ao Poder Judiciário. Dos 13 (treze) casos que ficaram apenas na esfera administrativa (autoridade reguladora e tribunal administrativo), a decisão da autoridade reguladora foi reformada pelo tribunal administrativo em apenas 1 (um) caso. Nos 3 (três) casos que foram levados também ao Poder Judiciário, este manteve a decisão da autoridade reguladora confirmada pelo tribunal administrativo.

Um destes três casos foi levado também à Corte Europeia de Direitos Humanos, que também manteve a decisão administrativa. Este quadro, embora resulte da análise de um universo limitado, sugere algum prestígio dos órgãos reguladores na Alemanha - o que corrobora a premissa citada na introdução e assumida neste trabalho de que, longe de ser uma medida autoritária, algum grau de regulação é fundamental numa sociedade democrática.

\footnotetext{
intense dislike, serious contempt or severe ridicule against a person or group of persons on the grounds of age, colour, gender, national or ethnic origin, disability, race, religion or sexual preference;" 29 A pesquisa concentrou-se no banco de dados IRIS Merlin, disponível em http://merlin.obs.coe.int/, que é parte do departamento de informações jurídicas do Merlin Observatory, criado pelo estatuto do Observatório Europeu Audiovisual, organização pública integrante do Conselho Europeu e composta por 37 estados-membros e pela União Europeia, o qual surgiu com o intuito de desenvolver e transferir informações da indústria audiovisual europeia e promover uma visão clara e transparente deste mercado. O banco de dados conta com a parceria do Institute of European Media Law, Institute for Information Law, Moscow Media Law and Policy Center (MMLPC) e o The Media Center at New York Law School.
} 
Em relação aos temas discutidos, a maior parte envolveu a proteção do direito das crianças (30\% dos casos), a proteção da dignidade humana (15\% dos casos) e anúncios publicitários, mais especificamente a associação de propaganda com a programação da emissora, o que é vedado pela legislação alemã (15\% dos casos). Os outros $40 \%$ relacionam-se a temas variados.

Para o presente trabalho, foram analisados mais detalhadamente 4 casos, os quais serão expostos a seguir.

\section{2 - Apresentação dos casos}

\section{A) Austrália}

O primeiro caso a ser destacado (Channel Seven vs. ACMA) refere-se ao programa Sunday Tonight, o qual transmitiu documentário de 20 minutos acerca da tribo indígena Suruwaha, que vive na floresta amazônica, no Brasil. O programa classificou a tribo brasileira dos Suruwaha como assassinos de crianças; relíquias da 'Idade da Pedra'; e 'alguns dos piores violadores dos direitos humanos no mundo'.

No documentário, integrantes da tribo foram filmados caçando, conduzindo rituais e vivendo sua rotina usual e, além disso, o segmento continha entrevistas com dois homens integrantes da tribo e um advogado de direitos humanos.

$\mathrm{O}$ apresentador do programa afirmou que "aqui estamos fora da proteção da lei brasileira", "essa tribo isolada incentiva o assassinato de crianças com deficiência física", "os Suruwaha acreditam que crianças nascidas com deficiências ou de mães solteiras possuem espíritos malignos e devem ser mortos da forma mais macabra possível. Eles levam os pobres bebês inocentes para a selva para serem comidos vivos pelas feras selvagens ou onças ou eles os enterram vivos. Essa é uma das mais terríveis violações de direitos humanos no mundo".

Após a transmissão ir ao ar, a ACMA recebeu uma reclamação sobre o documentário. O reclamante alegou que a emissora fez declarações 
inexatas e que o documentário era suscetível provocar intensa aversão, desprezo grave, bem como ridicularizava a tribo Suruwaha, em razão de sua origem étnica e racial, violando, portanto, o art. 1.9.6 do Código de Prática das Emissoras de Televisão Comerciais ${ }^{30}$.

A reclamação baseou-se em duas premissas: (i) as declarações de inaplicabilidade da lei brasileira no local em que vive a tribo foram imprecisas e não apuradas; e (ii) foram também imprecisas e inverídicas as afirmações acerca da prática constante de infanticídio por parte da tribo.

A ACMA considerou que houve violação do art. 19.6 do Código de Prática das Emissoras de Televisão Comerciais sob os seguintes argumentos: (a) a linguagem utilizada pelo repórter foi assertiva e não continha nenhuma referência à prática ser ocasional e esporádica; (b) o uso das palavras "acreditam que as crianças devam ser mortas" e "incentivar o assassinato de crianças deficientes", todas enquadradas no tempo presente indicam que atualmente existem as crenças e as ações da tribo, sem exceção; (c) o espectador comum, razoável, teria entendido, a partir das declarações, que o infanticídio é um fato incontestável, indiscutível e que os Suruwaha atualmente acreditam que as crianças nascidas com deficiências ou de mãe solteira são más e devem ser mortos.

Vale citar trechos da decisão da ACMA, quais sejam: "que as passagens acima acerca do infanticídio foram suscetíveis de provocar intensa aversão e desprezo grave em relação à tribo e a prática foi identificada como um atributo central dos membros da tribo"; "o programa associou a prática do infanticídio com a tribo Suruwaha como um todo, e o conteúdo do programa sugeriu que o infanticídio era praticado sem remorso e em circunstâncias horríveis, descrevendo as ações da tribo em linguagem altamente emotiva. $O$ documentário certamente sugere a conexão da prática do infanticídio com a etnia da tribo Suruwaha".

\footnotetext{
${ }^{30}$ 1.9. A licensee may not broadcast a program, program promotion, station identification or community service announcement which is likely, in all the circumstances, to: [...] 1.9.6 provoke or perpetuate intense dislike, serious contempt or severe ridicule against a person or group of persons on the grounds of age, colour, gender, national or ethnic origin, disability, race, religion or sexual preference;"
} 
O canal Seven pleiteou revisão judicial das constatações de violação publicadas pela ACMA e o caso chegou à corte federal da Austrália, a qual, por unanimidade, negou provimento ao pedido da emissora, sob o argumento de que a ACMA era competente para decidir sobre as violações dos Códigos de Prática, não tendo sido infringida qualquer lei.

Interessante observar que é raro, na Austrália, que sejam conhecidas as revisões judiciais por parte do Tribunal. A esfera administrativa, por ser marcada pela presença de setores da indústria e da sociedade civil, é bastante privilegiada, e revisões judiciais só são aceitas se ficar comprovado que houve violação à lei no processo de investigação por parte da ACMA.

Ou seja, a esfera judicial não analisa se houve violações dos Códigos de Prática ou interfere em questões que envolvem regulação de conteúdo, pois tal matéria é considerada de competência exclusiva da esfera administrativa. É preciso que tenha havido ilegalidades no processo investigatório para que seja conhecida a revisão judicial.

Portanto, esse caso, como muitos outros que observamos, teve negado seguimento na esfera judiciária. Vale ainda enfatizar que notamos que são poucos os requerimentos de revisão judicial por parte das emissoras, as quais normalmente concordam com as decisões da ACMA.

Em relação ao referido caso, a emissora de TV fazia questão de ser considerada inocente, principalmente porque o processo teve uma repercussão muito negativa para os telespectadores e porque a emissora chegou a ser acusada pela ONG Survival Internacional de ter vínculos com missionários evangélicos que atuavam de forma radicalmente contrária às práticas culturais da tribo indígena brasileira. A organização evangélica teria recebido altas doações da emissora de televisão, além de ter proposto, junto à bancada evangélica do Congresso Nacional Brasileiro, projeto de lei permitindo a retirada de crianças indígenas de suas famílias, sob o argumento de que a tribo é extremamente "primitiva". 
O segundo caso (TCN Channel Nine's - All Asian mall) refere-se ao programa Current Affair, o qual transmitiu uma história intitulada All-Asian Mall sobre as mudanças em um centro comercial no subúrbio de Sidney.

A ACMA entendeu que segmentos da história All-Asian Mall foram transmitidos de forma imprecisa, tais como: (i) foi informado que lojas de asiáticos ocupariam "quase todas" as lojas do primeiro andar do shopping. (Na verdade, o plano era que quatro dos 16 varejistas fossem lojas especializadas em produtos asiáticos); (ii) foi informado que os lojistas australianos "Aussie" tinham sido forçados a se mudar para abrir caminho para novos varejistas, visando atingir a população asiática do subúrbio. ( $\mathrm{Na}$ verdade, os novos varejistas estavam sendo introduzidos porque outras lojas já haviam fechado); (iii) O programa contou que o plano de gestão do shopping era forçar outros varejistas a desocupar o shopping inteiramente. (Na verdade, o plano era mudar a localização das lojas dentro do shopping); (iv) O programa mostrou um açougueiro afirmando que "teve que se mudar". (Na verdade, o açougueiro não foi afetado pelo plano).

A ACMA também entendeu que a história retratava pessoas de etnia asiática de forma negativa, em contraste com a nacionalidade australiana, bem como poderia provocar intensa aversão ou desprezo, uma vez que transmitia (a) informação negativa sobre os australianos de origens étnicas asiáticas; (b) linguagem capaz de gerar sentimento de ameaça quanto às pessoas de origens étnicas asiáticas; e (c) linguagem que aduz que os australianos de origens étnicas asiáticas não pertenceriam à Austrália.

A ACMA entendeu não haver violação do art. 4.3.2 do Código de Prática (provocar pânico público), mas decidiu pela violação do art. 4.3.1. (matéria de fato transmitida de forma imprecisa), do art. 4.3.10 (provocou ênfase negativa em pessoas de determinada origem étnica) e do art. 1.9.6 (era susceptível de provocar intensa aversão e desprezo grave em razão da origem étnica). 
A ACMA recomendou a emissora que fizesse uma declaração sobre o programa, corrigindo o que foi dito e que fosse removido o programa do site da emissora. A emissora concordou com ambas as recomendações.

É interessante observar que aqui, diferentemente do caso exposto anteriormente, a emissora concordou com as recomendações da autoridade reguladora de imediato, sem a interposição de quaisquer recursos administrativos ou requerimentos de revisões judiciais, o que sugere algum consenso quanto aos limites impostos pela ACMA.

O terceiro caso que analisamos (Family Guy - "Distasteful and offensive treatment of the Christian God") refere-se a um episódio do programa Family Guy, intitulado Seinfeld, o qual foi transmitido pelo Channel Seven. O programa apresentou diálogo entre Maria e José, conforme abaixo:

"Male character: So you're saying God got you pregnant?

Female character: Yes Joseph, glory in the highest.

Male character: Well if it is his will, then his will be done, and I am but his humble servant. But I do have one question - was he bigger than me?

Female character: Joseph it wasn't like that - I felt nothing.

Male character: Oh. Little guy."

Alguns telespectadores apresentaram reclamações na ACMA por terem classificado o episódio como ofensivo e entenderam que a transmissão teria zombado do Deus cristão de forma vulgar. Os reclamantes entenderam ainda ser o programa desrespeitoso e alegaram que houve violação do art. 1.9.6 do Código de Prática das Emissoras de Televisão Comerciais $^{31}$. A ACMA decidiu pela não violação do referido dispositivo sob os seguintes argumentos: (i) a lei define um limite alto para o efeito de conteúdo proibido. Os termos "intensa aversão", "sério desprezo" e "ridicularizar gravemente" indicam que o Código contempla situações em que há uma reação negativa muito forte dos telespectadores para com a transmissão; (ii) programas como o Family Guy podem conter humor de caráter irreverente; (iii) O tom da programação foi irreverente e bemhumorado, de acordo com o formato geral do programa Family Guy; (iv) Os personagens animados não foram retratados nas atividades explícitas, o

\footnotetext{
${ }^{31}$ Idem.
} 
humor verbal foi alcançado através de insinuações e a programação não continha descrições sexuais explícitas ou linguagem indecente; (v) Não houve palavras, imagens ou mensagens expressas que teriam sido entendidas pelo espectador comum razoável como provocativos e/ou que pudessem perpetuar reações intensas contra pessoas em razão da sua fé cristã; e (vi) o conteúdo da promoção não era tão forte, severo ou extremo que pudesse provocar ou perpetuar intensa aversão, desprezo ou que ridicularizasse gravemente uma pessoa ou grupo cristão em razão da sua religião.

Aqui é possível perceber a diferença de tratamento entre um programa de caráter jornalístico e um programa de comédia. Quando a ACMA decidiu no caso da tribo indígena Suruwaha, que envolvia discussões sob o mesmo dispositivo do Código de Prática, foi levado em consideração o caráter do programa, de cunho jornalístico, que transmitiu documentário com imprecisões fáticas e capazes de gerar aversão do público à tribo, já que as informações foram transmitidas de forma inverídica.

O mesmo ocorreu no segundo caso, em que informações imprecisas em programa de caráter jornalístico também foram capazes de criar aversão a grupo étnico, no caso os australianos de origem asiática. A ACMA considera que tal imprecisão nesse tipo de programa tem o condão de influenciar a formação de opinião da população de forma tendenciosa, eis que nem todas as informações são transmitidas ou o são em caráter distorcido.

Nesse caso, entretanto, não se tratava de um programa de caráter jornalístico, mas de um programa de comédia. E a ACMA afirmou que tais programas podem conter um humor ofensivo, desde que respeitados os ditames dos Códigos de Prática. Aqui, para a ACMA, o programa não teria o condão de influenciar a formação de opinião do público quanto ao cristianismo ou criar aversão aos seguidores dessa religião, mas tão somente de divertir o público. 
Não ficou claro para nós se a emissora poderia ser condenada caso os personagens fossem retratados nas atividades explícitas. No entanto, no período dos dois anos analisados, apesar de algumas reclamações contra programas de comédia, não houve qualquer caso em que alguma emissora privada tenha sido condenada pelo conteúdo das transmissões de programas de comédia. Tal fato nos permite concluir que programas de caráter humorístico gozam de maior proteção que os de caráter jornalístico/informativo.

O quarto caso analisado, (Asylum seekers - Regional Television Pty) refere-se ao programa jornalístico "Ten News at Five". Em 19.07.2013, foi transmitido noticiário acerca dos requerentes de asilo político, incluindo detalhes da política no âmbito dos refugiados e das reações de políticos e líderes comunitários sobre o assunto. O segmento incluiu uma manchete no início do programa, em que o apresentador anunciou a possível "solução para a invasão dos requerentes de asilo" do Primeiro-Ministro.

Então, foram apresentadas à ACMA reclamações de telespectadores no que tange a terminologia utilizada, isto é, ao uso da palavra "invasão", que poderia apenas inflamar a resposta do público e demonizar os refugiados. Segundo as reclamações, a palavra "invasores" significa pessoas que estão armadas e desejam controlar ou subjugar um país. Os reclamantes alegaram violação do art. 4.4.1 ${ }^{32}$ do Código de Prática das Emissoras de Televisão Comerciais, referente à necessidade de imparcialidade no âmbito de noticiários.

A ACMA decidiu pela não violação do dispositivo legal, desenvolvendo o seguinte raciocínio: (i) o segmento de notícias neste caso tratou de um tema atual, sendo o debate sobre os requerentes de asilo um assunto de importância pública e política; (ii) o Dicionário Macquarie define o termo "invasão" como: a. o ato de invadir ou entrar como um inimigo; b. a entrada ou advento de algo problemático ou prejudicial, como

\footnotetext{
${ }^{32}$ Art. 4.4.1: "In broadcasting news programs (including news flashes) licensees: must present news fairly and impartially."
} 
a doença; e c. entrada como se para tomar posse ou superação; (iii) o espectador razoável ordinário teria entendido a declaração introdutória como sugerindo que a Austrália está sendo invadida por requerentes de asilo; (iv) o termo "invasão" pode levar com ele associações e conotações negativas, incluindo a implicação subjacente de que os requerentes de asilo são indesejáveis ; (v) A utilização de termos particulares devem ser consideradas no contexto de um segmento na sua totalidade. A este respeito, a ACMA considerou que, de forma geral, o programa de notícias foi equilibrado, justo e imparcial, salientando em particular o seguinte: (a) um número de pontos de vista alternativos foram oferecidos e houve o debate sobre a questão durante o programa. Teve, inclusive, entrevista com ativistas em prol dos refugiados, destacando a importância do bem-estar do refugiado; (b) a linguagem utilizada pelo repórter durante o resto do segmento foi de natureza neutra e objetiva; (c) o programa não utilizou linguagem altamente carregada e não menosprezou ou incitou o medo dos telespectadores em face dos refugiados; (d) qualquer sugestão de prejuízo transportado através do título inicial estava ausente no resto do noticiário, que foi equilibrado, justo e imparcial sobre uma política tópica e controversa.

Nesse caso é interessante observar que, apesar da ACMA ter entendido que foi infeliz a utilização do termo "invasores" para os refugiados, todo o restante do programa foi neutro, objetivo e imparcial, e permitiu a livre formação de opinião daqueles que o assistiam. Vejam que um dos argumentos utilizados pela autoridade reguladora foi a promoção do debate por parte da emissora, que inclusive demonstrou pontos de vistas diferentes, alternativos e em prol dos refugiados.

O quinto e último caso (ATV Melbourne - Chinese accent) versa sobre o programa Can of Worms, que é um talk-show descrito no site da emissora como: "A cada semana, o anfitrião Chrissie Swan será acompanhado por três celebridades convidadas, para discutir o que realmente pensam sobre algumas questões morais muito complicadas. Não 
se espera que os convidados dêem uma opinião politicamente correta - nós só pedimos que eles sejam honestos, sinceros e preparados para um monte de diversão. Nenhum tópico está fora dos limites e não se pode ficar em cima do muro."

O segmento alvo da queixa envolveu três celebridades convidadas (RW, $\mathrm{CH}$ e $\mathrm{AB}$ ), participando de um jogo chamado "campo minado moral" pelo qual RW foi convidado a escolher um tema do "conselho de verdade" e responder à pergunta sobre o tema. RW escolheu o tema "raça" e o apresentador perguntou até que ponto era ofensivo para ele imitar um sotaque chinês. Em resposta, RW e, posteriormente, $A B$, imitou um sotaque chinês. Após isso AB completou "Bem, um sotaque chinês, eu acho que tudo depende do contexto, se você está fazendo isso para humilhar e desmoralizar alguém provavelmente é ofensivo. Mas se você está fazendo isso para efeito de comédia, ele funciona bem, e se ele é engraçado como $R W$ acabou de fazer, então é realmente fantástico. Se não é engraçado, então é ofensivo provavelmente."

Foi apresentada reclamação à ACMA no seguinte teor: "Fiquei surpreso ao saber da reiterada difamação racial do povo chinês por esse show. Só porque você dá ao seu show um título controverso (traduzindo-se literalmente - 'lata de minhocas'), não significa que você pode racialmente difamar uma cultura específica". O reclamante entendeu ser o programa desrespeitoso e alegou violação do art. 1.9.6 $6^{33}$ do Código de Prática das Emissoras de Televisão Comerciais. A ACMA decidiu pela não violação do dispositivo legal, desenvolvendo o seguinte raciocínio: (i) a Cláusula 1.9.6 define um limite alto para a proibição de conteúdo. As definições de "antipatia", "desprezo sério" e "ridicularizar gravemente" indicam que o Código contempla uma forte reação à transmissão do programa em questão; (ii) A ACMA considera que as declarações feitas por RW e $\mathrm{AB}$ imitando um sotaque chinês teriam sido susceptíveis de ridicularizar o povo chinês

\footnotetext{
${ }^{33}$ 1.9. A licensee may not broadcast a program, program promotion, station identification or community service announcement which is likely, in all the circumstances, to: [...] 1.9.6 provoke or perpetuate intense dislike, serious contempt or severe ridicule against a person or group of persons on the grounds of age, colour, gender, national or ethnic origin, disability, race, religion or sexual preference;"
} 
em razão da sua origem nacional. No entanto, a autoridade não considera que tal exposição ao ridículo foi grave o suficiente para que constitua uma violação do Código; (iii) Cabe notar que, enquanto o apresentador indicou que ele se sentia desconfortável com a imitação de RW de um sotaque chinês, os entrevistados manifestaram a opinião de que a questão depende do contexto. A discussão também sugeriu que o mesmo se aplica ao sentimento da utilização de outros sotaques, nomeadamente sotaques australianos e americanos; (iv) a discussão concluiu que é ofensivo usar um sotaque chinês em um contexto que se destina a rebaixar ou desmoralizar as pessoas de nacionalidade chinesa, no entanto, não é ofensivo se usado em um contexto cômico; e (v) A ACMA considera que as declarações foram feitas para efeito cômico e para os efeitos de envolver a discussão sobre o tema em apreço - a saber, o momento em que a imitação de um sotaque chinês pode ser ofensiva. $\mathrm{O}$ uso de um sotaque chinês não foi tão severo ou extremo a ponto de atingir o limiar elevado de "severo" nos termos da cláusula 1.9.6.

Não ficou muito claro para nós qual seria a definição da ACMA de "grave" ou "severo" capaz de ensejar a violação do código, mas pudemos novamente notar o tratamento diferenciado dado pela autoridade quando se trata de programa de cunho humorístico. Aliás, o referido programa retratava a opinião dos convidados, diferente de um programa de caráter jornalístico, o qual deve ter uma maior preocupação com a veracidade dos fatos.

Notamos, ainda, que em muitas decisões proferidas pela ACMA, são mencionadas e utilizadas como parâmetro as decisões anteriores, o que nos leva a crer que os entendimentos trazem algum grau de segurança jurídica sobre os temas apreciados.

É importante mencionar que entre os anos de 2013 e 2015 foram requeridas 6 (seis) revisões judiciais das decisões proferidas em esfera administrativa pela ACMA. Abaixo fizemos uma síntese dos referidos casos, cabendo ainda enfatizar o caso envolvendo a tribo Suruwaha na Amazônia que, como já mencionamos, chegou à Corte Federal australiana. 
O primeiro desses casos (ACMA v Today FM Sydney Pty Ltd) referese à investigação iniciada pela ACMA em face da rádio Today $F M$, após a transmissão de ligação telefônica que foi realizada de "brincadeira" ("trote") entre os apresentadores do programa "Verão 30" e enfermeiros do hospital King Edward VII em Londres. A ACMA iniciou a investigação para analisar se, transmitindo aquele telefonema, a Today FM teria violado uma condição da sua licença, que prevê que um licenciado não deve usar o seu serviço de radiodifusão na prática de uma infração penal. Em resposta às conclusões preliminares da ACMA, a Today FM propôs uma ação perante a Justiça Federal para fins de proibir que a ACMA continuasse a investigação. A rádio sustentou que a ACMA não está autorizada a fazer tal conclusão até que um tribunal penal julgue que houve a prática de uma infração penal e que tal conclusão (antes de um tribunal penal decidir) equivaleria a um exercício de poder inconsistente com a separação de poderes prevista na constituição. A primeira instância negou provimento ao pedido da rádio e a segunda instância reformou a decisão, entendendo por correto os argumentos da emissora. A ACMA recorreu à Suprema Corte que, por unanimidade, decidiu que a ACMA tem o poder de fazer uma determinação administrativa se entender que uma emissora cometeu um crime e tal poder existe independentemente de haver decisão na esfera criminal.

O segundo caso (ACMA v. Harbour Radio Pty Ltd) refere-se a dois processos no Tribunal Federal iniciados pela Harbour Radio, pretendendo a análise de decisões tomadas pela ACMA de iniciar investigações em face da emissora. A autoridade reguladora recebeu duas denúncias acerca de violação de códigos de prática e decidiu iniciar a investigação devido a tais denúncias, conforme sua competência estabelecida no art. 149 do $\mathrm{BSA}^{34}$. A rádio alegava que as denúncias não eram válidas. $\mathrm{O}$ tribunal confirmou que a ACMA é independente e discricionária para dar início a uma investigação, mesmo em casos em que haja dúvida sobre a validade da reclamação.

\footnotetext{
${ }^{34}$ The ACMA may investigate the complaint if the ACMA thinks that it is desirable to do so.
} 
Além dos casos apresentados, em junho de 2014 o Tribunal Federal da Austrália rejeitou três pedidos de revisão judicial dos resultados da investigação da ACMA, os quais diziam respeito a violações do Código de Práticas da Indústria da Televisão Comercial de 2010 no que tange à transmissão de notícias com precisão e apresentação de mais de um ponto de vista. Os três casos envolviam a transmissão de programas de noticiários (jornais) em que a ACMA entendeu não ter havido exatidão em relação aos fatos apresentados, bem como entendeu não terem sido apresentados pontos de vistas de forma justa. Para a ACMA, os noticiários apresentaram os fatos com extrema parcialidade.

\section{B) Alemanha}

O primeiro caso a ser destacado (MTV Music Channel vs. autoridade reguladora da Baviera - I want a famous face ${ }^{35}$ ) refere-se ao programa "I want a famous face", transmitido pela emissora MTV Music Channel, e que acompanhava as transformações de 12 jovens que recorreram à cirurgia plástica com o propósito de tornarem-se parecidos com seus respectivos ídolos.

A ideia é fazer com que o participante ficasse o mais parecido possível com seu personagem famoso favorito, através da utilização das mais variadas formas de intervenções cirúrgicas, tais como aumento de seios, lipoaspirações e injeções. Antes da transmissão do programa "I want a famous face", o órgão de autorregulação FSF (o qual já abordamos no capítulo 3 do presente trabalho, ao mencionarmos o sistema regulatório alemão) examinou os episódios e aprovou suas transmissões no período diurno. A KJM (também já mencionada acima), entretanto, decidiu pela não transmissão do programa no horário diurno e a referida decisão foi acompanhada pela autoridade reguladora do estado da Baviera, a qual anulou a aprovação da FSF.

\footnotetext{
${ }^{35}$ Urteil des VGH vom 23. März 2011 (Az. 7 BV 09.2512 und 7 BV 09.2513) DE Administrative Court ruling of 23 March 2011 (case no. 7 BV 09.2512 and 7 BV 09.2513.
} 
De acordo com as disposições legais na Alemanha, a autoridade reguladora estatal só pode derrubar a decisão da FSF se esta exceder seus poderes na tomada de decisão, ou seja, se agir em desconformidade com a lei que regula o sistema de radiodifusão. A autoridade reguladora estatal entendeu que a FSF agiu em desconformidade com a lei de proteção aos menores (Jugendschutzgesetz), e que não deveria ser aprovada transmissão do programa no período diurno, uma vez que este oferecia a impressão de que a implementação de cirurgia estética é perfeitamente comum e normal.

Segundo a autoridade reguladora, não foi encontrada abordagem crítica ou informações acerca dos riscos à saúde inerentes à intervenção cirúrgica. Pelo contrário, o programa promoveu uma atitude acrítica e positiva entre as crianças e jovens no que tange à cirurgia estética. Diante deste cenário, a autoridade publicou comunicado à imprensa com a decisão de que só poderiam ser transmitidos tais programas entre $11 \mathrm{pm}-6 \mathrm{am}$. A MTV, não conformada com a restrição na sua liberdade de programação, apelou da decisão para o Tribunal administrativo do estado da Baviera, o qual manteve a decisão administrativa da autoridade reguladora, sob o argumento de que o programa era intrinsecamente suscetível de prejudicar o desenvolvimento de crianças e jovens. A decisão sustentou que foi sugerido para os jovens, durante a sua fase de formação, de desenvolvimento de sua própria identidade, que a aparência externa é tudo que importa e que esta pode ser alterada a vontade.

De acordo com o tribunal, o programa pode gerar a impressão nas crianças e jovens de que os problemas comuns de autoestima podem ser resolvidos facilmente com um simples corte, com uma redução ou aumento do tamanho de certas partes do seu corpo, ou pela submissão à lipoaspiração e injeções. O argumento do Tribunal, similar ao da autoridade reguladora, sustentou que o programa sequer informa acerca dos prejuízos da cirurgia estética e não apresenta abordagens críticas que possam auxiliar na formação da opinião dos jovens. $\mathrm{O}$ caso em si tem importância no cenário regulatório no que tange aos aspectos da radiodifusão, pois foi a primeira vez em que a KSM divergiu da decisão da FSF. 
O caso é interessante porque o Tribunal manteve a decisão de mudança de horário de exibição, a partir de fundamentos que atingem o próprio conteúdo do programa. Ou seja, não se cogitou sequer a hipótese de proibição da exibição, apesar das críticas dirigidas ao programa em si. Nota-se uma certa deferência à liberdade de expressão em seu viés mais individual. Por outro lado, é igualmente interessante registrar a inconformidade por parte da emissora, que recorreu da decisão da KJM, insistindo assim na exibição do programa I want a famous face no período diurno.

O segundo caso (Tierbefreier vs. Germany) ${ }^{36}$ chegou a ser discutido na Suprema Corte Alemã e refere-se à transmissão de imagens obtidas ilegalmente por parte de emissora de TV.

Nesse caso, um jornalista assinou contrato de trabalho com determinada empresa, denominada no processo de "Empresa C", a qual era autorizada pela lei da Alemanha a realizar experimentos com animais (macacos), bem a como mantê-los em seu estabelecimento para esse propósito. O jornalista, durante sua jornada de trabalho, utilizando câmera escondida e sem a permissão da Empresa C, produziu 40 horas de filme com imagens documentando o tratamento dos animais no laboratório.

Após o término da relação de emprego com a Empresa C, o jornalista ofereceu o filme à uma associação de proteção aos animais, que também é emissora de televisão alemã e que transmitiu o vídeo, em duração de 20 minutos, com o título "Envenenamento por lucro". O filme continha comentários alegando que os animais eram tratados de maneira cruel e continha acusações de que a lei aplicável era desconsiderada ela empresa $\mathrm{C}$.

Além disso, a emissora publicou em sua página eletrônica mensagens apoiando os ativistas que depredaram e pintaram parte das dependências da Empresa $\mathrm{C}$, contendo frases como: "a vida de um animal é mais importante do que uma porta quebrada, um laboratório destruído ou incinerado"; "a emissora nada tem a ver com o sangue artificial colocado

\footnotetext{
${ }^{36}$ Disponível em: http://hudoc.echr.coe.int/sites/eng/pages/search.aspx?i=001-140016> acesso em 20.06.2015.
} 
por toda a empresa negociante de macacos, mas se solidariza com os ativistas que realizaram tal ato"; "a emissora protege e mantém relações com ativistas que se arriscam à acusação pública com a finalidade de salvar a vida dos animais"; "a emissora demanda imediata abolição dos experimentos com animais e não requer melhores condições ou tratamento"; "a empresa é uma assassina e torturadora".

A Empresa C, diante deste cenário, promoveu ação judicial em face da emissora e do jornalista, visando reparação dos danos causados por este último, além de requerer que a emissora não disponibilizasse o vídeo para download em seu website.

A decisão do Tribunal Constitucional, determinado que a emissora não disponibilizasse o filme para download em seu website (mesmo entendimento das instâncias inferiores), foi pautada no conceito de "regras da batalha intelectual de ideias", que, segundo o Tribunal, não teriam sido respeitadas pela emissora.

O tribunal alemão afirmou que a liberdade de expressão protegia as postagens sensacionalistas, os comentários feitos pela emissora e mesmo o fato de o material ter sido obtido de forma ilícita, considerando-se que o tema (experimentos com animais) representa uma questão controvertida e de interesse público ${ }^{37}$, restando saber, é claro, se o tribunal assume as consequências dessas afirmações sobre liberdade de expressão em casos semelhantes, o que não foi possível identificar nos limites da pesquisa realizada.

Pode-se dizer, então, que o tribunal reconhece uma proteção à liberdade de expressão a despeito do caráter sensacionalista e parcial do conteúdo. Ou seja, trata-se de um discurso efetivamente protegido, e não de mera garantia de ausência de censura prévia com uma possível (no Brasil, provável) condenação posterior. Portanto, o limite à liberdade de expressão não decorreu de seu caráter parcial, sensacionalista e/ou ofensivo à

\footnotetext{
${ }^{37}$ A título de exemplo vale mencionar o caso "Das Erste" (emissora de TV) vs. "Daimler" (a fábrica de carros), em que o jornalista assinou contrato de trabalho com a fábrica a fim de obter imagens que denunciavam a situação salarial ilegal dos trabalhadores da empresa. Neste caso o Tribunal entendeu que a relevância do tema para o debate público superava os danos sofridos pela emissora (Pressemitteilung des LG Stuttgart vom 9. Oktober 2014).
} 
empresa, o que seria um argumento frágil, mas do desrespeito às "regras da batalha intelectual" - que ocorre quando a troca pública de opiniões é suprimida por intimidação ou agitação, ou quando uma impressão distorcida é criada a partir da omissão de informações ou a partir de informações inconsistentes.

Segundo o tribunal, a emissora pode expressar sua crítica, mesmo que de forma parcial, mas, ao utilizar imagens obtidas ilegalmente, deve ao menos se preocupar com a exposição real dos fatos, sem distorcer informações. Nesse caso, levando em conta a clara intenção da empresa em influenciar o debate em seu interesse com a utilização de informações distorcidas e quebrando as regras da "batalha intelectual de ideias", a liberdade de expressão deveria ceder frente aos direitos da Empresa C. A emissora recorreu à Corte Europeia de Direitos Humanos, que, todavia, manteve a decisão, adotando basicamente os mesmos argumentos.

Interessante registrar que esta decisão não firmou entendimento sobre o uso em geral de material obtido de forma ilícita - uma questão polêmica que continua em aberto - mas o fato de o vídeo ter sido feito a partir de uma câmera escondida sem conhecimento por parte da empresa tornaria legítima uma intervenção no que seria exibido ao público. É dizer, embora as linhas editoriais, as reportagens, os programas jornalísticos sejam em regra totalmente livres, podendo, consequentemente, ser parciais, o uso de material obtido de forma ilícita relativiza essa autonomia, impondo certos ônus à emissora para que sejam respeitadas as chamadas "regras da batalha intelectual".

A decisão neste caso revelou uma tomada de posição importante na difícil e sempre polêmica tarefa de encontrar um ponto de equilíbrio entre o privado (emissoras privadas) e o público (concessões públicas), o que parece ainda ser um tabu no Brasil. E a importância da posição assumida é ainda maior por ter sido referendada pela Corte Europeia de Direitos Humanos. 
O terceiro caso (KJM vs. RTL - Die Autohändler) ${ }^{38}$ refere-se ao programa "Die Autohändler", o qual se passa numa concessionária de automóveis e que, no episódio em questão, apresentou cenas com tratamento depreciativo dos personagens principais para com duas mulheres as quais procuravam emprego de funcionárias da limpeza.

Um personagem masculino, por exemplo, subitamente jogou uma maleta em uma das mulheres, e a chamou de "Toastbrot" (um pedaço de pão) e, em seguida, referindo-se à sua aparência, perguntou se ela já havia trabalhado em um trem fantasma.

A KJM impôs multa no valor de no valor de $€ 1.005,29$ pela exibição do programa e ordenou que não fossem novamente apresentados programas nesse teor, sob o argumento de que o objetivo fundamental da educação é promover nos jovens a capacidade de aprender a respeitar o outro e o reconhecimento da igualdade entre homens e mulheres.

As mulheres foram tratadas de forma extremamente desrespeitosa, na medida em que a avaliação dos personagens acerca de suas contratações estava claramente relacionada à aparência e idade das referidas mulheres e não suas habilidades em si. Os comportamentos machistas e depreciativos exibidos no programa poderiam ser percebidos como positivos pelos jovens, além de sugerirem que o comportamento desrespeitoso e desprezível para as mulheres pertence à vida cotidiana e deve ser aceito de forma acrítica. A emissora RTL recorreu da decisão da KJM alegando violações de aspectos processuais, mas o Tribunal Administrativo rejeitou o recurso e a decisão foi mantida.

Aqui, não houve questionamento a respeito da faixa de horário, que já havia sido aprovada oportunamente pela FSK e pela KJM, pois o problema não envolvia o programa, mas um episódio específico. E como o problema era justamente o conteúdo deste episódio - considerado prejudicial à formação dos jovens vis-à-vis o objetivo da educação de

\footnotetext{
${ }^{38}$ Verwaltungsgericht Hannover, Urteil vom 6. Februar 2007 (Az.: 7 A 5469/06).
} 
promover a capacidade de aprender a respeitar o outro e o reconhecimento da igualdade entre homens e mulheres -, a questão foi levada diretamente à KJM.

O quarto e último caso (Autoridade reguladora da Baixa Saxônia vs. RTL - "Old man report" ${ }^{39}$ ) envolvia a exibição, pela emissora RTL, de cenas de maus tratos praticados por uma enfermeira num idoso de 91 anos. Tanto a autoridade reguladora da Baixa Saxônia como o tribunal administrativo (em grau de recurso) reconheceram o objetivo da reportagem de dar destaque aos problemas enfrentados por muitos idosos em situações semelhantes, mas consideraram que não era legítima a transmissão de imagens de forma estendida e detalhada em que um homem idoso impotente é submetido a maus-tratos e insultos por parte da enfermeira responsável pelos seus cuidados diários

Embora o tribunal tenha feito considerações genéricas e abrangentes a partir do princípio da dignidade da pessoa humana em sua fundamentação, como afirmar que a dignidade é violada "quando as pessoas não são mais vistas como independentes, mas são exploradas para um fim específico, como para atingir um alto índice de audiência e receita através da degradação" e que "a pessoa afetada é transportada e exposta por razões de ganância econômica", a decisão também foi específica (ou ao menos um pouco mais específica) ao reconhecer que a questão deveria ser abordada (por ser de grande importância para o debate público) sem o uso de imagens com ampla exposição de abusos e humilhações num senhor de 91 anos de idade, dependente e desamparado.

Os limites da pesquisa não permitem afirmações categóricas sobre os efeitos da decisão para casos futuros, o que demandaria outro tipo de investigação. Mas, supondo que haja uma preocupação em firmar um entendimento sobre um tema tão comum (ao menos no Brasil reportagens como essa são transmitidas com alguma frequência), é possível identificar

\footnotetext{
${ }^{39}$ Beschluss des OVG Lüneburg vom 20. Oktober 2008 (Az: 10 LA 101/07) ist abrufbar unter.
} 
na decisão o entendimento de que as emissoras não podem transmitir imagens como aquelas "de forma estendida e detalhada". Não ficou muito claro se estaria proibida a simples exibição da imagem, de forma rápida e sem exploração sensacionalista. De todo modo, parece que uma orientação ainda que mínima foi (ou teria sido) firmada a este respeito.

\section{6 - Descrição dos experimentos realizados}

Com o intuito de testarmos as autoridades reguladoras de ambos os países e entendermos realmente como uma investigação funciona na prática, isto é, como pode o telespectador realizar a reclamação, quanto tempo demora para uma resposta, e se as emissoras se envolvem no processo e dialogam, resolvemos assistir aos programas de televisão de ambos os países e enviar nossas próprias reclamações para experimentarmos o funcionamento do sistema de cada país.

Os experimentos foram realizados no âmbito do grupo de pesquisa sobre o tema regulação dos meios de comunicação - e que integra as pesquisas em desenvolvimento no Núcleo de Estudos Constitucionais da PUC-Rio.

No caso da Alemanha, o experimento foi desenvolvido em parceria com a acadêmica Renata Leal (bolsista de iniciação científica da PUC-Rio).

\section{A) Austrália}

Como já explicitamos, na Austrália, quando uma reclamação no setor da radiodifusão envolve regulação de conteúdo, é preciso que, inicialmente, seja dirigida à emissora.

Para esse contato inicial com a emissora existe um site ${ }^{40}$ centralizador, que direciona as reclamações à respectiva empresa. Então, no dia 13 de agosto de 2016, protocolamos uma reclamação no referido site,

\footnotetext{
${ }^{40}$ O site é: www.freetv.com.au. Acesso em 13.08.2016.
} 
cujo conteúdo pode ser acessado integralmente no Anexo III ao presente trabalho.

Em síntese, nossa reclamação foi dirigida à emissora Nine Entertainment co., devido à transmissão do programa A Current Affair do dia 10 de agosto de 2016, o qual versava sobre um dos procedimentos da Crioterapia, denominado "Whole-body cryotherapy". O apresentador do programa, para fins de demonstrar o procedimento, permaneceu por 5 (cinco) minutos em tubo resfriado a 140 graus negativos (Celsius), tendo o programa incluído frases como "Walt Disney foi congelado de forma similar" e "a crioterapia oxigena o sangue e limpa as sua toxinas". Além disso, o próprio título do programa era "Congele o seu peso", o que, a nosso ver, dar a entender que o método é eficaz para a perda de peso.

Dirigimos a reclamação à emissora alegando que havia sido violado o art. 3.3.1 do Código de Prática das Emissoras Comerciais, o qual estabelece que as emissoras devem transmitir elementos de fato com precisão e proporcionar diversidade de pontos de vista. Argumentamos que sequer foram apresentados os riscos possíveis da crioterapia e citamos um estudo promovido pela Universidade de Queensland, o qual enfatiza a ineficácia da crioterapia, bem como expõe os diversos riscos do método.

No dia 15/09/2016, cerca de um mês após enviarmos nossa reclamação, a emissora de TV nos respondeu, conforme consta resposta integral no Anexo IV ao presente trabalho.

Em linhas gerais, a emissora revisou a reportagem e entendeu que o programa foi preparado em consonância com o Código de Prática. Segundo a emissora, o programa foi elaborado devido à crescente popularidade da "crioterapia de corpo inteiro" nos Estados Unidos e na Austrália. O programa, então, apresentou local que oferece o método em Sydney e incluiu diversas histórias pessoais em relação à forma como o tratamento tem lhes ajudado, sendo que tais pontos de vista eram opiniões, totalmente pessoais. De acordo com a emissora, o programa não fez quaisquer 
declarações sobre a segurança da crioterapia e não tinha o intuito fornecer uma análise abrangente sobre a segurança e eficácia da crioterapia, mas tão somente de informar aos telespectadores da tendência e popularidade do método, o que está protegido pela liberdade editorial da emissora. A empresa salientou que não acredita que a pesquisa científica e médica sobre o tratamento fossem assuntos que deveriam ser discutidos dado o contexto e a natureza do programa.

Além disso, a emissora argumentou que o programa deixou claro que quaisquer benefícios potenciais da crioterapia que foram relatados eram simplesmente afirmações pessoais e não fatos fundamentados. Quanto ao título do programa, eles nos responderam que na verdade era uma pergunta "Freeze Your Weight Off?", que justamente buscava lançar a questão e o debate sobre o tema e não era uma declaração de fato.

Por fim, agradeceram que tenhamos tomado nosso tempo para enviar nossos comentários sobre a reportagem, mas pelas razões expostas, consideraram que não houve violação do Código. Ressaltaram ainda que esperavam ter esclarecido as questões, mas que, caso não estivéssemos satisfeitos, poderíamos remeter a questão à autoridade reguladora.

$\mathrm{Na}$ realidade, concordamos e ficamos satisfeitos com a resposta da emissora, que entendemos ter sido bastante completa. Foi interessante perceber que eles responderam cada questão que colocamos e ainda orientaram, ao final, da possibilidade de dirigirmos a reclamação à ACMA. Como, entretanto, o intuito do experimento era testar o sistema como um todo, prosseguimos com o teste, protocolando nossa reclamação no site da ACMA.

Para protocolar a reclamação, é necessário anexar o diálogo prévio com a emissora de televisão ou rádio e fornecer dados e endereço pessoais do denunciante. Realizamos o procedimento e, no dia seguinte, a ACMA nos respondeu informando que analisaria a reclamação e em breve nos daria um retorno. 
A resposta da ACMA, cuja integralidade pode ser vefiricada no Anexo V ao presente trabalho, foi enviada no dia 07 de outubro de 2016 e a autoridade decidiu não prosseguir com a investigação pelos seguintes motivos: (i) a narrativa da reportagem continha um grau de ceticismo sobre a eficácia do tratamento e todos os comentários em apoio à crioterapia foram apresentados como experiências pessoais ou como uma reivindicação da indústria de crioterapia, não como fato inequívoco; (ii) enquanto o jornalista Brady Halls apresentou a história, aludiu a preocupações com sua segurança pessoal ao se submeter ao procedimento; (iii) nos termos do Código de Prática, programas de atualidades podem tomar uma posição particular sobre questões. No entanto, eles devem apresentar elementos de fato com precisão e garantir que pontos de vista não foram deturpados; e (iv) a partir da avaliação inicial da ACMA acerca da transmissão, não constataram qualquer evidência de imprecisão fatual ou deturpação de pontos de vista no programa.

Todo o processo do experimento durou, portanto, dois meses e obtivemos tanto uma resposta da emissora de televisão quanto da própria ACMA, com argumentos que consideramos razoáveis.

Como realizamos apenas um experimento em cada país, não pudemos chegar a conclusões muito precisas, mas, com base na experiência australiana, consideramos ter sido resolvida a questão de forma bastante rápida, além de termos achado fácil o acesso ao sistema de protocolo de denúncias.

Além disso, conforme os casos investigados e as diversas decisões da autoridade reguladora que observamos, entendemos ter sido a decisão acima exposta coerente e de acordo com as decisões que costumam ser tomadas pela ACMA. 


\section{B) Alemanha}

No caso da Alemanha, o experimento foi desenvolvido em parceria com a acadêmica Renata Leal (bolsista de iniciação científica da PUC-Rio). Os e-mails trocados entre a acadêmica e a autoridade reguladora alemã podem ser encontrados no Anexo VI ao presente trabalho.

A reclamação foi enviada à agência reguladora MABB (Medienanstalt Berlin Brandenburg), representante do estado de Brandemburgo em 16 de novembro de 2015 e versava sobre o programa Wild Island.

O referido programa retrata a vida de 14 aventureiros confinados por quatro semanas numa ilha no Panamá, os quais devem sobreviver apenas com o auxílio de um kit de sobrevivência entregue a cada um. Os participantes, por conta própria, devem procurar comida e abrigo. O programa gerou bastante discussão na Alemanha como um todo desde o primeiro episódio por exibir cenas extremas de ostentação e matança de animais, além de inúmeras situações de sofrimento de diversos seres vivos.

Realizamos uma queixa geral sobre o programa, invocando a legislação alemã de proteção aos animais

A autoridade reguladora nos respondeu informando que o programa já foi tema de discussão pela ZAK (Kommission für Zulassung und Aufsicht - Comissão para autorização e supervisão) e, em reunião em abril de 2015, a comissão decidiu no sentido de que não houve violação por parte do programa da legislação alemã.

Em primeiro lugar, a autoridade reguladora argumentou informando que os vertebrados só eram mortos em circunstâncias necessárias e o programa adotou procedimentos como a anestesia para evitar qualquer dor ou sofrimento desses seres vivos. Ainda, os vertebrados só eram mortos por quem tinha conhecimento e habilidade necessária para realizar o procedimento de forma indolor. Quanto aos caracóis e caranguejos, a 
MABB nos informou que suas mortes são inquestionáveis, eis que estes animais não são vertebrados e, portanto, não encontram a mesma proteção na lei.

A MABB disse ainda que não havia que se discutir a matança de peixes, porque as ações reproduzidas não iam além da pesca de costume. A autoridade ressaltou que, segundo o organizador do programa, os participantes também foram informados sobre como os animais devem ser mortos, a fim de evitar a dor desnecessária.

Nesse caso, apesar de não concordarmos com os propósitos do programa, não pudemos identificar violações da legislação alemã sobre a radiodifusão. O programa sequer era transmitido em horário passível de ser assistido por crianças, motivo pelo qual entendemos a decisão da autoridade reguladora como correta.

É interessante ver, entretanto, como o referido programa fomentou o debate público acerca do tratamento destinado aos animais, bem como tem gerado discursos mais ativos no sentido inclusive de uma possível modificação da legislação alemã de proteção aos animais, considerada por alguns como retrógrada.

\section{7 - Conclusão}

É extremamente importante que as sociedades democráticas tenham uma ampla gama de meios independentes e autônomos de comunicação, que sejam capazes de refletir a diversidade de ideias e opiniões. Tanto Austrália como Alemanha afirmam que as liberdades de expressão e de informação constituem direitos essenciais de seus respectivos ordenamentos jurídicos e reconhecem a importância da radiodifusão para a garantia desses direitos.

Todavia, também observamos que é essencial a procura de um equilíbrio entre liberdade de expressão e regulação da radiodifusão, sendo vital que as regras sejam codificadas para permitir que empresas de 
radiodifusão, telespectadores e ouvintes, saibam onde estão os limites de aceitabilidade. Sujeitas a estas regras, às emissoras deve ser assegurada a independência editorial, para transmitirem livre de interferência ou censura por parte do Estado ou de qualquer órgão regulador.

Vimos que os exemplos na Alemanha e Austrália são particularmente interessantes, devido à sua ênfase na representação comunitária. Ao invés de focar na imparcialidade, o modelo regulatório de ambos os países busca equilibrar os diferentes interesses da comunidade permitindo que diversos grupos (como igrejas, sindicatos, etc.) indiquem, no caso da Alemanha, representantes para trabalhar no monitoramento das autoridades reguladoras regionais e, no caso da Austrália, participem da elaboração dos Códigos de Prática responsáveis pela regulação conteudística.

Os referidos sistemas regulatórios, portanto, são pautados por interesses diferenciados e tal diversidade contribui para a imparcialidade das decisões e a independência das instituições como um todo. Ao contrário dos mecanismos reguladores que pretendem se isolar de qualquer viés, os modelos estudados internalizam as tendências de diferentes grupos sociais. Ambos os países buscaram reconhecer o papel da mídia de promotor e garantidor da livre formação de opinião, através da criação em seus sistemas legais de meios que promovessem a pluralidade de informações e perspectivas.

Como demonstramos, as diretrizes a serem observadas pelas emissoras envolvem pontos como, por exemplo, o dever de assegurar pluralidade de opiniões e participação de grupos minoritários, em especial nas áreas de cultura, informação e educação; quotas de produção regional; limites a propagandas comerciais; direito de resposta; além de uma proteção destacada aos direitos das crianças.

É importante reconhecer que o tema envolvendo a regulação da mídia não se trata de algo simples, uma vez que não é fácil estabelecer um ponto de equilíbrio entre a liberdade de expressão e a intervenção estatal legítima. 
No entanto, pudemos observar, tanto com a análise do sistema regulatório alemão, quanto com a análise do sistema australiano, que os países não só debatem o tema como procuram impor limites ao conteúdo das emissoras, sem provocar qualquer ideia de censura.

Como vimos, são poucos os casos que chegam à esfera judicial, o que sugere algum consenso quanto aos limites impostos pelas autoridades reguladoras e, conforme observamos nas decisões proferidas, em muitos casos são mencionadas decisões anteriores, o que nos leva a crer que os entendimentos trazem algum grau de segurança jurídica sobre os temas apreciados.

Por fim, embora seja interessante investigar posições críticas acerca do sistema regulatório da mídia em outros países, propomos que também é interessante o início do debate sobre o tema no Brasil, sem objeções frágeis (como a possível censura) e assumindo como premissa que algum grau de regulação é fundamental numa sociedade democrática ${ }^{41}$.

\footnotetext{
${ }^{41}$ LEITE, Fábio. Regulação dos meios de comunicação e o desafio do controle de conteúdo: dificuldades no Brasil e algumas contribuições da Alemanha.
} 


\section{8 - Referências}

Australian Communications and Media Authority. International approaches to audiovisual content regulation - A comparative analysis of the regulatory frameworks. May 2001. Disponível em: http://www.acma.gov.au/webwr/_assets/main/lib310665/international_appr oaches_to_av_content_reg.pdf. Acesso em 20 de fevereiro de 2015.

Banco de dados da Australian Communications and Media Authority. Disponível em http://www.acma.gov.au/. Acesso em 20.10.2015.

Banco de Dados do Merlin Observatory, disponível em <http://merlin.obs.coe.int/> acesso em 20.06.2015.

Broadcasting Services Act 1992. Disponível em: www.austlii.edu.au. Acesso em 20.07.2016.

Broadcasting Legislation Amendment (Media Reform) Bil 2016. Disponível em: www.aph.gov.au. Acesso em 20.07.2016.

CALDERARO, Andrea / DOBREVA Alina. European Union Competences in respect of media pluralism and media freedom. Centre for Media Pluralism and Media Freedom at the Robert Schuman Centre for Advanced Studies, EUI, RSCAS PP 2013/01, 2013, p. 11

Código de Ética de Emissoras Canadenses. Disponível em http://www.cbsc.ca/english/codes/cabethics. Acesso em 15.07.2015.

Convenção Europeia sobre Televisão Transfronteiras. Disponível em http://www.book.coe.int/conv/en/ui/frm/fl32-e.htm. Acesso em 05.07.2015.

DI PIETRO, Maria Sylvia. Direito Administrativo.15.ed. São Paulo: Atlas, 2003, p. 402. 
FISCH, Shalom M. Children's learning from educational television, Seasame Street and beyond. Erlbaum, Mahwalh, New Jersey, 2004.

Foreign Law Translation. University of Texas. Disponível em www.law.utexas.edu/transnational/foreign-lawtranslations/german/case.php?id=641. Acesso em 16.05.2015.

HUMPHREYS, Peter. The goal of pluralism and the ownership rules for private broadcasting in Germany: regulation or de-regulartion?Ed Dyson, K, 1 05-135. Dartmouth, 1998.

Interstate Broadcasting Treaty (Rundfunkstaatsvertrag). Disponível em: http://attorney.bei.t-online.de/060021.htm. Acesso em 14.06.2015.

LEITE, F. C. . Regulação dos meios de comunicação e o desafio do controle de conteúdo: dificuldades no Brasil e algumas contribuições da Alemanha. In: Bello, E.; Ribeiro, S.M.. (Org.). Democracia e meios de comunicação: pluralismo, liberdade de expressão e informação. 1ed.Rio de Janeiro: Lumen Juris, 2016.

MISRA, P.K. Educational Television Broadcasting in Germany: prevailing practices, existing challenges and adoptable policies. Eleed, Iss. 6. 2010. Disponível em: www.eleed.campussoub.de

Oxford Pro Bono. Comparative Hate Speech Law: ANNEXURE - Research prepared for the Legal Resources Centre, South Africa. University of Oxford, 2012. Disponível em http://www.law.ox.ac.uk/opbp. Acesso em: 02.05.2015.

PEERS, Steve / HERVEY, Tamara / KENNER, Jeff / WARD, Angela. The EU Charter of Fundamental Rights. A commentary. Hart Publishing, 2014.

Protection of Young Persons Act (Jugendschutzgesetz). Disponível em: http://www.bmfsfj.de/RedaktionBMFSFJ/Abteilung5/PdfAnlagen/juSchGenglisch,property=pdf,bereich $=, r w b=$ true.pdf. Acesso em 02.07.2015. 
REZENDE, Renato Monteiro de. Direitos Prestacionais de Comunicação. São Paulo: Saraiva, 2014, 339p.

SALOMON, Eve. Guidelines for Broadcasting Regulation. 2. ed. Londres: Commonwealth Broadcasting Association, 2008.

SALOMON, Eve /MENDEL, Toby. $O$ ambiente regulatório para a radiodifusão: uma pesquisa de melhores práticas para os atores-chave brasileiros. Organização das Nações Unidas para a Educação, a Ciência e a Cultura - UNESCO. Série Debates CI, nº 7 - fevereiro, 2011.

SANKIEVICZ, Alexandre. Liberdade de Expressão e Pluralismo Perspectivas de Regulação. São Paulo: Saraiva, 2011, 225p.

SHAUER, Frederick. Free Speech: a philosophical enquiry. Camridge: Cabridge University Press, 1982.

VOORHOOF Dirk. The right to freedom of expression and information under the European Human Rights System: towards a more transparent democratic society. Centre for Media Pluralism and Media Freedom, EUI, RSCAS 2014/12, pp. 4, 10.

WALLIN, Claudia. “Como a mídia é regulada na Suécia”. Disponível em http://www.diariodocentrodomundo.com.br/como-a-midia-e-regulada-nasuecia/. Acesso em 03/06/2016.

WARD, David. A mapping study of media concentration and ownership in ten European countries. Commissariaat voor de Media. Netherlands, 2004.

WOLFANG Schulz/UWE Jurgens/THORSTEN Hels/STEPHAN Dreyer: Regulation of Broadcasting and Internet Services in Germany. Hamburg. Verlag Hans-Bredow-Institut, Outubro 2002, $1^{\text {a }}$ edição. 


\section{9 - Anexos}

\section{Anexo I - Tabela de casos Austrália - Study's case table Australia)}

\begin{tabular}{|c|c|c|c|}
\hline Call Sign & $\begin{array}{l}\text { Program } \\
\text { Name }\end{array}$ & Description & Outcome \\
\hline TVQ & House of Lies & $\begin{array}{l}\text { Depictions of sexual activity } \\
\text { inappropriate for PG classified } \\
\text { program promotion during a } \\
\text { sporting event. }\end{array}$ & $\begin{array}{l}\text { No Breach-Restrictions in } \mathrm{G} \\
\text { or PG programs at } 8.30 \mathrm{pm} \text {; } \\
\text { Promotions for programs } \\
\text { classified MA or AV }\end{array}$ \\
\hline NRN & $\begin{array}{l}2012 \text { Melbourne } \\
\text { Comedy } \\
\text { Festival }\end{array}$ & $\begin{array}{l}\text { Hate speech against } \\
\text { Christians. }\end{array}$ & $\begin{array}{l}\text { No Breach-Dislike, } \\
\text { contempt or ridicule }\end{array}$ \\
\hline TCN & A Current Affair & $\begin{array}{l}\text { No factual foundation for } \\
\text { allegations } \\
\text { entrepreneurs, breach of } \\
\text { privacy, and complaints } \\
\text { handling. }\end{array}$ & $\begin{array}{l}\text { Breach-Accurate broadcast } \\
\text { of factual material (clause } \\
4.3 .1 \text { of the Free TV Code). } \\
\text { No Beach-Several other } \\
\text { statements under clause 4.3.1. } \\
\text { Breach - Clause 4.3.5 } \\
\text { (privacy). No Beach-Clause } \\
4.5 \text { (accuracy in promotions). } \\
\text { Breach-Complaints-handling }\end{array}$ \\
\hline ATV & Couch Time & $\begin{array}{l}\text { Anti-Christian emblem } \\
\text { (inverted cross) worn by host } \\
\text { offensive to Christian faith. }\end{array}$ & $\begin{array}{l}\text { No Breach-Dislike, } \\
\text { contempt or ridicule }\end{array}$ \\
\hline ATN & Today Tonight & $\begin{array}{l}\text { Insensitivity towards widow } \\
\text { and invasion of privacy in } \\
\text { segment about influenza death. }\end{array}$ & $\begin{array}{l}\text { No Breach-Appropriate } \\
\text { regard; Privacy; Exercise } \\
\text { sensitivity }\end{array}$ \\
\hline HSV & $\begin{array}{l}\text { Channel Seven } \\
\text { News }\end{array}$ & $\begin{array}{l}\text { Sensationalism, religious } \\
\text { vilification and lack of fairness } \\
\text { in item about ethno botanical } \\
\text { plant nursery. }\end{array}$ & $\begin{array}{lr}\text { No } & \text { Breach-Dislike, } \\
\text { contempt or ridicule; Public } \\
\text { panic; } \quad \text { Fairness and } \\
\text { impartiality }\end{array}$ \\
\hline HSV & $\begin{array}{l}\text { Weekend } \\
\text { Sunrise }\end{array}$ & $\begin{array}{l}\text { Inaccurate statements about } \\
\text { weight loss product; on-air } \\
\text { correction was not adequate. }\end{array}$ & $\begin{array}{l}\text { No Breach-Accuracy; } \\
\text { Correction of errors }\end{array}$ \\
\hline STQ & $\begin{array}{l}\text { Home and } \\
\text { Away }\end{array}$ & $\begin{array}{l}\text { Several story lines contained } \\
\text { drug references inappropriate } \\
\text { for a PG classified program. }\end{array}$ & $\begin{array}{l}\text { No Breach-Classification of } \\
\text { material }\end{array}$ \\
\hline NBN & A Current Affair & $\begin{array}{l}\text { Inappropriate depictions of } \\
\text { nudity and sexual activity not } \\
\text { suitable for broadcast during a } \\
\text { current affairs program. }\end{array}$ & $\begin{array}{l}\text { No Breach-Classification } \\
\text { exemption for news and } \\
\text { current affairs programs }\end{array}$ \\
\hline SAS & Today Tonight & Error of fact. & No Breach-F \\
\hline HSV & $\begin{array}{l}\text { World's Wildest } \\
\text { Police Videos: } \\
\text { Hotel Hostage } \\
\text { Horror }\end{array}$ & $\begin{array}{l}\text { Depictions of violence } \\
\text { inappropriate for } \mathrm{M} \text { classified } \\
\text { program. }\end{array}$ & $\begin{array}{l}\text { No Breach-Classification of } \\
\text { material }-\mathrm{M}\end{array}$ \\
\hline ATV & $\begin{array}{l}\text { Snog Marry } \\
\text { Avoid }\end{array}$ & $\begin{array}{ll}\text { Promotion } & \text { contained } \\
\text { inappropriate coarse language. }\end{array}$ & $\begin{array}{l}\text { No Breach-Classification of } \\
\text { material - PG }\end{array}$ \\
\hline STW & Underbelly & glorified and & No Breach-Classification of \\
\hline
\end{tabular}




\begin{tabular}{|c|c|c|c|}
\hline Call Sign & $\begin{array}{l}\text { Program } \\
\text { Name }\end{array}$ & Description & Outcome \\
\hline & Squizzy & $\begin{array}{l}\text { promoted violence and was } \\
\text { inappropriate for PG time } \\
\text { zone. }\end{array}$ & material - PG \\
\hline WIN & WIN News & $\begin{array}{l}\text { Inaccurate information about } \\
\text { measles vaccination. }\end{array}$ & $\begin{array}{l}\text { No Breach-Clause } 4.3 .1 \text { to } \\
\text { the use of the term "choice } \\
\text { group" or plural "choice } \\
\text { groups" }\end{array}$ \\
\hline STQ & $\begin{array}{l}\text { Seven Local } \\
\text { News }\end{array}$ & $\begin{array}{l}\text { Inaccurate date given for a } \\
\text { falling power pole incident. } \\
\text { Complaint handling. }\end{array}$ & $\begin{array}{l}\text { No Breach-Factual accuracy; } \\
\text { Complaint handling }\end{array}$ \\
\hline TVW & Today Tonight & $\begin{array}{l}\text { False and misleading } \\
\text { information, and unfair } \\
\text { generalisations, in segment } \\
\text { about pharmacy survey. }\end{array}$ & $\begin{array}{l}\text { No Breach-Factual accuracy; } \\
\text { Unfair identification }\end{array}$ \\
\hline TEM & The Project & $\begin{array}{l}\text { Information reported on was } \\
\text { incorrect. }\end{array}$ & No Breach—Factual accuracy \\
\hline HSV & Seven News & $\begin{array}{l}\text { Racial vilification of Korean } \\
\text { people. }\end{array}$ & $\begin{array}{l}\text { No Breach-Dislike, } \\
\text { contempt or ridicule }\end{array}$ \\
\hline HSV & Seven News & $\begin{array}{l}\text { Distress to viewers and } \\
\text { relatives in item about train } \\
\text { accident fatality, and } \\
\text { complaints handling. }\end{array}$ & $\begin{array}{l}\text { No } \quad \text { Breach-Appropriate } \\
\text { regard }\end{array}$ \\
\hline TCN & $\begin{array}{c}\text { Cricket - } \\
\text { Australia vs } \\
\text { South Africa } \\
\end{array}$ & $\begin{array}{l}\text { Promotion of beer brand } \\
\text { without disclosure. }\end{array}$ & $\begin{array}{l}\text { No Breach-Promotional } \\
\text { material }\end{array}$ \\
\hline GTV & 60 Minutes & $\begin{array}{l}\text { Segment on Syria contained } \\
\text { inaccuracies, was not } \\
\text { presented with care, and } \\
\text { complaints }\end{array}$ & $\begin{array}{l}\text { No Breach-Exercise care in } \\
\text { selection of material; Factual } \\
\text { accuracy; Correction of } \\
\text { significant errors; Complaint } \\
\text { handling }\end{array}$ \\
\hline GTV & A Current Affair & $\begin{array}{l}\text { Untrue statement in segment } \\
\text { about a business dispute. }\end{array}$ & $\begin{array}{l}\text { No Breach of clause } 4.3 .1 \\
\text { (factual accuracy) }\end{array}$ \\
\hline BTQ & Sunrise & $\begin{array}{l}\text { Offensive and inaccurate } \\
\text { comments about public } \\
\text { breastfeeding. }\end{array}$ & $\begin{array}{l}\text { No Breach of clauses } 4.3 .1 \\
\text { [Factual accuracy]; } 1.9 .6 \\
\text { [Contempt on grounds of } \\
\text { gender] }\end{array}$ \\
\hline QTQ & A Current Affair & $\begin{array}{l}\text { Inaccuracies and unfair } \\
\text { association in segment } \\
\text { 'Stealing from seniors' }\end{array}$ & No Breach-Accuracy \\
\hline ATV & The Project & $\begin{array}{l}\text { Factual inaccuracy in segment } \\
\text { 'Gun Comeback'. }\end{array}$ & No Breach-Factual accuracy \\
\hline TCN & $\begin{array}{l}\text { Channel Nine } \\
\text { News }\end{array}$ & $\begin{array}{l}\text { Use of material recorded with } \\
\text { aid of listening device at 'Mad } \\
\text { Monday' celebration. }\end{array}$ & $\begin{array}{l}\text { No Breach-Paragraph } \\
7(1)(\text { h) of Schedule } 2 \text { to the } \\
\text { BSA (use of a broadcasting } \\
\text { service in the commission of } \\
\text { an offence) }\end{array}$ \\
\hline SDW & NCIS & $\begin{array}{l}\text { Promotion exceeded mild } \\
\text { impact and was not suitable } \\
\text { for PG time zone. }\end{array}$ & $\begin{array}{l}\text { No Breach-Classification of } \\
\text { other material - PG }\end{array}$ \\
\hline GTV & 60 Minutes & $\begin{array}{l}\text { Promotions exceeded mild } \\
\text { impact and were not suitable } \\
\text { for PG time zone. }\end{array}$ & $\begin{array}{l}\text { No Breach-Classification of } \\
\text { Other Material - PG }\end{array}$ \\
\hline
\end{tabular}




\begin{tabular}{|c|c|c|c|}
\hline Call Sign & $\begin{array}{l}\text { Program } \\
\text { Name }\end{array}$ & Description & Outcome \\
\hline STQ & $\begin{array}{l}\text { Seven Local } \\
\text { News }\end{array}$ & $\begin{array}{l}\text { Distorted and inaccurate item } \\
\text { about foreshore protest. }\end{array}$ & $\begin{array}{l}\text { No Breach-Factual accuracy; } \\
\text { Impartiality }\end{array}$ \\
\hline HSV & $\begin{array}{l}\text { Weekend } \\
\text { Sunrise }\end{array}$ & $\begin{array}{l}\text { Misleading claims about } \\
\text { climate change and polar } \\
\text { bears. }\end{array}$ & No Breach-Factual accuracy \\
\hline SAS & Today Tonight & $\begin{array}{l}\text { Simulation of events, } \\
\text { transmitting messages below } \\
\text { or near the threshold of normal } \\
\text { awareness, accuracy, and } \\
\text { privacy. }\end{array}$ & $\begin{array}{l}\text { No Breach of clauses } 4.3 .1 \text {, } \\
4.3 .5,4.5,1.9 .1 \text { and } 1.9 .4 \text { of } \\
\text { the Commercial Television } \\
\text { Industry Code of Practice } \\
2010\end{array}$ \\
\hline SAS & Today Tonight & $\begin{array}{l}\text { Inaccuracies in segment about } \\
\text { mobility scooter safety. }\end{array}$ & No Breach-Factual accuracy \\
\hline $\mathrm{ABN}$ & ABC News 24 & $\begin{array}{l}\text { Use of Christian images in } \\
\text { news item about the Royal } \\
\text { Commission into child sexual } \\
\text { abuse was offensive and } \\
\text { demonstrated bias. }\end{array}$ & $\begin{array}{l}\text { No Breach-4.1 [Impartiality] } \\
\text { or } 7.1 \text { [Harm and offence] }\end{array}$ \\
\hline TDT & $\begin{array}{l}\text { The Biggest } \\
\text { Loser: Next } \\
\text { Generation }\end{array}$ & $\begin{array}{l}\text { Promotion contained } \\
\text { demeaning, exploitative, } \\
\text { threatening and offensive } \\
\text { language and behaviour. }\end{array}$ & $\begin{array}{l}\text { No Breach-Proscribed } \\
\text { Material and Classification of } \\
\text { Other Material - PG }\end{array}$ \\
\hline HSV & Today Tonight & $\begin{array}{l}\text { Inaccurate portrayal of a } \\
\text { marginalised individual }\end{array}$ & No Breach-Factual accuracy \\
\hline ATN & Today Tonight & $\begin{array}{l}\text { Inappropriate report on the } \\
\text { sale of legal drugs at a time } \\
\text { when children could be } \\
\text { watching. }\end{array}$ & $\begin{array}{l}\text { No Breach of Clause 2.4.1 } \\
\text { [Exemption for News and } \\
\text { Current Affairs and broadcasts } \\
\text { of sporting events] }\end{array}$ \\
\hline ATV & Can of Worms & Ridicule on basis of race. & $\begin{array}{l}\text { No Breach of clause } 1.9 .6 \\
\text { [dislike, contempt or ridicule } \\
\text { on grounds of national or } \\
\text { ethnic origin] }\end{array}$ \\
\hline ATN & Today Tonight & $\begin{array}{l}\text { Inaccuracies in segment } \\
\text { 'Jewellers break the law'. }\end{array}$ & $\begin{array}{l}\text { No Breach of clause } 4.3 .1 \\
\text { [Factual accuracy] }\end{array}$ \\
\hline SAS & Today Tonight & $\begin{array}{l}\text { Person's privacy invaded by } \\
\text { broadcasting footage filmed at } \\
\text { their workplace. }\end{array}$ & $\begin{array}{l}\text { No Breach-Clauses 2.4.1 } \\
\text { [Exercising due care in } \\
\text { selecting material for } \\
\text { broadcast] and } 4.3 .5 \text { [Privacy] }\end{array}$ \\
\hline SAS & Sunrise & $\begin{array}{l}\text { Promotion of product during } \\
\text { interview. }\end{array}$ & $\begin{array}{l}\text { No breach of clauses 1.18, } \\
1.20 \text { and } 1.21\end{array}$ \\
\hline ATN & Family Guy & $\begin{array}{l}\text { Distasteful and offensive } \\
\text { treatment of the Christian God. }\end{array}$ & $\begin{array}{l}\begin{array}{l}\text { No Breach of clause } 1.9 .6 \\
\text { (proscribed material) of } \\
\text { of }\end{array} \\
\text { the Commercial Television } \\
\text { Industry Code of Practice } \\
2010\end{array}$ \\
\hline BTQ & $\begin{array}{c}\text { Seven News, } \\
\text { Today Tonight, } \\
\text { Home and } \\
\text { Away }\end{array}$ & Quality of captions & $\begin{array}{l}\text { Disregarded Breach - Looping } \\
\text { Captions }\end{array}$ \\
\hline GTV & A Current Affair & $\begin{array}{l}\text { Omission of information in } \\
\text { segment about parking on } \\
\text { nature strips. }\end{array}$ & $\begin{array}{l}\text { No Breach-Clause } \\
\text { (Factual accuracy) }\end{array}$ \\
\hline SAS & $\begin{array}{l}\text { A Place to Call } \\
\text { Home }\end{array}$ & 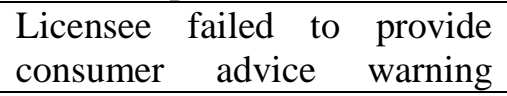 & $\begin{array}{l}\text { No Breach-Classification of } \\
\text { Other Material - M and }\end{array}$ \\
\hline
\end{tabular}




\begin{tabular}{|c|c|c|c|}
\hline Call Sign & $\begin{array}{l}\text { Program } \\
\text { Name }\end{array}$ & Description & Outcome \\
\hline & & $\begin{array}{l}\text { viewers of elements relating to } \\
\text { sex and violence. }\end{array}$ & $\begin{array}{l}\text { Consumer Advice for Certain } \\
\text { Programs }\end{array}$ \\
\hline TCN & A Current Affair & $\begin{array}{lr}\text { Inaccuracies } & \text { and negative } \\
\text { portrayal in 'All-Asian Mall' } \\
\text { segment; } \\
\text { correction. }\end{array}$ & $\begin{array}{l}\text { Breach-Factual accuracy; } \\
\text { Negative light by gratuitous } \\
\text { emphasis on ethnic origin; } \\
\text { Provoke intense dislike and } \\
\text { serious contempt on grounds } \\
\text { of ethnic origin. No Breach- } \\
\text { Create public panic }\end{array}$ \\
\hline TVQ & $\begin{array}{l}\text { Ten News At } \\
\text { Five }\end{array}$ & $\begin{array}{l}\text { Inaccurate description of } \\
\text { person as an 'expert' on } \\
\text { climate change. }\end{array}$ & $\begin{array}{l}\text { No Breach of clauses } 4.3 .1 \\
\text { [Factual accuracy]; 4.4.1 } \\
\text { [Present news fairly and } \\
\text { impartially]. Breach of clause } \\
7.12 \text { [Complaint handling] }\end{array}$ \\
\hline HSV & Today Tonight & Photograph of person shown & $\begin{array}{l}\text { No Breach-Material relating } \\
\text { to a person's personal and } \\
\text { private affairs }\end{array}$ \\
\hline TCN & $\begin{array}{l}\text { NRL Footy } \\
\text { Show }\end{array}$ & $\begin{array}{l}\text { Inappropriate references to } \\
\text { children in a } \mathrm{M} \text { classified } \\
\text { program. }\end{array}$ & $\begin{array}{l}\text { No Breach-Classification of } \\
\text { other material }-\mathrm{M}\end{array}$ \\
\hline ATV & Bish's Biz & $\begin{array}{l}\text { Inaccurate reference to Portia } \\
\text { de Rossi as Ellen DeGeneres' } \\
\text { 'wife'. }\end{array}$ & No Breach-Accuracy \\
\hline ATV & $\begin{array}{c}\text { Political } \\
\text { advertisement }\end{array}$ & $\begin{array}{l}\text { Political advertisement } \\
\text { broadcast without required } \\
\text { particulars. }\end{array}$ & $\begin{array}{l}\text { Breach-Announced of } \\
\text { required particulars in political } \\
\text { advertising }\end{array}$ \\
\hline TCN & advertisement & $\begin{array}{l}\text { Political advertisement } \\
\text { broadcast without required } \\
\text { particulars. }\end{array}$ & $\begin{array}{l}\text { No breach of paragraph } 7(1)(\mathrm{j}) \\
\text { of Schedule } 2 \text { to } \\
\text { the Broadcasting } \\
1992\end{array}$ \\
\hline QTQ & 60 Minutes & $\begin{array}{l}\text { Inaccuracies, invasion of } \\
\text { privacy, broadcast of secretly- } \\
\text { recorded conversation, and } \\
\text { contempt for an Amazonian } \\
\text { indigenous community }\end{array}$ & $\begin{array}{l}\text { No Breach-Accuracy; } \\
\text { Privacy; Racial vilification; } \\
\text { Use of broadcasting service in } \\
\text { the commission of an offence }\end{array}$ \\
\hline QTQ & Nine News & $\begin{array}{l}\text { Inappropriate level of detail } \\
\text { regarding an extra-marital } \\
\text { affair at a time when young } \\
\text { people likely to be watching. }\end{array}$ & $\begin{array}{l}\text { No Breach of Clause } 2.4 .1 \\
\text { [Exemption for News and } \\
\text { Current Affairs and broadcasts } \\
\text { of sporting events] }\end{array}$ \\
\hline TCN & $\begin{array}{c}\text { Hamish and } \\
\text { Andy Gap Year } \\
\text { Asia } \\
\end{array}$ & $\begin{array}{l}\text { Footage of animal cruelty in a } \\
\text { PG classified program with no } \\
\text { consumer advice. }\end{array}$ & $\begin{array}{l}\text { No Breach-Classification of } \\
\text { other material - PG (Themes) } \\
\text { and consumer advice }\end{array}$ \\
\hline TVQ & $\begin{array}{c}\text { Ten News At } \\
\text { Five }\end{array}$ & $\begin{array}{l}\text { Reference to asylum seekers } \\
\text { as an 'invasion' was not } \\
\text { balanced and impartial. }\end{array}$ & No Breach-Impartiality \\
\hline TCN & Advertisement & $\begin{array}{ll}\begin{array}{l}\text { Broadcast } \\
\text { advertisement }\end{array} & \text { tobacco } \\
\end{array}$ & No Breach-Advertisement \\
\hline BTQ & $\begin{array}{l}\text { Weekend } \\
\text { Sunrise }\end{array}$ & $\begin{array}{l}\text { Segment about eco friendly } \\
\text { cars was inaccurate and } \\
\text { biased. }\end{array}$ & No Breach-Accuracy \\
\hline TEM & Ripper Street & $\begin{array}{l}\text { Inappropriate depictions of sex } \\
\text { and violence not suitable for a } \\
\text { program promotion broadcast }\end{array}$ & $\begin{array}{l}\text { Breach-Classification of } \\
\text { other material. } \\
\text { Breach-Restrictions in } G\end{array}$ \\
\hline
\end{tabular}




\begin{tabular}{|c|c|c|c|}
\hline Call Sign & $\begin{array}{l}\text { Program } \\
\text { Name }\end{array}$ & Description & Outcome \\
\hline & & during a G-classified program. & $\begin{array}{l}\text { viewing periods and in certain } \\
\text { other } G \text { programs }\end{array}$ \\
\hline $\begin{array}{c}\text { SAS } \\
\text { Adelaide }\end{array}$ & Today Tonight & $\begin{array}{l}\text { Segment on a family's use of } \\
\text { royal titles and related } \\
\text { program promotions was } \\
\text { inaccurate, misrepresented } \\
\text { viewpoints and breached } \\
\text { privacy. }\end{array}$ & $\begin{array}{l}\text { No Breach of clauses } 4.3 .1 \\
\text { [factual accuracy, fair } \\
\text { representation of viewpoints], } \\
4.3 .5 \text { [privacy], or } 4.5 \\
\text { [accuracy in promotions] of } \\
\text { the Commercial Television } \\
\text { Industry Code of Practice } \\
2010\end{array}$ \\
\hline HSV & The Blacklist & $\begin{array}{l}\text { Inappropriate depictions of } \\
\text { violence in } \mathrm{M} \text { classified } \\
\text { program. }\end{array}$ & $\begin{array}{l}\text { No Breach-Classification of } \\
\text { other material } \\
\text { No Breach-Material Not } \\
\text { Suitable for Television } \\
\end{array}$ \\
\hline $\begin{array}{l}\text { Commercial } \\
\text { TV }\end{array}$ & TVW & Motor Mate & Tobacco advertisements \\
\hline $\begin{array}{l}\text { SAS } \\
\text { Adelaide }\end{array}$ & $\begin{array}{l}\text { The Morning } \\
\text { Show }\end{array}$ & $\begin{array}{l}\text { Inappropriate depictions of } \\
\text { sexual activity in } M \text { classified } \\
\text { program }\end{array}$ & $\begin{array}{l}\text { No breach-classification of } \\
\text { other material }\end{array}$ \\
\hline $\begin{array}{l}\text { ATV } \\
\text { Melbourne }\end{array}$ & $\begin{array}{l}\text { The Biggest } \\
\text { Loser: The Next } \\
\text { Generation }\end{array}$ & $\begin{array}{l}\text { Provocation of dislike and } \\
\text { presentation of participants in } \\
\text { reality TV concerning weight } \\
\text { loss }\end{array}$ & $\begin{array}{l}\text { No breach of clause } 1.9 .6 \\
\text { [provoke or perpetuate intense } \\
\text { dislike, serious contempt or } \\
\text { severe ridicule on the grounds } \\
\text { of disability] or clause } 1.9 .7 \\
\text { [present participants in reality } \\
\text { TV programs in a highly } \\
\text { demeaning or highly } \\
\text { exploitative manner] of } \\
\text { the Commercial Television } \\
\text { Industry Code of Practice } \\
2010\end{array}$ \\
\hline $\begin{array}{l}\mathrm{CBN} \\
\text { (Southern } \\
\text { NSW) }\end{array}$ & $\begin{array}{l}\text { Weekend } \\
\text { Sunrise }\end{array}$ & $\begin{array}{l}\text { Inaccuracy in discussion on } \\
\text { measles immunisation }\end{array}$ & $\begin{array}{l}\text { No breach of clause } 4.3 .1 \\
\text { [factual accuracy] of } \\
\text { the Commercial } \\
\text { Industry Code of } \\
2010\end{array}$ \\
\hline$\overline{\text { GWN }}$ & Seven News & $\begin{array}{l}\text { Misleading and violent footage } \\
\text { in news segment }\end{array}$ & $\begin{array}{l}\text { No breach of the Commercial } \\
\text { Television Industry Code of } \\
\text { Practice } 2010\end{array}$ \\
\hline $\begin{array}{l}\text { STQ } \\
\text { (Regional } \\
\text { Qld) }\end{array}$ & $\begin{array}{l}\text { Seven Local } \\
\text { News }\end{array}$ & $\begin{array}{l}\text { Invasion of privacy concerning } \\
\text { a child }\end{array}$ & $\begin{array}{l}\text { No breach of clauses } 4.3 .5 \\
\text { [privacy] and } 4.3 .5 .2 \text { [privacy } \\
\text { of a child] of the Commercial } \\
\text { Television Industry Code of } \\
\text { Practice 2010 }\end{array}$ \\
\hline HSV & Today Tonight & $\begin{array}{l}\text { Inaccuracies in a segment } \\
\text { concerning a dermal laser } \\
\text { clinic }\end{array}$ & $\begin{array}{l}\text { No breach of clause } 4.3 .1 \\
\text { [accuracy and representation } \\
\text { of viewpoints] of } \\
\text { the Commercial Television } \\
\text { Industry Code of Practice } \\
2010\end{array}$ \\
\hline TCN & Today & $\begin{array}{l}\text { Inappropriate depictions of } \\
\text { nudity and sexual behaviour }\end{array}$ & $\begin{array}{l}\text { No breach of clause } 2.4 .1 \\
\text { [Exemption for news, current } \\
\text { affairs and broadcasts of }\end{array}$ \\
\hline
\end{tabular}




\begin{tabular}{|c|c|c|c|}
\hline Call Sign & $\begin{array}{l}\text { Program } \\
\text { Name }\end{array}$ & Description & Outcome \\
\hline & & & sporting events] \\
\hline QTQ & A Current Affair & $\begin{array}{l}\text { Privacy in footage of theme } \\
\text { park }\end{array}$ & $\begin{array}{l}\text { No breach of clause } 4.3 .5 \text { of } \\
\text { the Commercial Television } \\
\text { Industry Code of Practice } \\
2010\end{array}$ \\
\hline SAS & $\begin{array}{l}\text { Channel Seven } \\
\text { News }\end{array}$ & $\begin{array}{l}\text { Breach of licence arising from } \\
\text { alleged tobacco advertisement }\end{array}$ & $\begin{array}{l}\text { No breach of parargraph } \\
7(1)(\text { a) of Schedule } 2 \text { to } \\
\text { the Broadcasting Services Act } \\
1992 \text { (Cth) } \\
\text { advertising] }\end{array}$ \\
\hline ATV & $\begin{array}{l}\text { Advertisement- } \\
\text { Clever Smoke }\end{array}$ & $\begin{array}{ll}\text { Broadcast } & \text { tobacco } \\
\text { advertisement } & \end{array}$ & $\begin{array}{l}\text { No breach of paragraph } \\
7(1) \text { [a] of Schedule } 2 \text { to } \\
\text { the Broadcasting Services Act } \\
1992 \text { (Cth)[tobacco } \\
\text { advertising] }\end{array}$ \\
\hline QTQ Qld & A Current Affair & $\begin{array}{l}\text { Accurate presentation of } \\
\text { factual material. Invasion of } \\
\text { privacy. } \\
\text { complaints. }\end{array}$ & $\begin{array}{l}\begin{array}{l}\text { Breach of clause } \\
\text { [accuracy] }\end{array} \\
\begin{array}{l}\text { Breach of clause } \\
\text { [privacy] }\end{array} \\
\begin{array}{l}\text { No breach of clause } \\
7.9 \text { [complaint handling] }\end{array}\end{array}$ \\
\hline $\begin{array}{l}\text { ATN } \\
\text { Sydney }\end{array}$ & Today Tonight & $\begin{array}{l}\text { Misleading dramatisations, } \\
\text { inaccuracies, lack of } \\
\text { sensitivity in interview with } \\
\text { bereaved relative, unfair } \\
\text { identification of an individual, } \\
\text { gratuitous focus on religion } \\
\text { and provocation of dislike, } \\
\text { contempt and ridicule on } \\
\text { grounds of religion in segment } \\
\text { 'The Death of a Believer'. } \\
\text { Inaccuracies in promotion for } \\
\text { the segment. }\end{array}$ & $\begin{array}{l}\text { No breach of clause } 1.9 .6 \\
\text { [provoke or perpetuate intense } \\
\text { dislike, serious contempt or } \\
\text { severe ridicule on the grounds } \\
\text { of religion]; } \\
\text { Breach of clause } 4.3 .1 \text { [factual } \\
\text { accuracy]; } \\
\text { No breach of clause } 4.3 .1 \text { [fair } \\
\text { representation of viewpoints]; } \\
\text { No breach of clause } 4.3 .6 \\
\text { [sensitivity in broadcasting } \\
\text { images of or interviews with } \\
\text { bereaved relatives]; } \\
\text { No breach of clause } 4.3 .7 \\
\text { [unfairly identifying a single } \\
\text { person when commenting on } \\
\text { the behaviour of a group]; } \\
\text { No breach of clause } 4.3 .10 \\
\text { [portray group of persons in a } \\
\text { negative light by placing } \\
\text { gratuitous emphasis } \\
\text { religion]; and } \\
\text { Breach of clause } 4.5 \text { [factual } \\
\text { accuracy of news and current } \\
\text { affairs promotions] }\end{array}$ \\
\hline SAS & Seven News & $\begin{array}{l}\text { Gratuitous emphasis on Irish } \\
\text { nationality in report on a court }\end{array}$ & $\begin{array}{l}\text { No breach of clause } 4.3 .10 \\
\text { [gratuitous emphasis on } \\
\text { national or ethnic origin] of }\end{array}$ \\
\hline
\end{tabular}




\begin{tabular}{|c|c|c|c|}
\hline Call Sign & $\begin{array}{l}\text { Program } \\
\text { Name }\end{array}$ & Description & Outcome \\
\hline & & case & $\begin{array}{l}\text { the Commercial Television } \\
\text { Industry Code of Practice } \\
2010\end{array}$ \\
\hline $\begin{array}{c}\text { HSV } \\
\text { Melbourne }\end{array}$ & Today Tonight & $\begin{array}{l}\text { Accuracy, } \quad \text { gratuitous } \\
\text { emphasis, incite hatred } \\
\text { concerning Council proposals }\end{array}$ & $\begin{array}{l}\text { No breach of clauses 1.9.6, } \\
4.3 .1,4.3 .10 \text { or } 4.3 .11 \text { of } \\
\text { the Commercial Television } \\
\text { Industry Code of Practice } \\
2010\end{array}$ \\
\hline $\begin{array}{c}\text { GTV } \\
\text { Melbourne }\end{array}$ & A Current Affair & $\begin{array}{l}\text { Accuracy in segment about } \\
\text { administrator of Facebook site }\end{array}$ & $\begin{array}{l}\text { No breach of clause } 4.3 .1 \text { of } \\
\text { the Commercial } \\
\text { Industry Colevision } \\
2010\end{array}$ \\
\hline $\begin{array}{c}\text { TNT } \\
\text { Tasmania }\end{array}$ & Today Tonight & $\begin{array}{l}\text { Privacy, accuracy and } \\
\text { viewpoints }\end{array}$ & $\begin{array}{l}\text { Breach of clause 4.3.5. No } \\
\text { breach of clauses } 4.3 .1 \text { and } \\
4.3 .5 .2 \text { of the Commercial } \\
\text { Television Industry Code of } \\
\text { Practice } 2010\end{array}$ \\
\hline $\begin{array}{l}\text { TCN } \\
\text { Sydney }\end{array}$ & A Current Affair & $\begin{array}{l}\text { Accuracy; ridicule; and } \\
\text { portrayal in negative light in } \\
\text { item about tax exemptions } \\
\text { given to religious } \\
\text { organisations in Australia }\end{array}$ & $\begin{array}{l}\text { No breach of clauses } 1.9 .6 \text {, } \\
4.3 .1 \text { or } 4.3 .5 \text { of } \\
\text { the Commercial } \\
\text { Industry Codevision } \\
2010\end{array}$ \\
\hline $\begin{array}{l}\text { QTQ } \\
\text { Brisbane }\end{array}$ & A Current Affair & $\begin{array}{l}\text { Broadcast factual material } \\
\text { accurately and fair } \\
\text { representation of viewpoints in } \\
\text { story about auto mechanics }\end{array}$ & $\begin{array}{l}\text { No breach of } 4.3 .1 \text { of } \\
\text { the Commercial Television } \\
\text { Industry Code of Practice } \\
2010\end{array}$ \\
\hline $\begin{array}{c}\text { GTV } \\
\text { Melbourne }\end{array}$ & A Current Affair & Privacy of a child & $\begin{array}{l}\text { No breach of clauses } 4.3 .5 \text { and } \\
4.3 .5 .2 \text { of the Commercial } \\
\text { Television Industry Code of } \\
\text { Practice } 2010\end{array}$ \\
\hline $\begin{array}{l}\text { TCN } \\
\text { Sydney }\end{array}$ & A Current Affair & $\begin{array}{l}\text { Accuracy, representation of } \\
\text { viewpoints and invasion of } \\
\text { privacy in report about a legal } \\
\text { dispute }\end{array}$ & $\begin{array}{l}\text { No breach of clauses } 4.3 .1 \text { or } \\
4.3 .5 \text { of the Commercial } \\
\text { Television Industry Code of } \\
\text { Practice } 2010\end{array}$ \\
\hline $\begin{array}{l}\text { CTC - } \\
\text { Regional } \\
\text { NSW }\end{array}$ & $\begin{array}{l}\text { Advertisement } \\
\text { for the Lithgow } \\
\text { Valley Plaza }\end{array}$ & Tobacco advertising & $\begin{array}{l}\text { No breach of paragraph } \\
7(1) \text { (a) of Schedule } 2 \text { to } \\
\text { the Broadcasting Services Act }\end{array}$ \\
\hline
\end{tabular}




\begin{tabular}{|c|c|c|c|}
\hline Call Sign & $\begin{array}{l}\text { Program } \\
\text { Name }\end{array}$ & Description & Outcome \\
\hline & & & 1992 \\
\hline STW 9 & $\begin{array}{l}\text { Nine News, } \\
\text { Today }\end{array}$ & $\begin{array}{l}\text { Accuracy and public panic } \\
\text { issues in report about an } \\
\text { illness following vaccination }\end{array}$ & $\begin{array}{l}\text { No breach of clauses } 4.3 .1 \text {, } \\
4.3 .2 \text { or } 4.5 \text { of the Commercial } \\
\text { Television Industry Code of } \\
\text { Practice } 2010\end{array}$ \\
\hline VTV & $\begin{array}{l}\text { Nine News } \\
\text { Update }\end{array}$ & $\begin{array}{llr}\text { Clause } & 4.3 .8 & \text { of } \\
\text { the Commercial } & \text { Television } \\
\text { Industry } & \text { Code of } & \text { Practice } \\
2010 & & \end{array}$ & $\begin{array}{lr}\text { Breach of clause } & 4.3 .8 \\
\text { [identification } & \text { before } \\
\text { notification by authorities] }\end{array}$ \\
\hline SAS & Today Tonight & $\begin{array}{l}\text { Accuracy, viewpoints and } \\
\text { privacy in a report about a } \\
\text { resort complex }\end{array}$ & $\begin{array}{l}\text { No breach of clauses } 4.3 .1 \text {, } \\
4.3 .5 \text { and } 4.3 .5 .2 \text { of } \\
\text { the Commercial } \\
\text { Industry Colevision of Practice } \\
2010 .\end{array}$ \\
\hline ATN & Seven News & $\begin{array}{l}\text { Accuracy, fairness and } \\
\text { impartiality }\end{array}$ & $\begin{array}{l}\text { No breach of } 4.4 .1 \text { and } 4.4 .1 \\
\text { of Code }\end{array}$ \\
\hline TCN-9 & A Current Affair & $\begin{array}{l}\text { Proscribed matter and } \\
\text { accuracy }\end{array}$ & $\begin{array}{l}\text { No breach of clause } 1.9 .6 \text { and } \\
4.3 .1 \text { of the Commercial } \\
\text { Television Industry Code of } \\
\text { Practice } 2010\end{array}$ \\
\hline $\begin{array}{l}\text { Channel } 9 \\
\text { South } \\
\text { Australia } \\
\text { Pty Ltd }\end{array}$ & $\begin{array}{l}\text { Nine News } \\
\text { update/program } \\
\text { promotion }\end{array}$ & $\begin{array}{l}\text { Classification and promotions } \\
\text { for news }\end{array}$ & $\begin{array}{l}\text { No breach of clause } 2.4 \\
\text { [classification] } \\
\text { No breach of clause } 3.13 \\
\text { [promotions for news] of } \\
\text { the Commercial Television } \\
\text { Industry Code of Practice } \\
2010\end{array}$ \\
\hline TCN-9 & Weekend Today & $\begin{array}{l}\text { Accuracy/viewpoints and } \\
\text { proscribed material in relation } \\
\text { to a current affairs segment on } \\
\text { guns }\end{array}$ & $\begin{array}{l}\text { No breach of clause } 1.9 .1 \\
\text { [proscribed } \\
\text { No breach of clause } 4.3 .1 \\
\text { [accuracy] of the Commercial } \\
\text { Television Industry Code of } \\
\text { Practice } \\
\text { ren }\end{array}$ \\
\hline $\begin{array}{l}\text { Ten and } \\
\text { One }\end{array}$ & $\begin{array}{l}\text { Advertisement - } \\
\text { Vaporfresh e- }\end{array}$ & Tobacco advertisement & $\begin{array}{l}\text { No breach of clause } 7(1)(a) \text { of } \\
\text { Schedule } 2\end{array}$ \\
\hline
\end{tabular}




\begin{tabular}{|c|c|c|c|}
\hline Call Sign & $\begin{array}{l}\text { Program } \\
\text { Name }\end{array}$ & Description & Outcome \\
\hline & cigarette & & 1992 \\
\hline Seven & Today Tonight & $\begin{array}{l}\text { Accuracy, privacy, unfair } \\
\text { identification and correction of } \\
\text { significant errors in a current } \\
\text { affairs segment about the SA } \\
\text { family day care industry }\end{array}$ & $\begin{array}{l}\text { No breach of clauses } 4.3 .1 \\
\text { [accuracy], } 4.3 .5 \text { [privacy], } \\
4.3 .7 \text { [unfair identification] } \\
\text { and } 4.3 .11 \text { [correction of } \\
\text { significant errors] of } \\
\text { the Commercial Television } \\
\text { Industry Code of Practice } \\
2010\end{array}$ \\
\hline Seven & Today Tonight & $\begin{array}{l}\text { Accuracy, privacy, unfair } \\
\text { identification and correction of } \\
\text { significant errors in a current } \\
\text { affairs segment about the SA } \\
\text { family day care industry }\end{array}$ & $\begin{array}{l}\text { No breach of clauses } 4.3 .1 \\
\text { [accuracy], 4.3.5 [privacy], } \\
4.3 .7 \text { [unfair identification] } \\
\text { and } 4.3 .11 \text { [correction of } \\
\text { significant errors] of } \\
\text { the Commercial Television } \\
\text { Industry Code of Practice } \\
2010\end{array}$ \\
\hline Tem & $\begin{array}{c}\text { Ten Eyewitness } \\
\text { News }\end{array}$ & $\begin{array}{l}\text { Accuracy and privacy in a } \\
\text { news segment reporting on an } \\
\text { assault. }\end{array}$ & $\begin{array}{l}\text { Breach of clauses } 4.3 .1 \\
\text { [accuracy] and } 4.3 .5 \text { [privacy] } \\
\text { of the Commercial Television } \\
\text { Industry Code of Practice } \\
2010\end{array}$ \\
\hline 7TWO & $\begin{array}{l}\text { Program } \\
\text { promotions for } \\
\text { the mini-series } \\
\text { Catching Milat }\end{array}$ & $\begin{array}{l}\text { Investigation into a complaint } \\
\text { that the two program } \\
\text { promotions were unsuitable } \\
\text { for broadcast within the G } \\
\text { classified program, Better } \\
\text { Homes and Gardens. }\end{array}$ & $\begin{array}{l}\text { Breach of clause } 2.4 \\
\text { [classification of other } \\
\text { material] and clause } 3.8 \\
\text { [restrictions in } \mathrm{G} \text { viewing } \\
\text { periods and certain other } \mathrm{G} \\
\text { programs] of Commercial } \\
\text { Television Industry Code of } \\
\text { Practice 2010 }\end{array}$ \\
\hline Seven & $\begin{array}{l}\text { Catching } \\
\text { Milat(mini- } \\
\text { series) }\end{array}$ & $\begin{array}{l}\text { Investigation into a complaint } \\
\text { that each part of the program } \\
\text { was incorrectly classified } \\
\text { Mature (M). }\end{array}$ & $\begin{array}{l}\text { No breach of clause } 2.4 \\
\text { [classification of other } \\
\text { material] of Commercial } \\
\text { Television Industry Code of } \\
\text { Practice } 2010\end{array}$ \\
\hline Nine & A Current Affair & $\begin{array}{l}\text { Religious vilification, privacy } \\
\text { and gratuitous emphasis on } \\
\text { religion in a segment about } \\
\text { private vocational education } \\
\text { and training (VET) providers } \\
\text { and alleged links to the }\end{array}$ & $\begin{array}{l}\text { No breach of clauses } 1.9 .6 \\
\text { [proscribed material } \\
\text { religious vilification], } 4.3 .5 \\
\text { [privacy] and } 4.3 .10 \\
\text { (gratuitous emphasis on } \\
\text { religion) of the Commercial } \\
\text { Television Industry Code of }\end{array}$ \\
\hline
\end{tabular}




\begin{tabular}{|c|c|l|l|}
\hline Call Sign & $\begin{array}{c}\text { Program } \\
\text { Name }\end{array}$ & \multicolumn{1}{c|}{ Description } & \multicolumn{1}{c|}{ Outcome } \\
\hline 7mate & $\begin{array}{c}\text { World's Craziest } \\
\text { Fools }\end{array}$ & $\begin{array}{l}\text { Investigation into a complaint } \\
\text { that a segment of the program } \\
\text { was unsuitable for broadcast in } \\
\text { a PG classified program. }\end{array}$ & $\begin{array}{l}\text { No breach of clause 2.4 } \\
\text { classification of other } \\
\text { material] of the Commercial } \\
\text { Television Industry Code of } \\
\text { Practice 2010 }\end{array}$ \\
\hline
\end{tabular}




\section{Anexo II - Tabela de casos Alemanha}

\begin{tabular}{|c|c|c|c|c|}
\hline Questão envolvida & Esfera & Estado & Decisão & $\begin{array}{l}\text { Decisão } \\
\text { autoridade } \\
\text { reguladora }\end{array}$ \\
\hline $\begin{array}{l}\text { Propaganda vinculada à } \\
\text { programação. }\end{array}$ & $\begin{array}{c}\text { Corte } \\
\text { Administrativa }\end{array}$ & $\begin{array}{l}\text { Renânia- } \\
\text { Palatinado }\end{array}$ & $\begin{array}{l}\text { Condenação } \\
\text { emissora Sat } \\
\text { multa }\end{array}$ & Mantida \\
\hline $\begin{array}{l}\text { Transmissão } \\
\text { conteúdo obtido de } \\
\text { forma ilegal vs. } \\
\text { liberdade de expressão } \\
\text { da emissora. }\end{array}$ & Suprema Corte & Federal & 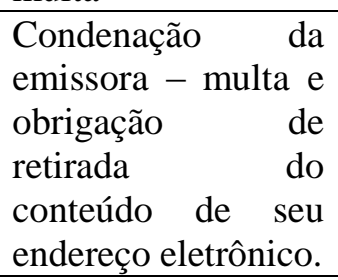 & Mantida \\
\hline $\begin{array}{l}\text { Violação da lei de } \\
\text { proteção aos menores e } \\
\text { violação ao princípio da } \\
\text { dignidade humana. }\end{array}$ & $\begin{array}{c}\text { Corte } \\
\text { Administrativa }\end{array}$ & Hanover & $\begin{array}{l}\text { Condenação } \\
\text { emissora } \\
\text { multa }\end{array}$ & Mantida \\
\hline $\begin{array}{l}\text { Transmissão de conteú } \\
\text { Ndo obtido de forma } \\
\text { ilegal vs. liberdade de } \\
\text { expressão da emissora. }\end{array}$ & Judiciário & $\begin{array}{l}\text { Renânia do } \\
\text { Norte- } \\
\text { Vestefália }\end{array}$ & $\begin{array}{l}\text { Emissora não } \\
\text { condenada. }\end{array}$ & Não houve \\
\hline $\begin{array}{l}\text { Propaganda vinculada à } \\
\text { programação. }\end{array}$ & $\begin{array}{c}\text { Corte } \\
\text { Administrativa }\end{array}$ & Federal & $\begin{array}{l}\text { Condenação da } \\
\text { emissora } \\
\text { ProSieben: multa }\end{array}$ & Mantida \\
\hline $\begin{array}{l}\text { Violação da lei de } \\
\text { proteção aos menores. }\end{array}$ & $\begin{array}{c}\text { Corte } \\
\text { Administrativa }\end{array}$ & Baviera & $\begin{array}{lr}\text { Condenação } & \text { da } \\
\text { emissora } & M T V \\
\text { music channel: } \\
\text { restrição de horário } \\
(23 \mathrm{~h}-6 \mathrm{~h}) \text {. }\end{array}$ & Mantida \\
\hline $\begin{array}{ll}\text { Propagação } & \text { de } \\
\text { violência/incitação } & \text { ao } \\
\text { ódio. } & \end{array}$ & $\begin{array}{l}\text { Judiciário - } \\
\text { Suprema Corte }\end{array}$ & Federal & 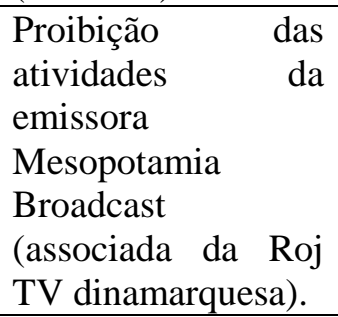 & Mantida \\
\hline $\begin{array}{l}\text { Violação da lei de } \\
\text { proteção aos menores. }\end{array}$ & $\begin{array}{c}\text { Corte } \\
\text { Administrativa }\end{array}$ & Baviera & $\begin{array}{lr}\text { Condenação } & \text { da } \\
\text { emissora MTV } \\
\text { music channel: } \\
\text { restrição de horário } \\
(23 \mathrm{~h}-6 \mathrm{~h}) \text {. } \\
\end{array}$ & Mantida \\
\hline $\begin{array}{l}\text { Violação de direito da } \\
\text { personalidade, imagem e } \\
\text { confidencialidade. }\end{array}$ & Judiciário & Düsseldorf & $\begin{array}{lr}\text { Proibição } & \text { da } \\
\text { emissora } & \text { RTL } \\
\text { transmitir } & \text { as } \\
\text { imagens } & \text { e } \\
\text { gravações } & \text { feitas } \\
\text { com médico. } & \\
\end{array}$ & Mantida \\
\hline $\begin{array}{l}\text { Violação da lei de } \\
\text { proteção aos menores. }\end{array}$ & $\begin{array}{c}\text { Corte } \\
\text { Administrativa }\end{array}$ & Berlim & $\begin{array}{l}\text { Condenação da } \\
\text { emissora } \\
\text { ProSieben: restrição } \\
\text { de horário (23h - } \\
6 \mathrm{~h}) .\end{array}$ & Mantida \\
\hline
\end{tabular}




\begin{tabular}{|c|c|c|c|c|}
\hline Questão envolvida & Esfera & Estado & Decisão & $\begin{array}{l}\text { Decisão } \\
\text { autoridade } \\
\text { reguladora }\end{array}$ \\
\hline $\begin{array}{l}\text { Propaganda vinculada à } \\
\text { programação. }\end{array}$ & $\begin{array}{c}\text { Corte } \\
\text { Administrativa }\end{array}$ & $\begin{array}{l}\text { Renânia- } \\
\text { Palatinado }\end{array}$ & 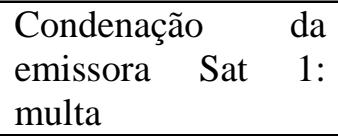 & Mantida \\
\hline $\begin{array}{l}\text { Violação do princípio da } \\
\text { dignidade humana. }\end{array}$ & $\begin{array}{c}\text { Corte } \\
\text { Administrativa }\end{array}$ & Baixa Saxônia & $\begin{array}{l}\text { Condenação da } \\
\text { emissora RTL }- \\
\text { multa e proibição } \\
\text { de repetição de } \\
\text { programa com } \\
\text { mesmo teor }\end{array}$ & Mantida \\
\hline $\begin{array}{l}\text { Violação da lei de } \\
\text { proteção aos menores. }\end{array}$ & $\begin{array}{c}\text { Corte } \\
\text { Administrativa }\end{array}$ & Baixa Saxônia & $\begin{array}{l}\text { Condenação da } \\
\text { emissora RTL - } \\
\text { multa e proibição } \\
\text { de repetição de } \\
\text { programa com } \\
\text { mesmo teor }\end{array}$ & Mantida \\
\hline $\begin{array}{l}\text { Violação da dignidade } \\
\text { humana }\end{array}$ & $\begin{array}{c}\text { Corte } \\
\text { Administrativa }\end{array}$ & Hanover & $\begin{array}{lr}\text { Condenação } & \text { da } \\
\text { emissora } & \text { RTL: } \\
\text { multa } & \\
\end{array}$ & Mantida \\
\hline $\begin{array}{l}\text { Violação da lei de } \\
\text { proteção aos menores. }\end{array}$ & $\begin{array}{c}\text { Corte } \\
\text { Administrativa }\end{array}$ & Baviera & 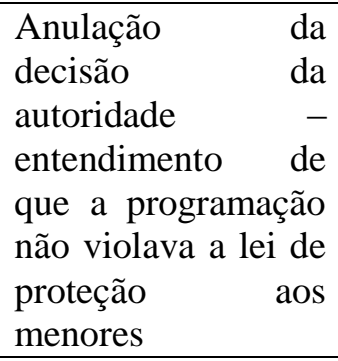 & Reformada \\
\hline $\begin{array}{l}\text { Violação do Legal } \\
\text { Advice Act - programa } \\
\text { se envolveu em questões } \\
\text { legais em nome de } \\
\text { terceiros. }\end{array}$ & $\begin{array}{c}\text { Judiciário - } \\
\text { Suprema Corte }\end{array}$ & Federal & $\begin{array}{l}\text { Anulação da } \\
\text { decisão do tribunal } \\
\text { e remessa dos autos } \\
\text { para nova decisão. }\end{array}$ & Não houve \\
\hline $\begin{array}{l}\text { Discussão acerca do } \\
\text { tempo de } \\
\text { para } \\
\text { independentes. }\end{array}$ & $\begin{array}{c}\text { Corte } \\
\text { Administrativa }\end{array}$ & Baixa Saxônia & 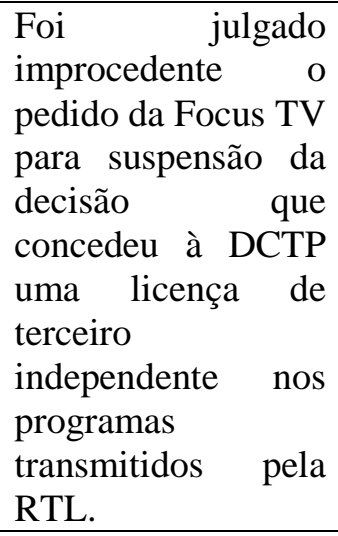 & Mantida \\
\hline $\begin{array}{l}\text { Violação do Legal } \\
\text { Advice Act - programa } \\
\text { se envolveu em questões } \\
\text { legais em nome de } \\
\text { terceiros. }\end{array}$ & $\begin{array}{c}\text { Judiciário - } \\
\text { Suprema Corte }\end{array}$ & Federal & $\begin{array}{l}\text { Suprema } r \text { corte } \\
\text { entendeu que as } \\
\text { emissoras de TV } \\
\text { não infringiram a } \\
\text { lei, pois a essência } \\
\text { dos programas } \\
\text { transmitidos não era } \\
\text { a interferência em } \\
\text { casos individuais, } \\
\text { mas sim a }\end{array}$ & Não houve \\
\hline
\end{tabular}




\begin{tabular}{|c|c|c|c|c|}
\hline Questão envolvida & Esfera & Estado & Decisão & $\begin{array}{l}\text { Decisão } \\
\text { autoridade } \\
\text { reguladora }\end{array}$ \\
\hline & & & $\begin{array}{lr}\text { transmissão } & \text { de } \\
\text { informações } & \text { ao } \\
\text { público acerca } & \text { de } \\
\text { problemas jurídicos } \\
\text { típicos } \\
\text { recorrentes. }\end{array}$ & \\
\hline Direito de resposta. & Judiciário & Stuttgart & $\begin{array}{l}\text { Corte entendeu que } \\
\text { não poderia ser } \\
\text { dado o direito de } \\
\text { resposta no caso em } \\
\text { questão, uma vez } \\
\text { que o pedido deve } \\
\text { ser feito em no } \\
\text { máximo } 2 \text { semanas } \\
\text { após a transmissão } \\
\text { do programa que se } \\
\text { pretende responder. }\end{array}$ & Não houve \\
\hline $\begin{array}{ll}\text { Disseminação } & \text { de } \\
\text { material extremista. } & \end{array}$ & $\begin{array}{l}\text { Administrativa - } \\
\text { autoridade }\end{array}$ & Berlim & $\begin{array}{l}\text { Rádio Germânia } \\
\text { banida } \\
\text { permanentemente } \\
\text { do "Berlin open } \\
\text { channel" } \\
\text { divulgar conteúdo } \\
\text { difamatório sobre o } \\
\text { falecido presidente } \\
\text { do } \\
\text { Central Jonselho } \\
\text { alemão, além do } \\
\text { programa conter } \\
\text { traços agressivos } \\
\text { antissemitas. }\end{array}$ & $\begin{array}{c}\text { Não houve } \\
\text { apelação - } \\
\text { decisão } \\
\text { mantida. }\end{array}$ \\
\hline
\end{tabular}




\section{Anexo III - Reclamação à emissora - Austrália}

\section{E-mail enviado à ACMA em 13/08/2016}

On 10 August 2016, the Nine Network, while broadcasting the program A Current Affair, has shown Brady Halls putting himself into a tub cooled at minus 140 degrees Celsius. The program aimed to present the Whole-body cryotherapy, a method of cooling, and the segment included sentences as "Walt Disney has been frozen in a similar way" and that the cryotherap "oxygenates the blood and washes the toxins from the blood". Besides that, the program put a subtitle saying "Freeze your weight".

One might allegate that the channel breached clause 4.3.1. of the Commercial Television Industry Code of Practice 2010, which establishes that licensees must broadcast factual material accurately and represent viewpoints fairly. The broadcaster did not even mentioned the risks of Whole-body cryotherapy and the segment could suggest to ordinary reasonable viewers that the method really has effects on losing weight and has therapeutic and medicinal purposes.

As a matter of fact, researchers from Queensland University of Technology and The University of Queensland recently produced evidence showing that post-workout ice baths are not only ineffective for reducing muscle soreness, but they can also hinder muscle development. Findings showed that satellite cells - skeletal muscle stem cells responsible for muscle regeneration - were "blunted" for up to two days after exercise and a post-workout ice bath. The research also identified a reduction of muscle blood flow as a mechanism that may hinder long-term muscle gains. Hypothermia is possible as well.

There is no scientific evidence whatsoever of any kind that it has a lasting effect on circulation, nervous function, depression or any other health issue. The program claimed a myriad of health benefits, althought provided no actual evidence, not even minimal anecdotal evidence.

The segment promoted an uncritical, positive attitude among people towards the Whole-body cryotherapy and it suggested that social acceptance was primarily dependent on outward appearance. Negative consequences and side effects of the therapy were not shown. 


\section{Anexo IV - Resposta da emissora - Austrália}

\section{$\because$ :Nine \\ entertainment co.}

15 September 2016

Ms Carolina Silveira

By email: carolinamcsilveira@gmail.com

Dear Ms Silveira,

We write in response to your online complaint dated 17 August 2016 in relation to a news report during the program A Current Affair broadcast on 10 August 2016 (the Report).

We have reviewed the Report specified in your complaint in order to assess your concerns. Your complaint alleges that the substance of the Report with respect to whole-body cryotherapy was incorrect.

As a commercial free to air television broadcaster, the content Nine broadcasts is regulated by the Commercial Television Industry Code of Practice (the Code). The Code states that:

3.3.1 In broadcasting a news or Current Affairs program, a licensee must present factual material accurately and ensure viewpoints included in the Program are not misrepresented.

We have reviewed the Report and confirm that it has been prepared in accordance with the Code The Report was in relation to the increasing popularity of whole-body cryotherapy in the United States and Australia. It featured a facility offering cryotherapy in Sydney called Cryo Fitness. In order to demonstrate what is involved with this treatment, the reporter tested the cryosauna available at Cryo Fitness and his experience was included in the Report for both a humourous and light-hearted effect. We understand from your complaint that you believe that the Report made incorrect representations about the safety and efficacy of cryotherapy.

In order to consider your concerns, we have reviewed the Report the subject of your complaint. We note that while the Report included personal anecdotes from some people in relation to how this treatment has helped them, the Report did not make any claims about the safety of cryotherapy and its effectiveness in treating certain conditions. Viewers would have understood that the viewpoints expressed by these people were their opinions based on their personal experience and not unequivocal representations about the efficacy of cryotherapy. Furthermore, the Report overall made it clear that any potential benefits of cryotherapy that were reported on were simply claims and assertions rather than substantiated facts. This can be seen by the statements "The new procedure that claims to burn off calories within minutes" and "I'm standing in minus 145 degrees Celsius, in nothing but my socks and undies, and Peter Watson [of Cryo Fitness] reckons l'm doing myself a world of good ${ }^{n}$. We further note that the subtitle that you have noted in your complaint was "Freeze Your Weight Off?" which is a question rather than a statement of fact. We consider that the effect on viewers of any statements promoting the potential health benefits of cryotherapy were adequately balanced by these statements set out above and the overall tone and context of the Report. Therefore, Nine maintains that the information provided was accurate and viewpoints fairly represented, in compliance with the Code.

www.nineentertainment.com.au

PO Box 27, Willoughby NSW 2068 P .61 $299069999 \quad F \cdot 61292828828$ ABN 60122203892 


\section{:̊:Nine}

In addition, the Code does not stipulate the level of forensic analysis required for issues that may be presented in news and current affairs programs. In relation to current affairs in particular, broadcasters retain an editorial discretion in relation to the way in which particular issues are discussed and analysed, subject to the requirement that the information that is provided is accurate and any viewpoints provided are fairly represented. In this case, the principal purpose of the Report was to inform viewers about the increasing trend and popularity of cryotherapy and to provide a light-hearted personal account from the reporter of his experience using this treatment. The Report was not intended to provide a comprehensive analysis of the safety and efficacy of cryotherapy, and its light-hearted tone would be understood by most viewers in this capacity. Accordingly, we do not believe that the scientific and medical research into cryotherapy were matters required to be discussed given the context and nature of the Report.

We appreciate you taking the time to provide your feedback on the Report, but for the reasons above, Nine does not consider that there has been any contravention of the Code. We hope this information helps to answer your concerns, however if you are not satisfied with this response, you may refer the matter to the Australian Communications and Media Authority.

Yours sincerely

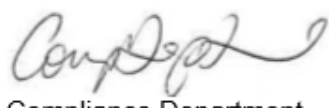

Compliance Department

Nine Network Australia 


\section{Anexo V - Resposta da ACMA}

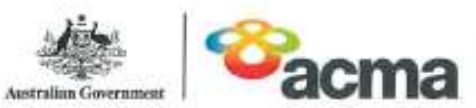

7 October 2016

Ms Carolina Silveira

By email: carolinamcsilveira@gmail.com

ACMA reterence: BM-1679

nwmacmagova

ACMA reference: BM-1679

Dear Ms Silveira,

Your complaint about A Current Affair broadcast on Nine on 10 August 2016

Thank you for your complaint about the above program, referred to in your correspondence received 21 September 2016.

The Australian Communications and Media Authority (the ACMA) considers all complaints to be important and your concerns have been logged in our database to help identify potential recurring or systemic compliance issues with legislation, Codes of Practice and Standards.

When deciding whether to investigate a particular matter, the ACMA considers a range of public interest factors including the specifics and/or merits of the matter, the nature and seriousness of the issue raised, the matter's potential to affect the community at large and its priority in relation to other matters of public interest.

We acknowledge that this matter has given you cause for concern, however, the ACMA has decided not to proceed with an investigation into your complaint because:

- The broadcast narrative contained a degree of scepticism about the efficacy of the treatment. Any comments in support for cryotherapy were presented as either personal experience or as a claim of the cryotherapy industry, and not unequivocal fact.

- While Nine journalist Brady Halls presented the story in a light hearted tone, he alluded to concerns about his personal safety while undergoing the procedure.

- Under the Commercial Television Industry Code of Practice 2015 (the Code), Current Affairs programs are not required to be impartial and may take a particular stance on issues. However they must present factual material accurately and ensure material viewpoints are not misrepresented.

- From our initial assessment of the broadcast, we cannot see any evidence of factual inaccuracy or misrepresentation of material viewpoints in the program.

Given this, it is unlikely that an investigation would result in a breach finding against the Code. 


\section{Anexo VI - Troca de e-mails - Alemanha}

De: Programmbeschwerde <info@ programmbeschwerde.de>

Data: 16 de novembro de 2015 07:54:00 BRST

Para: "renatalea195@gmail.com" <renataleal95@gmail.com>

Assunto: Pro 7: Programmbeschwerde

Sehr geehrte Frau Leal,

vielen Dank für Ihr Interesse an unserem Beschwerdeportal und den Hinweis auf die Ausstrahlung der Sendung „Wild Island“ im Programm von Pro 7 am 12.11.2015. Ihr Anliegen leite ich mit gleichem Schreiben weiter an die für die Aufsicht über den Sender zuständige Medienanstalt Berlin-Brandenburg (MABB).

Mit freundlichen Grüßen

Im Auftrag

Helga Schwarz

Abteilung IV, Jugendschutz,

Programm und Medienförderung

Landesmedienanstalt Saarland

Anstalt des Öffentlichen Rechts

Nell-Breuning-Allee 6

66115 Saarbrücken

Tel: 0681/38988-45

E-Mail: schwarz@lmsaar.de

Internet: www.LMSaar.de

Direktor: Dr. Gerd Bauer

Vorsitzender des Medienrates: Prof. Dr. Stephan Ory

Sitz der Anstalt: Saarbrücken

Diese E-Mail kann vertrauliche Informationen enthalten. Sollten Sie diese E-Mail irrtümlich erhalten haben, bitte ich Sie, von einer Vervielfältigung oder Weitergabe der E-Mail abzusehen. Vielen Dank.

Von: Renata Leal [mailto:renataleal95@gmail.com]

Gesendet: Freitag, 13. November 2015 16:59

An: Programmbeschwerde <info@ programmbeschwerde.de>

Betreff: Programmbeschwerde Kontakt:

Beschwerde:

Gewinnspielregeln

\section{Programm:}

Wild Island - Das pure Überleben

Name der Sendung:

die inselgefahren

Datum: 12/11/2015

Uhrzeit: 22:30

\section{Bemerkung:}

